\title{
Distribution of Selected Nitrogen Compounds in Ground Water and the Unsaturated Zone, Superior-Hardy Special Protection Area, Nuckolls County, Nebraska, 1991-93
}

\section{U.S. GEOLOGICAL SURVEY}

Water-Resources Investigations Report 96-4239

\section{Prepared in cooperation with the}

NEBRASKA DEPARTMENT OF ENVIRONMENTAL QUALITY; LOWER REPUBLICAN NATURAL RESOURCES DISTRICT; LITTLE BLUE NATURAL RESOURCES DISTRICT; and the CONSERVATION AND SURVEY DIVISION, UNIVERSITY OF NEBRASKA-LINCOLN

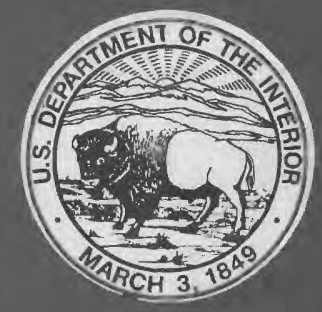




\section{Distribution of Selected Nitrogen Compounds in Ground Water and the Unsaturated Zone, Superior-Hardy Special Protection Area, Nuckolls County, Nebraska, 1991-93}

By ABRAHAM H. CHEN

\section{U.S. GEOLOGICAL SURVEY}

Water-Resources Investigations Report 96-4239

Prepared in cooperation with the NEBRASKA DEPARTMENT OF ENVIRONMENTAL QUALITY; LOWER REPUBLICAN NATURAL RESOURCES DISTRICT; LITTLE BLUE NATURAL RESOURCES DISTRICT; and the CONSERVATION AND SURVEY DIVISION, UNIVERSITY OF NEBRASKA-LINCOLN






\title{
U.S. DEPARTMENT OF THE INTERIOR
}

BRUCE BABBITT, Secretary

\author{
U.S. GEOLOGICAL SURVEY
}

Gordon P. Eaton, Director

The use of firm, trade, and brand names in this report is for identification purposes only and does not constitute endorsement by the U.S. Geological Survey.

For additional information write to:

Copies of this report can be purchased from:

District Chief

U.S. Geological Survey

Room 406 Federal Building

100 Centennial Mall North

Lincoln, NE 68508
U.S. Geological Survey

Branch of Information Services

Box 25286

Denver, CO 80225-0286 


\section{CONTENTS}

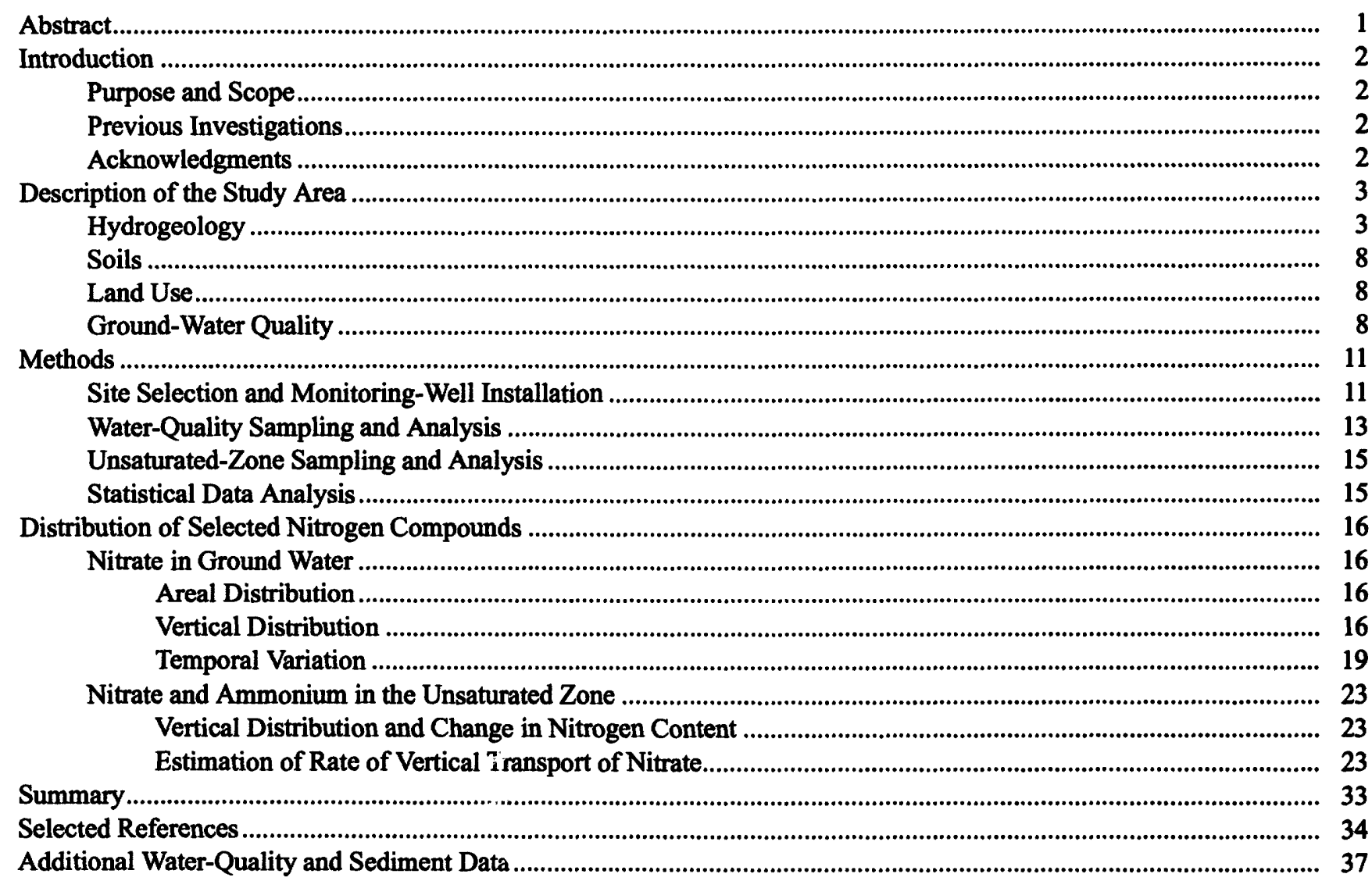

\section{FIGURES}

1-7. Maps showing:

1. Location of study area, Superior-Hardy Special Protection Area, Nuckolls County, Nebraska......................... 4

2. Generalized geology of the study area, Nuckolls County, Nebraska.................................................................. 5

3. Altitude and configuration of the base of the aquifer system in the study area, Nuckolls County, Nebraska.

4. Altitude and configuration of the water table and direction of ground-water flow in the study area, Nuckolls County, Nebraska, fall 1992

5. Soil associations in the study area.

6. Agricultural land use in the study area, Nuckolls County, Nebraska, 1989

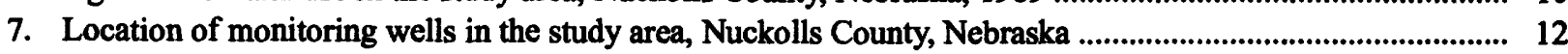

8. Boxplot of nitrate concentrations from year 1 baseline data prior to the implementation of the management plan and year 2 data after implementation of the plan in the study area, Nuckolls County, Nebraska ...................... 18

9. Map showing areal distribution of median nitrate concentrations in ground water from 16 fully penetrating wells in the study area, Nuckolls County, Nebraska, July 1991 through March 1992

10-15. Graphs showing:

10. Stratification of nitrate concentrations in water samples from wells 9 and 13 in the study area, Nuckolls County, Nebraska, 1991-93.

11. Difference in median nitrate concentrations between year 2 and year 1 in ground water from fully penetrating monitoring wells in the study area, Nuckolls County, Nebraska, 1991-93

12. Distribution of ammonium and nitrate concentrations and organic matter and silt-clay content with depth at site 1 of the study area, Nuckolls County, Nebraska, spring 1991-93. 
13. Distribution of ammonium and nitrate concentrations and organic matter and silt-clay content

with depth at site 9 of the study area, Nuckolls County, Nebraska, spring 1991-93

14. Nitrate content and total nitrogen and ammonium content beneath a corn field at site 1 in the study area, Nuckolls County, Nebraska, spring 1991-93

15. Nitrate content and nitrate and ammonium content beneath a corn field at site 9 in the study area, Nuckolls County, Nebraska, spring 1991-93

\section{TABLES}

1. Land use in the study area, Nuckolls County, Nebraska, 1989 .

2. Statistical summary of chemical quality of ground water in the study area, Nuckolls County, Nebraska, 1988..

3. Summary of monitoring-well characteristics in the study area, Nuckolls County, Nebraska, 1991

4. Nitrate concentrations in samples from monitoring wells in the study area, Nuckolls County, Nebraska, 1991-93

5. Summary of the sum of squares, the mean sum of squares, and its ranking for monthly nitrate concentrations in water samples from 16 wells in the study area, 1991-93

6. Mean organic-matter content, silt-clay content, and ammonium and nitrate concentrations as nitrogen in multiple sediment cores for site 1 in the study area, Nuckolls County, Nebraska, spring 1991-93.

7. Mean organic-matter content, silt-clay content, and ammonium and nitrate concentrations as nitrogen in multiple sediment cores for site 9 in the study area, Nuckolls County, Nebraska, spring 1991-93.

8. Summary of nitrate and ammonium contents in the unsaturated zone, sites 1 and 9 in the study area, Nuckolls County, Nebraska, spring 1991-93.

9. Concentrations of bromide in sediment cores and estimated content for site 1 in the study area, Nuckolls County, Nebraska, winter 1992 and spring 1993.

10. Concentrations of bromide in sediment cores and estimated content for site 9 in the study area, Nuckolls County, Nebraska, winter 1992 and spring 1993.

11. Water-quality data for samples from 20 monitoring wells in the study area, Nuckolls County, Nebraska, 1991-93.

12. Nitrate and ammonium concentrations as nitrogen in sediment cores for site 1 in the study area, Nuckolls County, Nebraska, spring 1991.

13. Nitrate and ammonium concentrations as nitrogen and organic-matter content in sediment cores for site 1 in the study area, Nuckolls County, Nebraska, spring 1992

14. Nitrate and ammonium concentrations as nitrogen and organic-matter content in sediment cores for site 1 in the study area, Nuckolls County, Nebraska, spring 1993

15. Estimation of nitrate and ammonium content in sediment for site 1 in the study area, Nuckolls County, Nebraska, spring 1991-93

16. Nitrate and ammonium concentrations as nitrogen in sediment cores for site 9 in the study area, Nuckolls County, Nebraska, spring 1991

17. Nitrate and ammonium concentrations as nitrogen and organic-matter content in sediment cores for site 9 in the study area, Nuckolls County, Nebraska, spring 1992

18. Nitrate and ammonium concentrations as nitrogen and organic-matter content in sediment cores for site 9 in the study area, Nuckolls County, Nebraska, spring 1993

19. Estimation of nitrate and ammonium content in sediment cores for site 9 in the study area, Nuckolls County, Nebraska, spring 1991-93.

20. Grain size and nitrate and ammonium concentrations as nitrogen in sediment cores for site 1 in the study area, Nuckolls County, Nebraska, spring 1991

21. Grain size and nitrate and ammonium concentrations as nitrogen in sediment cores for site 9 in the study area, Nuckolls County, Nebraska, spring 1991 


\section{CONVERSION FACTORS, VERTICAL DATUM, AND ABBREVIATIONS}

\begin{tabular}{rcl}
\hline Multiply & By & To obtaln \\
acre & 4,047 & square meter \\
foot $(\mathrm{ft})$ & 0.3048 & meter \\
foot per mile $(\mathrm{ft} / \mathrm{mi})$ & 0.1894 & meter per kilometer \\
gallon per minute $(\mathrm{gal} / \mathrm{min})$ & 0.00006309 & cubic meter per second \\
gallons per day per foot $[(\mathrm{gal} / \mathrm{d}) / \mathrm{ft})]$ & 0.0124 & square meter per day \\
inch per hour & 25.4 & millimeter per hour \\
inch per inch & 25.4 & millimeter per millimeter \\
mile & 1.609 & kilometer \\
pound $(\mathrm{lb})$ & 0.4536 & kilogram \\
pound per acre $(\mathrm{lb} / \mathrm{acre})$ & 1.120 & kilogram per hectare \\
square inch $\left(\mathrm{inch}^{2}\right)$ & 645 & square millimeter \\
square $\mathrm{mile}\left(\mathrm{mi}^{2}\right)$ & 2.590 & square kilometer \\
square foot per day $\left(\mathrm{ft}^{2} / \mathrm{d}\right)$ & 0.0929 & square meter per day \\
\hline
\end{tabular}

Temperature in degrees Fahrenheit $\left({ }^{\circ} \mathrm{F}\right)$ may be converted to degrees Celsius $\left({ }^{\circ} \mathrm{C}\right)$ as follows:

$$
{ }^{\circ} \mathrm{C}=\left({ }^{\circ} \mathrm{F}-32\right) / 1.8
$$

Sea level: In this report, "sea level" refers to the National Geodetic Vertical Datum of 1929 (NGVD of 1929) - a geodetic datum derived from a general adjustment of the first-order level nets of both the United States and Canada, formerly called Sea Level Datum of 1929.

\section{ADDITIONAL ABBREVIATIONS}

$\mathrm{mg} / \mathrm{L}$, milligrams per liter

$\mu \mathrm{g} / \mathrm{L}$, micrograms per liter

$\mathrm{mg} / \mathrm{kg}$, milligrams per kilogram 


\section{Distribution of Selected Nitrogen Compounds in Ground Water and the Unsaturated Zone, Superior-Hardy Special Protection Area, Nuckolls County, Nebraska, 1991-93}

By Abraham H. Chen

\begin{abstract}
A ground-water-quality monitoring network of 20 wells located at 16 sites was established in 1991 in the 32-square-mile Superior-Hardy Special Protection Area in Nebraska. The purpose of this network was to monitor long-term trends in concentrations of nitrate in ground water after a management plan was implemented in 1991. Nested monitoring wells were installed at two sites to examine vertical distribution of nitrate concentrations in the area.
\end{abstract}

Nitrate concentrations greater than 5 milligrams per liter were detected in 81 percent of the ground-water samples collected from the shallow aquifer during 1991-93. The occurrence of nitrate in ground water is related to groundwater flow direction and land-use patterns in the area. Nitrate concentrations ranged from 5 milligrams per liter in the northern part of the study area to 15 milligrams per liter in the southern part. Most of the large nitrate concentrations were found in areas of irrigated farmland, particularly in lowland areas.

Difference in nitrate concentration with depth was measured at two sites in the lowland area. Nitrate concentrations are largest at the top of the saturated zone and decline with depth; therefore, the fully penetrating, fully screened wells yield samples most representative of the entire saturated thickness of the aquifer.
Two sites were chosen for sediment coring during 3 consecutive years (1991-93) prior to fertilizer application in the spring to estimate the nitrate and ammonium, organic matter, and siltclay content of the unsaturated zone. Maximum concentrations of nitrate were detected at or within 13 feet of the land surface at both sites, suggesting that the major source of nitrogen at these sites is from the land surface. Bromide tracer experiments were conducted to estimate the annual rate of movement of nitrate in the unsaturated zone. Bromide tracer had leached to 9 and 13 feet below the land surface at the two sites. Thus, an annual rate of downward movement of nitrate was estimated to be about 11 feet. It may take about 2 years and more than 9 years for nitrate to reach ground water in the lowland and the upland, respectively.

Because of very slow ground-water movement and the time lag between the implementation of the management plan and water-quality improvement, significant changes in concentrations of nitrate in ground water were not detected during the study period ( 3 years). To identify changes in concentrations of nitrate in the ground water, long-term repetitive sampling over the spatial network is necessary. Such changes will be detected most quickly in the shallow ground water beneath the lowland area. 


\section{INTRODUCTION}

Continued detections of nitrate as nitrogen (nitrate) in the shallow aquifer in excess of the U.S. Environmental Protection Agency's (USEPA) Maximum Contamination Level (MCL) of 10 milligrams per liter (mg/L) (U.S. Environmental Protection Agency, 1994) in parts of the Lower Republican and Little Blue Natural Resources Districts (NRD) led to a request for a Special Protection Area (SPA) designation. After conducting a ground-water-quality investigation during the spring and summer of 1988, the Nebraska Department of Environmental Quality (NDEQ) concluded that nitrate concentrations in ground water were sufficiently widespread and large enough to justify establishment of Nebraska's first SPA in 1990. This designation required the Lower Republican and the Little Blue NRDs to create and implement a management plan in 1991 that would either improve or prevent more serious degradation of ground-water quality in the SPA. The management plan prepared for the SPA includes educational, regulatory, and long-term ground-water-quality monitoring elements. This plan was implemented within the SPA and includes practices such as crop fertilization, crop rotation, integrated pest management, irrigation, and livestockwaste, tillage, and buffer-zone management activities (Lower Republican and Little Blue Natural Resources Districts, 1990). The purpose of the ground-waterquality monitoring was to document changes in ground-water quality over time and to determine if the educational and regulatory elements will be effective in improving ground-water quality during the 10-year period of designation as an SPA.

In 1991, the U.S. Geological Survey (USGS) entered into a cooperative agreement with the NDEQ, the Lower Republican and Little Blue NRDs, and the Conservation and Survey Division, University of Nebraska-Lincoln (UNL), to:

1. Identify acceptable sites for monitoring-well locations and install a network of monitoring wells within the SPA;

2. Determine the variability of nitrate concentrations in ground water;

3. Examine possible timing of ground-water sample collection; and
4. Estimate the nitrate and ammonium content of the unsaturated zone at representative sites.

\section{Purpose and Scope}

This report identifies locations for monitoring wells and unsaturated-zone sampling sites and describes the results of monitoring for nitrate and ammonium during 1991-93. The report describes variations in concentrations of nitrate in ground water, describes nitrate and ammonium content of the unsaturated zone at two sites prior to fertilizer application, and describes possible timing of ground-water sample collection.

\section{Prevlous Investlgatlons}

Several geologic and hydrologic studies during the past 50 years have described the study area. Miller and others (1964) reported on the geography, geology, structural, historical, and economic geology of the study area. Bedrock geologic maps showing thickness of overlying Quaternary-age deposits were constructed by Burchett and others (1972) and Dreeszen and others (1973). Ground-water resources for Nuckolls County were described by Waite and others (1944). A hydrogeologic reconnaissance of the Republican River Basin was completed by Ellis (1981). A study of ground-water quality in southern Nuckolls County, which documented concentrations of nitrate and detections of atrazine, was completed by Ehrman (1989).

\section{Acknowledgments}

The assistance and cooperation of the following are greatly appreciated: personnel of the NDEQ for assistance with well logging; personnel of the Lower Republican and the Little Blue NRDs for assistance in well selection, logging and sampling; the drilling team of the Conservation and Survey Division, University of Nebraska-Lincoln; and numerous land owners and tenants who permitted access for the installation and sampling of monitoring wells. 
DESCRIPTION OF THE STUDY AREA

The Superior-Hardy SPA is located in southern Nuckolls County, south-central Nebraska, along the Kansas-Nebraska border (fig. 1). Superior, with a population of 2,397 in 1990 (U.S. Bureau of the Census, 1993), is located along the Republican River in the western part of the SPA. Hardy, with a population of 206 in 1990, is the only other population center within the study area. The SPA encompasses 32 square miles $\left(\mathrm{mi}^{2}\right)$, and is under jurisdiction of the Lower Republican and Little Blue NRDs.

The study area lies within the Plains Border Section of the Great Plains Physiographic Province (Fenneman, 1946). The area is characterized by moderate relief and dissected topography in the upland area, which gradually changes to a low relief in the lowlands of the Republican River Valley (fig. 1). The study area has an overall relief of about $160 \mathrm{ft}$, with the highest elevation in the northwest portion, and the lowest in the Republican River Valley at the KansasNebraska border. Major streams in the area are the Republican River and its tributaries, and Blakely and Crosby Creeks. Water is diverted from the Republican River upstream from the study area through the Superior Canal for surface-water irrigation in the Republican River Valley.

\section{Hydrogeology}

The geology of the Superior-Hardy SPA consists of Carlile Shale of Late Cretaceous age unconformably overlain by sand, silt, and clay deposits of Quaternary age (fig. 2). However, the Ogallala Formation of Tertiary age is absent in the study area. Carlile Shale is a mostly gray, clayey shale in the lower portion, capped by a fossiliferous, yellowbrown, sandy siltstone.

In the Republican River Valley, the Carlile Shale is unconformably overlain by deposits of Quaternary age. Alluvial deposits of Pleistocene age consist of alluvial material composed of unconsolidated silt, sand, and some gravel, some of which are nearly $50 \mathrm{ft}$ thick. Loess deposits of Pleistocene age overlie the alluvial deposits along the margins of the river valley and in the terrace and upland portions of the study area. The loess deposits are yellowish to grayish orange and may contain up to 10 percent sand and may exceed $100 \mathrm{ft}$ in thickness in the eastern portion of the study area. Terrace deposits, which consist of clayey to sandy silt of Holocene age, directly overlie the coarser alluvial deposits in the river valley and also the loess deposits along the margin of the river valley and in small stream channels cut into the loess. The shallow aquifer (part of the High Plains aquifer) is within alluvial and loess deposits of Quaternary age.

The altitude of the base of the shallow aquifer was assumed to be identical to the top of the Carlile Shale and was mapped using geologic information from 53 test holes, irrigation wells, and monitoringwell logs (fig. 3). The base of the aquifer system ranges in altitude from about $1,580 \mathrm{ft}$ above sea level in the northern part of the study area to about $1,480 \mathrm{ft}$ in the southern part. The slope is toward the south, and averages about 40 feet per $\mathrm{mile}(\mathrm{ft} / \mathrm{mi})$. The aquifer extends to the northern edge of the study area, where the altitude of the top of the Carlile Shale is similar to the altitude of the water table and the shallow aquifer is absent or very thin. As a result, the bedrock creates a boundary along the north side of the study area that isolates the study area from subsurface flow from the north.

The shallow aquifer in the study area is unconfined. The configuration of the water table (fig. 4) was produced from water-level measurements in 49 wells and 6 stream stage measurements during the fall of 1992 . The altitude of the water table ranges from $1,590 \mathrm{ft}$ above sea level in the northern part of the study area to $1,520 \mathrm{ft}$ above sea level in the southern part of the study area, indicating a general north-to-south direction of ground-water flow and an average hydraulic gradient of about $30 \mathrm{ft} / \mathrm{mi}$. Ground water generally discharges into the Republican River in the southern part of the study area. However, municipal ground-water withdrawals in the northwestern part of the study area have caused local depressions in the water table.

Based on well data from the 54 wells, depth to water ranged from near zero in the Republican River Valley and two perennial stream valleys, Blakely Creek in the western part and Crosby Creek in the central part of the study area, to about $160 \mathrm{ft}$ in upland areas in the eastern part of the study area. Depths to water in upland areas generally were about $130 \mathrm{ft}$ in the eastern part of the upland area, $48 \mathrm{ft}$ in remaining upland areas, and $16 \mathrm{ft}$ in the lowland.

Saturated thickness was measured by subtracting the elevation of the base of the aquifer from the elevation of the fall 1992 water-table surface. 


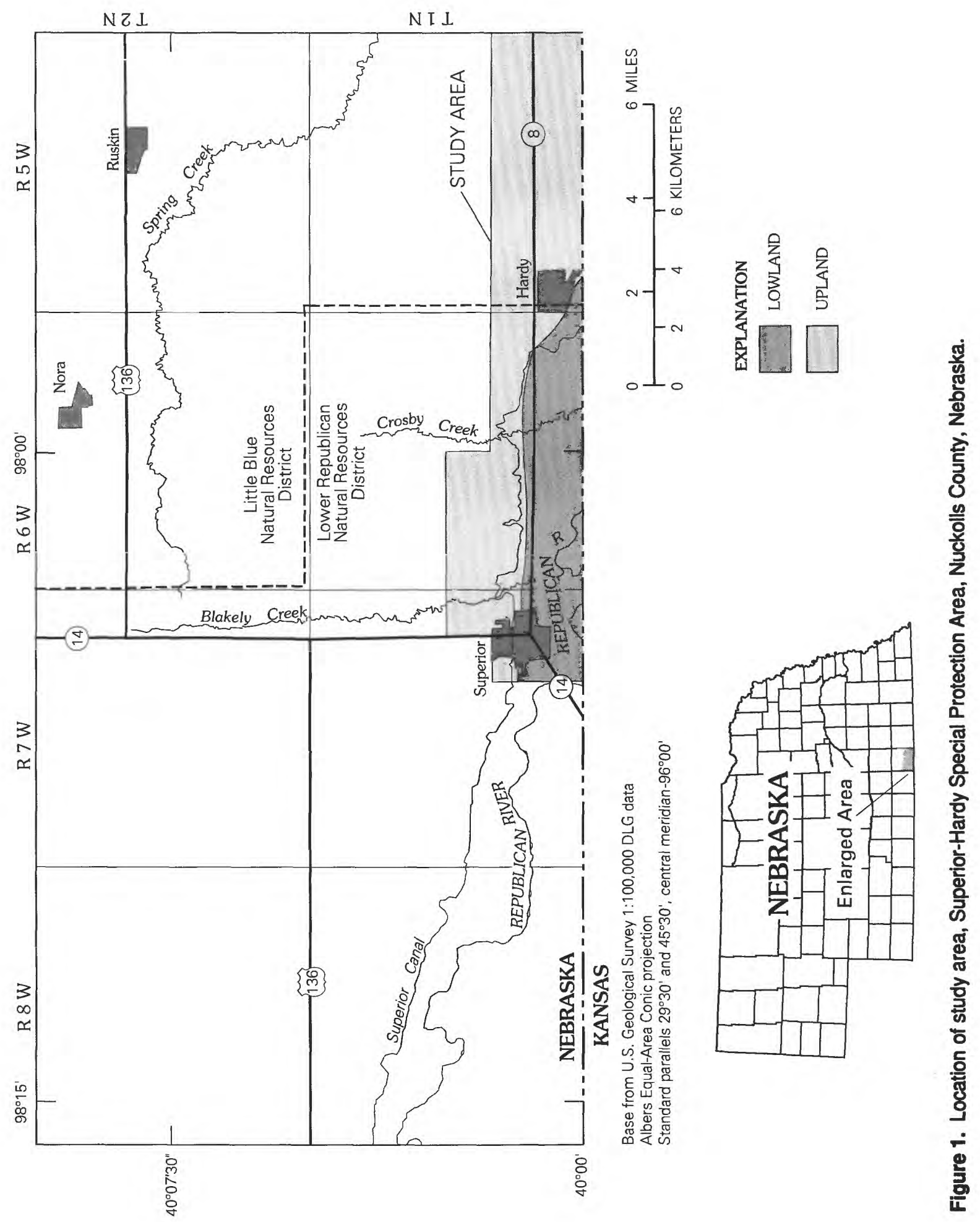



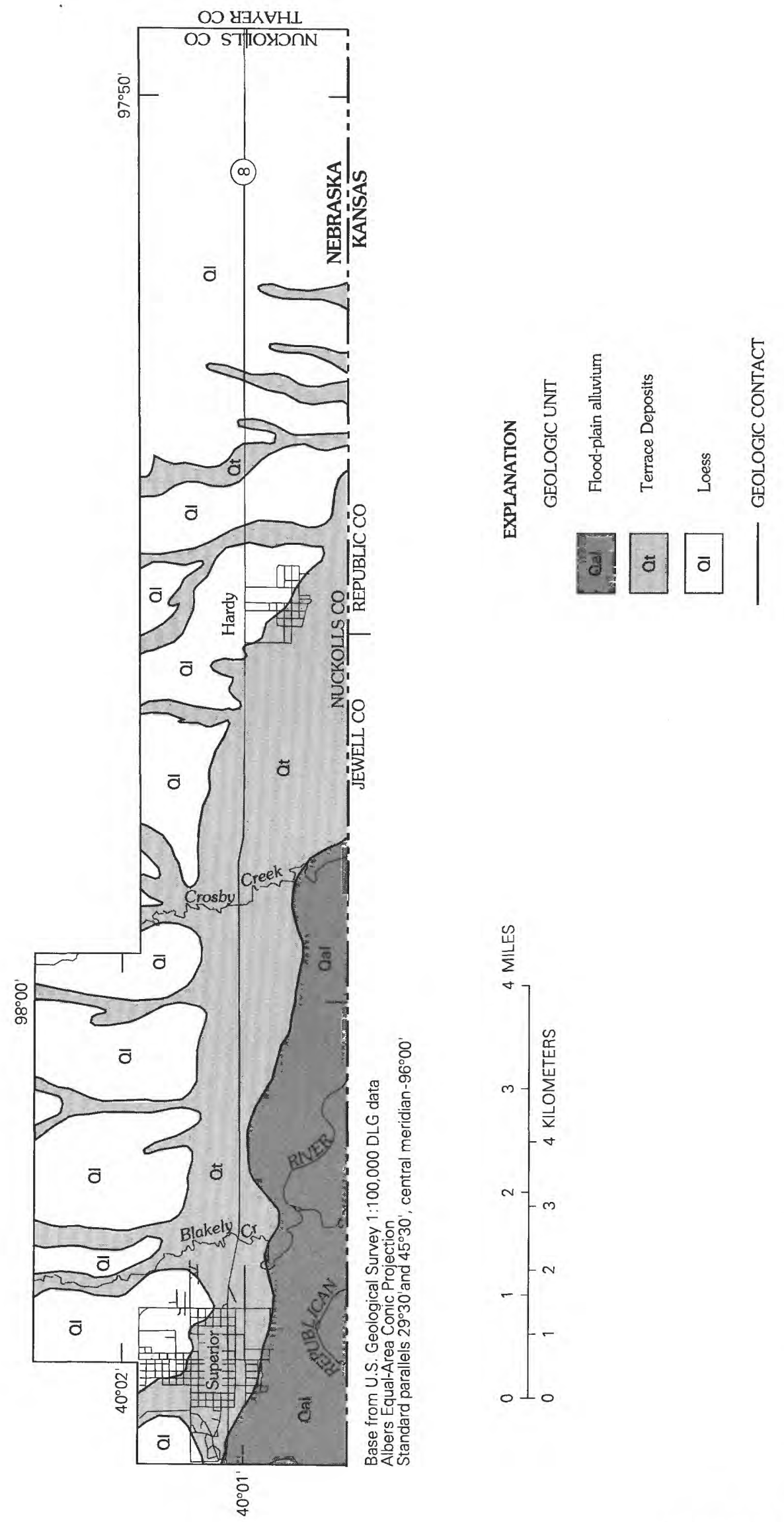

\%

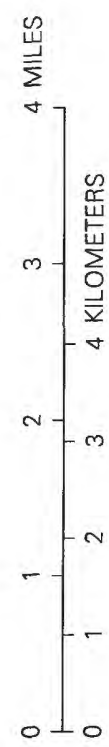

흥

흠

बัฒ

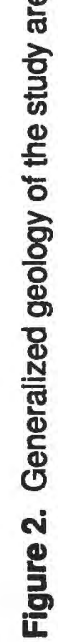



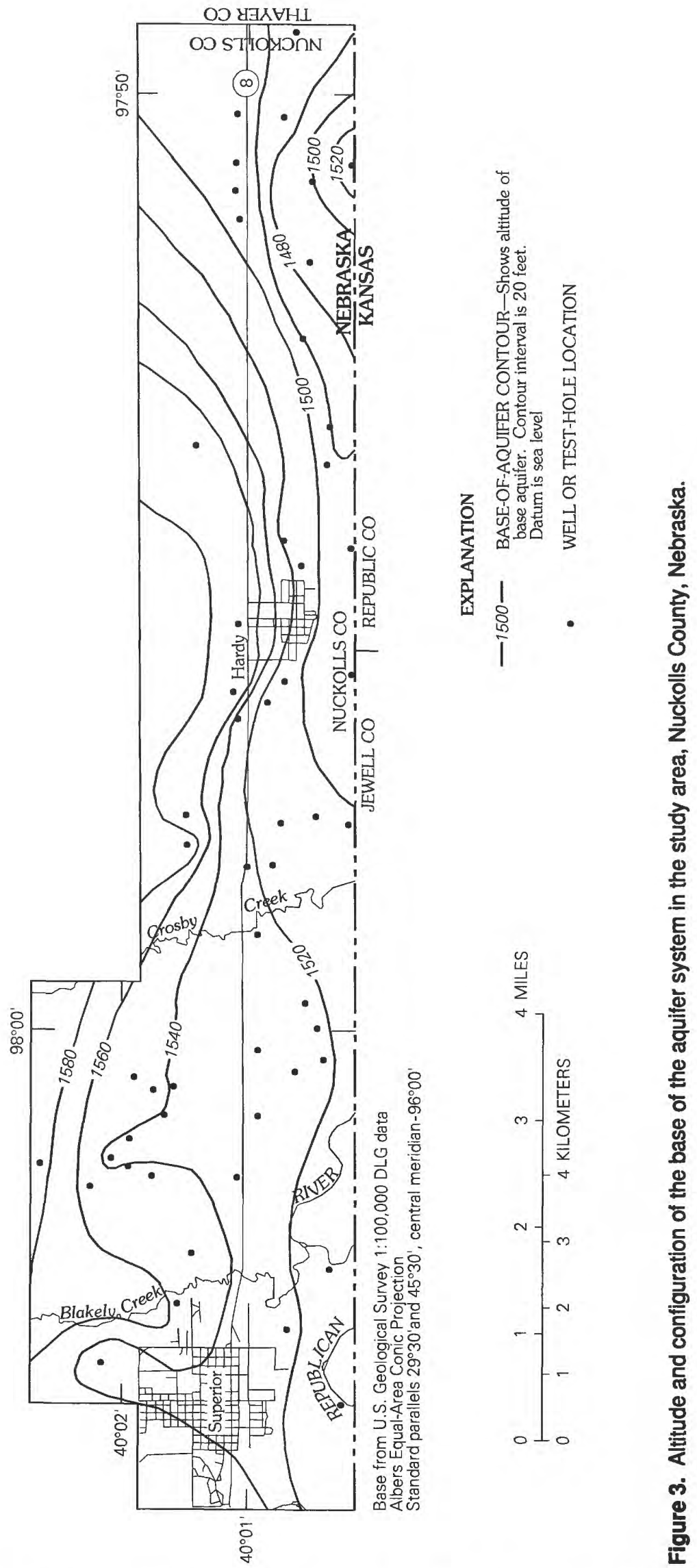

6 Distribution of Selected Nitrogen Compounds in Ground Water and the Unsaturated Zone, Superior-Hardy Special Protectlon Area, Nuckolls County, Nebraska, 1991-93 

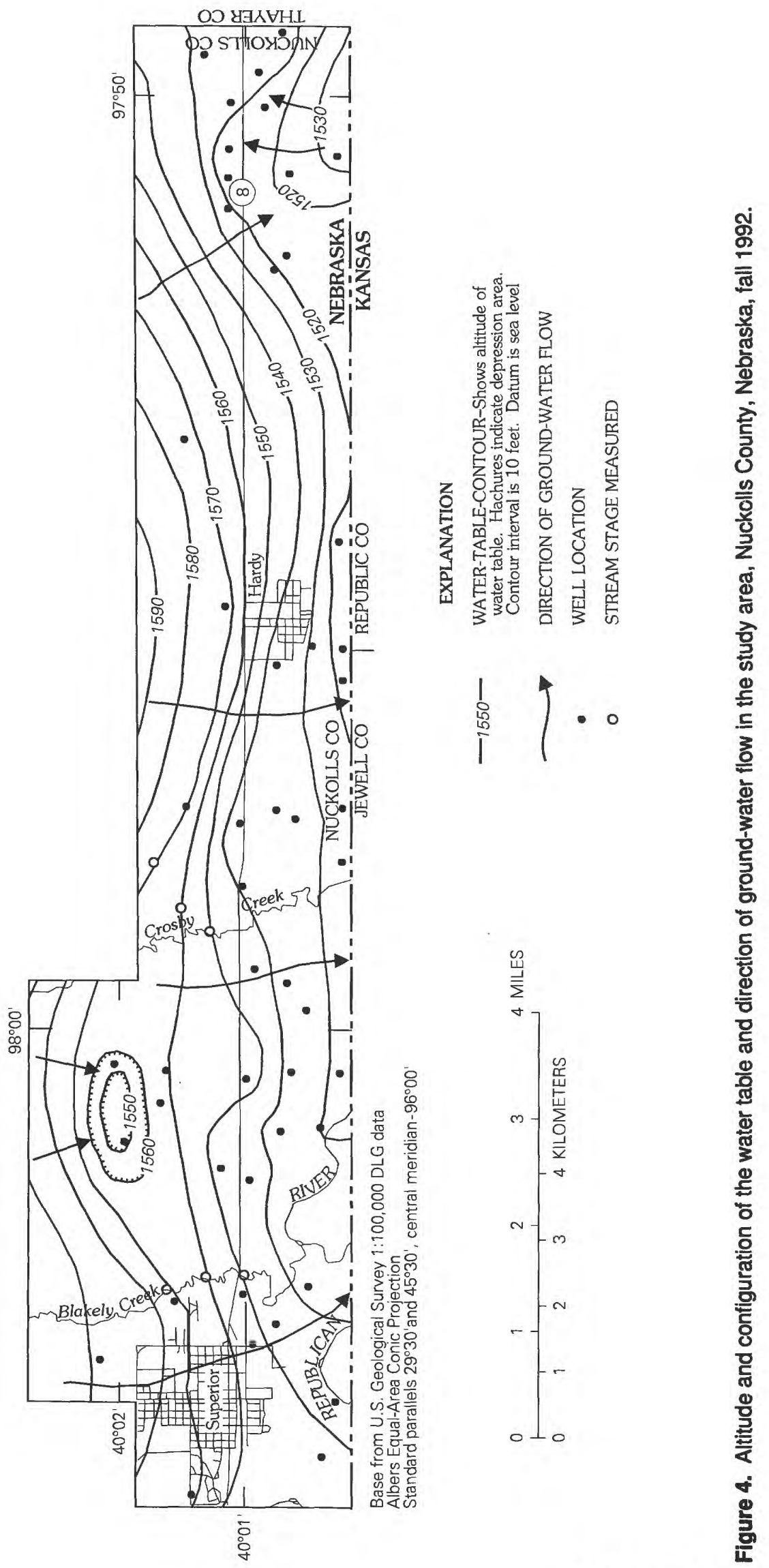
Saturated thickness at well locations ranged from 3 to $33 \mathrm{ft}$, with a mean of $16 \mathrm{ft}$ in the lowland areas, and from 2 to $55 \mathrm{ft}$, with a mean of $24 \mathrm{ft}$, in upland areas.

Transmissivity $(T)$ is a measure of the ability of the aquifer to transmit water, and is largely dependent on the nature of the pore space and thickness of the aquifer. T values in the Republican River Valley near Superior and on the terraces east of Hardy range from about 3,000 to more than 13,000 square feet per day $\left(\mathrm{ft}^{2} / \mathrm{d}\right)$ (Lower Republican Natural Resources District, 1990). In the upland area, $T$ values range from zero to about $3,000 \mathrm{ft}^{2} / \mathrm{d}$. T values in the extreme eastern part of the study area, where some saturated sand and gravel are present, exceed 13,000 $\mathrm{ft}^{2} / \mathrm{d}$ (Lower Republican and Little Blue Natural Resources Districts, 1990).

\section{Soils}

Major soil associations within the study area are shown in figure 5. The Crete-Hastings Soil Association (fig. 5) is located in the extreme northeastern portion of the study area and is formed in loess on nearly level to gently sloping upland. The association consists of silt loam to silty-clay loam soils that have permeabilities less than 1.0 inch per hour and a waterholding capacity of about 0.19 inch per inch (Dugan, 1984). It contains soils with a moderate to high shrink-swell potential. Large cracks are commonly found during dry periods and offer potential routes for the rapid movement of water into the subsurface.

The Geary-Hastings Soil Association also is formed in loess and is located in the northern and eastern parts of the study area (fig. 5). Hydrologic properties of this association are similar to soils of the Crete-Hastings Soil Association. Slopes are nearly level to moderately steep with an average maximum soil slope of 14 percent.

The Hord Soil Association (fig. 5) contains silty-clay loams to silt loams with permeabilities from 1 to 2 inch per hour. These soils are present on the stream terraces north of the Republican River and have a moderate to low shrink-swell potential. The water-holding capacity of these soils is about 0.20 inch per inch.

The McCook-Wann-Inavale Soil Association is located along the Republican River in the study area (fig. 5). The association consists of silt-loam to loamy sands with high permeabilities of 5 to 10 inches per hour. The water-holding capacity of these soils is about 0.12 inch per inch.

\section{Land Use}

The principal land use in the study area is agricultural, with about 89 percent of all land used for crop or livestock production (fig. 6, table 1). This land use consists primarily of irrigated ( 29 percent) and nonirrigated ( 38 percent) cropland, and rangeland (22 percent). A summary of land use in the area during 1989 is presented in table 1.

Crops raised in the area include corn, sorghum, soybeans, wheat, oats, alfalfa, and hay. The irrigated cropland is dominated by corn and soybeans, whereas the nonirrigated cropland is dominated by corn, sorghum, and small grains. Pasture and rangeland are utilized mainly for cattle production.

Within lowlands of the study area, 3,690 acres of cropland (or 63 percent of irrigated land) were irrigated by surface water diverted from the Republican River through the Superior Canal. Remaining irrigation was by sprinkler systems using ground water.

Current corn-production techniques often require significant quantities of nitrogen fertilizers, pesticides, and irrigation water to achieve optimum yields. Farmers commonly apply from 80 to $250 \mathrm{lb}$ of total nitrogen per acre annually, mostly as anhydrous ammonia, to supplement available nitrogen in the soil (University of Nebraska, 1989).

\section{Ground-Water Quality}

Ground water in the study area is of the calcium bicarbonate type (Engberg, 1984) and contains moderate amounts of sulfate, sodium, chloride, nitrate, and other constituents. Results from 10 ground-waterquality samples retrieved from the USGS Water Data Storage and Retrieval System (WATSTORE), collected prior to irrigation (pre-1950) in the lowland, indicated that nitrate concentrations in ground water were less than $1 \mathrm{mg} / \mathrm{L}$. Thirty-seven water-quality samples were collected within the study area during the spring and summer of 1988 (Ehrman, 1989). Two water samples were considered to be affected by point-source contaminants and were eliminated from 

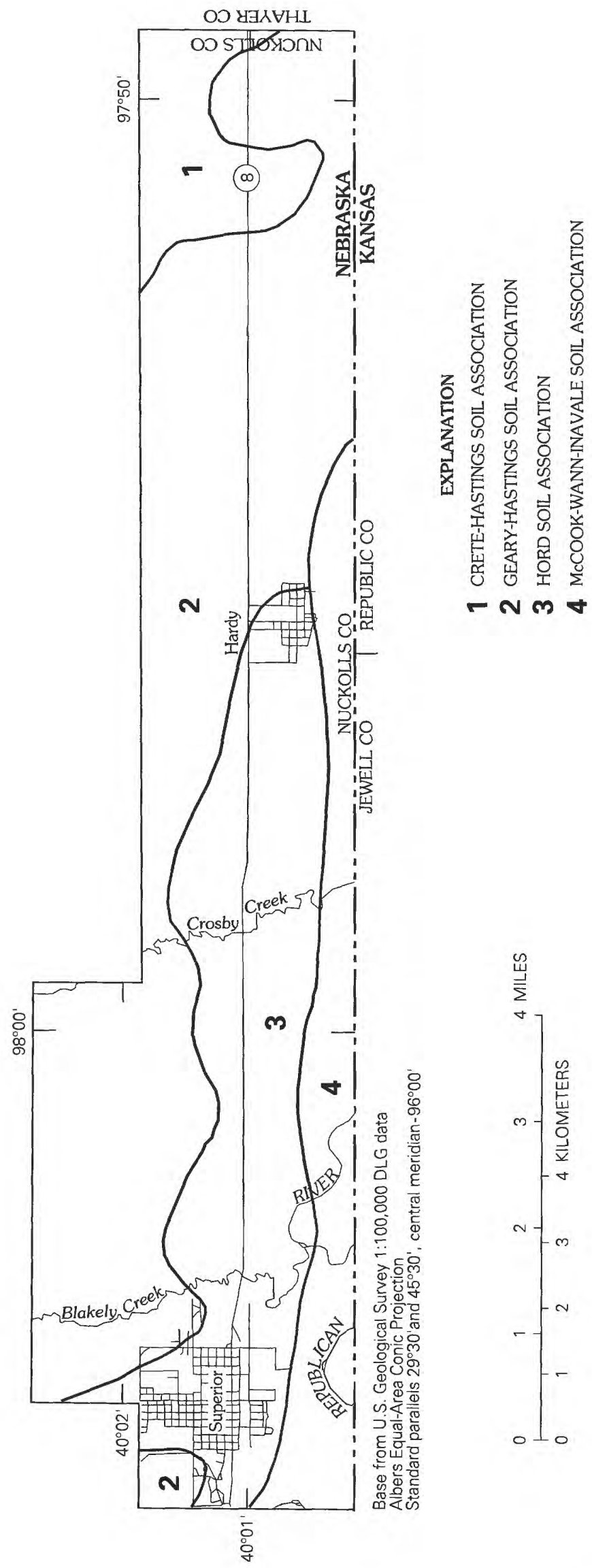

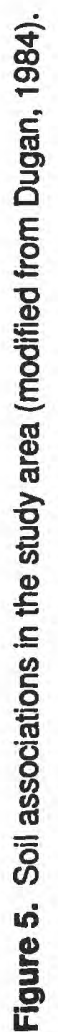



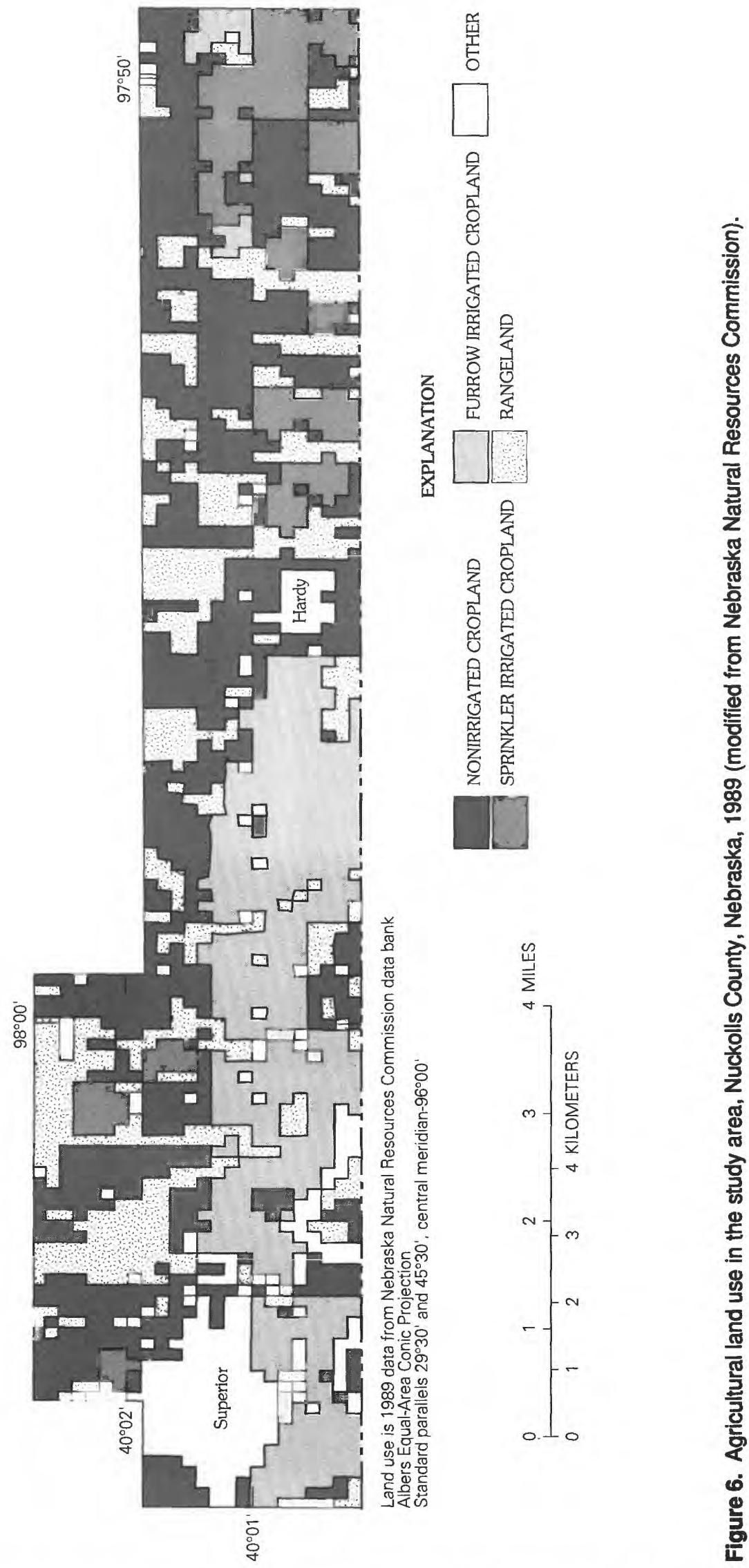
the data set. A statistical summary of these waterquality data is presented in table 2 .

Table 1. Land use in the study area, Nuckolls County, Nebraska, 1989

[Data from Nebraska Natural Resources Commission]

\begin{tabular}{lcc}
\hline \multicolumn{1}{c}{ Land use } & Acreage & Percentage \\
\hline Irrigated cropland & 5,845 & 28.5 \\
\multicolumn{1}{c}{ Sprinkler irrigated } & 1,418 & 6.9 \\
Furrow irrigated & 4,427 & 21.6 \\
Nonirrigated cropland & 7,844 & 38.3 \\
Rangeland & 4,571 & 22.3 \\
Forest land & 450 & 2.2 \\
Other farmland & 400 & 2.0 \\
Built-up land & 1,280 & 6.3 \\
Water & 90 & 0.4 \\
Total & 20,480 & 100 \\
\hline
\end{tabular}

Data from Ehrman (1989) indicate that most concentrations of the dissolved constituents analyzed were within recommended limits for public drinkingwater supplies (U.S. Environmental Protection Agency, 1994). However, concentrations of nitrate in 12 out of 35 samples ( 34 percent) exceeded the USEPA's MCL of $10 \mathrm{mg} / \mathrm{L}$ for nitrate. Nitrate as nitrogen concentrations ranged from about 3 to $17 \mathrm{mg} / \mathrm{L}$, with a mean of $8.3 \mathrm{mg} / \mathrm{L}$ (table 2 ).

The areal distribution of nitrate in ground water (Ehrman, 1989) indicates that nitrate concentrations were highest in the central and eastern parts of the study area. The distribution of higher nitrate values correlates with the location of irrigated cropland in the study area (Ehrman, 1989). Pesticides such as atrazine were detected in seven of eight samples, ranging from 2.4 to 4 micrograms per liter $(\mu \mathrm{g} / \mathrm{L})$. Three samples collected by Ehrman (1989) exceeded the USEPA proposed MCL for atrazine of $3 \mu \mathrm{g} / \mathrm{L}$ (U.S. Environmental Protection Agency, 1994).

\section{METHODS}

\section{Site Selectlon and Monitoring-Well Installation}

Sixteen monitoring sites were selected

(fig. 7). Criteria used in determination of the number and locations of monitoring wells included geologic setting, saturated thickness, depth to water, groundwater flow direction, soil characteristics, land use, water-quality data, accessibility, and cost. The 16 sites were subdivided into three groups according to landuse intensity. Monitoring sites 4, 6, 8, 12, and 14 were located within nonirrigated upland (cropland and rangeland); sites $1,2,3$, and 5 were located in irrigated upland, closely situated downgradient from irrigated cropland; and sites $7,9,10,11,13,15$, and 16 were located within surface-water furrow-irrigated cropland, on the lowland.

Table 2. Statistical summary of chemical quality of ground water in the study area, Nuckolls County, Nebraska, 1988

[Data from Ehrman, $1989 ;{ }^{\circ} \mathrm{C}$, degrees Celsius; $\mu \mathrm{S} / \mathrm{cm}$, microsiemens per centimeter at $25^{\circ} \mathrm{C}$; $\mathrm{mg} / \mathrm{L}$, milligrams per liter]

\begin{tabular}{|c|c|c|c|c|c|c|c|}
\hline $\begin{array}{c}\text { Properties, constituents, } \\
\text { and units }\end{array}$ & $\begin{array}{c}\text { Number } \\
\text { of } \\
\text { analyses }\end{array}$ & Minimum & $\begin{array}{c}\text { 25th } \\
\text { percentile }\end{array}$ & $\begin{array}{c}\text { 50th } \\
\text { percentile }\end{array}$ & Mean & $\begin{array}{c}\text { 75th } \\
\text { percentile }\end{array}$ & Maximum \\
\hline Temperature, ${ }^{\circ} \mathrm{C}$ & 35 & $\overline{12}$ & 13 & 14 & 14 & $\overline{14}$ & $\overline{15}$ \\
\hline pH, standard units & 35 & 6.7 & 6.9 & 7.0 & 7.2 & 7.1 & 8.1 \\
\hline Specific conductance, $\mu \mathrm{S} / \mathrm{cm}$ & 35 & 111 & 587 & 639 & 665 & 768 & 997 \\
\hline Calcium, dissolved, $\mathrm{mg} / \mathrm{L}$ & 35 & 65 & 81 & 93 & 94 & 104 & 136 \\
\hline Magnesium, dissolved, $\mathrm{mg} / \mathrm{L}$ & 35 & 8.6 & 10 & 13 & 13 & 15 & 20 \\
\hline Sodium, dissolved, $\mathrm{mg} / \mathrm{L}$ & 35 & 10 & 35 & 45 & 47 & 58 & 80 \\
\hline Chloride, dissolved, $\mathrm{mg} / \mathrm{L}$ & 35 & 5.6 & 21 & 34 & 36 & 41 & 134 \\
\hline Sulfate, dissolved, $\mathrm{mg} / \mathrm{L}$ & 35 & 17 & 26 & 47 & 49 & 64 & 96 \\
\hline Potassium, dissolved, $\mathrm{mg} / \mathrm{L}$ & 35 & 3.8 & 4.8 & 5.3 & 5.9 & 6.6 & 12 \\
\hline Nitrate as nitrogen, $\mathrm{mg} / \mathrm{L}$ & 35 & 2.9 & 4.8 & 8.3 & 8.3 & 10 & 17 \\
\hline
\end{tabular}




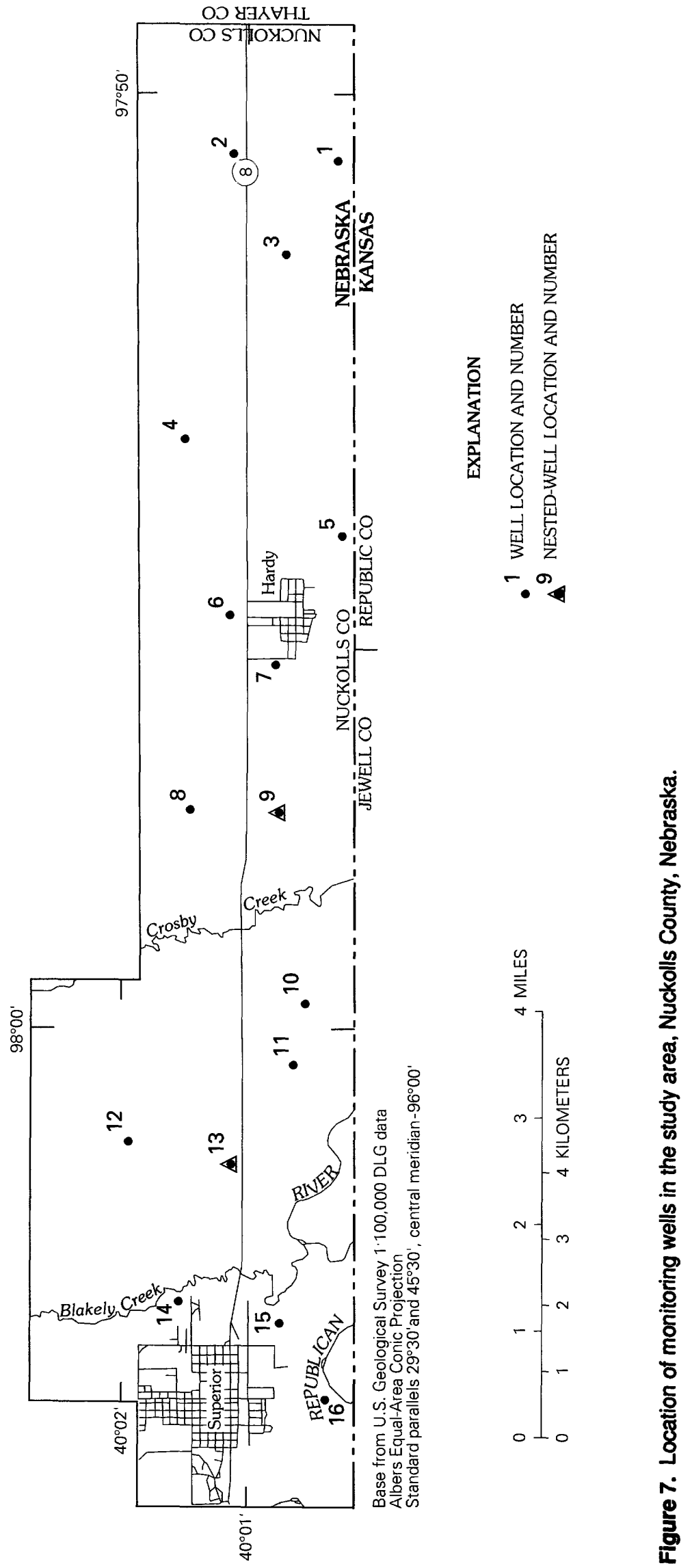

12 Distribution of Selected Nitrogen Compounds in Ground Water and the Unsaturated Zone, Superlor-Hardy Special Protection Area, Nuckolls County, Nebraska, 1991-93 
Twenty monitoring wells were installed at the 16 sites in May 1991 to monitor overall regional water quality. In this report, each monitoring well is identified by the same number as the corresponding numbered site. Nests of three wells were installed at sites 9 and 13 with various screened depths $(A, B$, and C) to monitor vertical distribution of nitrate in the area. Well A was screened throughout most of the aquifer; well B was screened at the bottom $2 \mathrm{ft}$ of the aquifer; and well $\mathrm{C}$ was screened at the top $5 \mathrm{ft}$ of the aquifer. Extensions of casing below the screens of three wells $(4,9 \mathrm{C}$, and $13 \mathrm{C})$ were designed to facilitate sampling of ground water during low water-table conditions.

A reverse-circulation, rotary drilling method was used in drilling the wells to eliminate possible contamination of ground-water samples with drilling fluids and to minimize reduced permeability from injection of drilling fluids into the aquifer. All wells were completed with full penetration of the aquifer, except wells 9B, 9C, 13B, and 13C.

Four-inch outside diameter, schedule 40, flushthreaded polyvinyl chloride casing and screen were installed in all monitoring wells. Continuous-slot screen with 0.012 -inch slots, providing 8.160 square inches of open area per linear foot, permitted effective well development without plugging and facilitated rapid recharge to the well. Table 3 summarizes the characteristics of the 20 monitoring wells.

Gravel from a local source was used to backfill around the screened intervals to a height of 2 to $3 \mathrm{ft}$ above the top of the screen. The remainder of the annular space was filled to $3 \mathrm{ft}$ below the land surface with bentonite slurry that was pumped in with a tremie pipe. The uppermost part of the 3-ft annular space was filled with a cement seal to prevent downward seepage along the well casing. Steel well protectors with locking caps were cemented in place around the tops of the well casing. The wells were developed by surge pumping with a suction-lift centrifugal pump until the water was free from suspended particulate.

\section{Water-Quality Sampling and Analysis}

During June 1991, pumps for monitoring wells were installed and samples were collected once during the months of July, September, and November, and twice during August at each well. A bimonthly (January, March, May, July, September, and November) sampling schedule was established in January 1992. A stainless-steel, submersible pump was installed permanently in all wells except 1,6 , and 8 , which avoided the potential problem of cross contamination between wells during sampling and reduced labor costs. A bailer was used to sample wells 1,6 , and 8 , where the aquifer is thin and/or composed of sediment with low permeability. Samples were sent to the National Water Quality Laboratory (NWQL) in Arvada, Colorado, for analysis of dissolved nitrate as nitrogen. Nitrogen ${ }^{15} \mathrm{~N}$ stable isotope analysis was also done by the NWQL's contract laboratory.

Water samples were collected after 3 to 10 casing volumes had been purged to ensure that stagnant water was removed from the well prior to sample collection. A flow-through chamber fitted with field instrument probes was used to monitor $\mathrm{pH}$, specific conductance, dissolved oxygen, and temperature of the water during well purging. A sample was collected only after the field measurements stabilized. General sample collection, treatment, preservation, and storage and shipping procedures conformed to those described by Kolpin and Burkart (1991).

Quality assurance and quality control of the analytical data were maintained through an integration of procedures at the NWQL, field-sampling protocols, and data reviews by the USGS. All bottles and preservatives used for water samples were subjected to quality-control measures at the NWQL to decrease the chance of sample contamination. A minimum of 15 percent of all analyses performed for any given constituent at the NWQL consists of reference materials from the USEPA and the National Bureau of Standards, spiked samples, blanks, and samples split between different laboratories as recommended by Fishman and Friedman (1989).

Ten percent of the samples collected for nitrate analysis were duplicate quality-assurance samples. The duplicate samples were collected in separate containers immediately following collection of the regular sample and sent to the NWQL for analysis. Precision, which is the measure of the variability of individual sample measurements, was assessed from analyses of duplicate samples and expressed as standard deviation for the concentration data.

Analytical results were compared with previous results for each site and with other study sites to identify possible inconsistencies. If inconsistencies were identified, checks for transcribing errors were performed at the NWQL, and analytical reruns were requested as appropriate. 


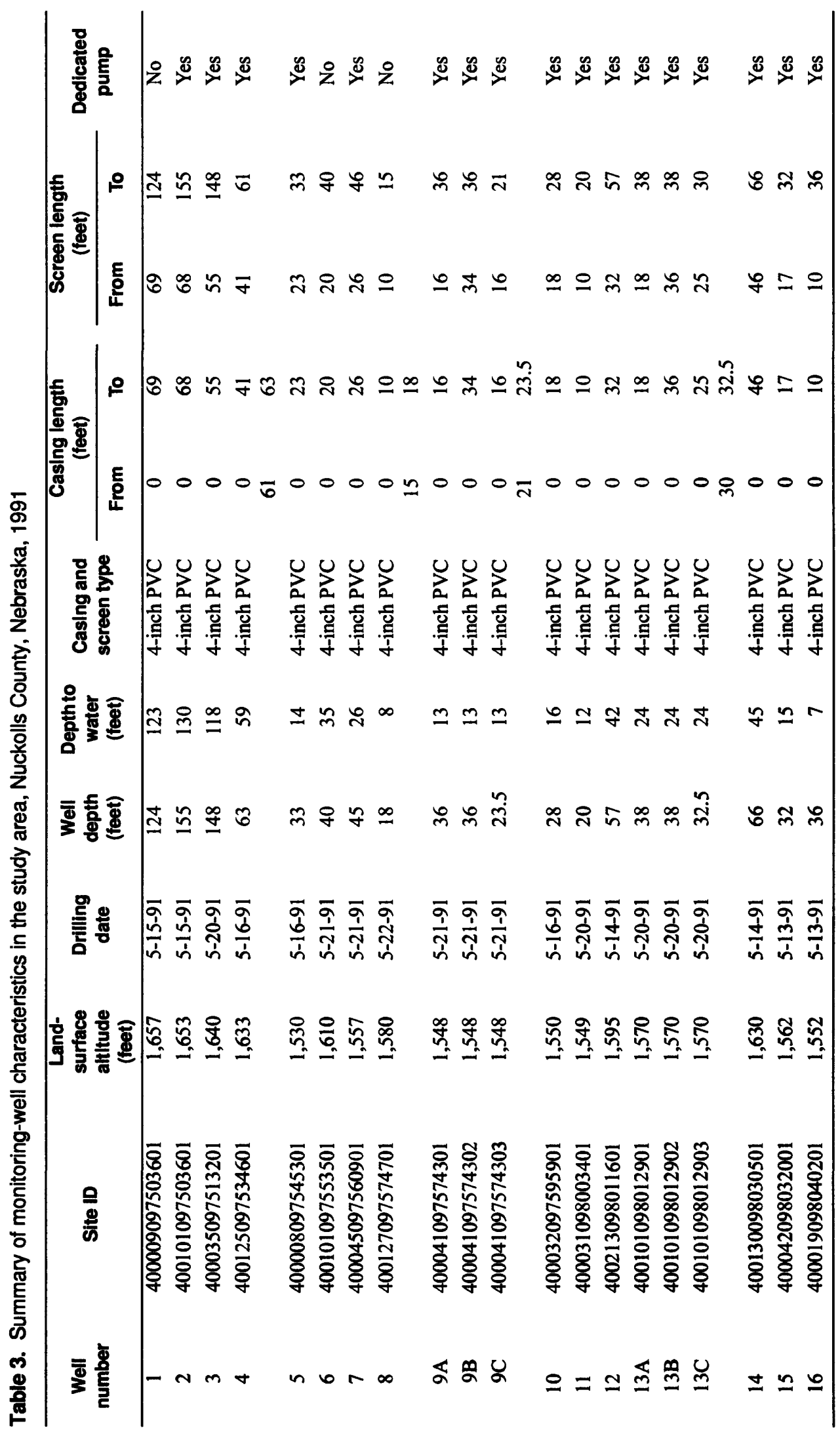

14 Distribution of Selected Nitrogen Compounds in Ground Water and the Unsaturated Zone, Superlor-Hardy Special Protection Area, Nuckolls County, Nebraska, 1991-93 


\section{Unsaturated-Zone Sampling and Analysis}

Sediment cores were collected and analyzed to provide estimates of the amounts and vertical distribution of residual nitrogen in the unsaturated zone at two sites in the study area. These results provided the basis for estimating the amount of nitrogen potentially available for eventual leaching into the ground water. Measurements of a conservative tracer through the soil and sediment profiles provided an estimate of the potential rate of nitrogen transport within the unsaturated zone.

Two sites, located in corn fields representative of surface-irrigated lowland (site 9) and sprinklerirrigated upland (site 1), were selected for sediment coring and nitrogen analysis. Both sites had been in continuous corn production, had 150 to $200 \mathrm{lb}$ of nitrogen per acre applied annually, and utilized minimum tillage practices prior to 1991 . In this report, site numbers used in reference to sediment coring-site locations correspond to numbers used to identify well-site locations.

Sediment cores of the unsaturated zone were collected annually from 1991 to 1993, prior to fertilizer application in the spring with a hollow-stem auger drilling rig operated by the Conservation and Survey Division, UNL. The sediment cores at sites 1 and 9 were collected at locations approximately $200 \mathrm{ft}$ from wells 1 and 9, respectively, on April 3, 1991, February 4, 1992, and April 27, 1993. Replicate cores also were collected at the sediment- coring sites each year- two holes at each site in 1991 and three holes at each site in 1992 and 1993. Approximately 3-inch portions of core samples were collected every $3 \mathrm{ft}$, or at each major lithological change, in each hole through depths of about 73 and $20 \mathrm{ft}$ for sites 1 and 9, respectively. Core samples were analyzed by the Geology Department, UNL, for grain size, and by the Soil Testing Laboratory, Department of Agronomy, UNL, to determine organic matter content, nitrate- $\mathrm{N}$, and ammonium- $\mathrm{N}$ concentrations.

To determine the approximate rate at which nitrate may be transported through the unsaturated zone, two tracer experimental plots, $30 \times 30 \mathrm{ft}$, were located in corn fields at well sites 1 and 9 (fig. 7). Both plots were flat with a 0 - to 1-percent slope. Bromide (as potassium bromide), a conservative tracer whose transport behavior is similar to nitrate, was applied at a rate of $267.6 \mathrm{lb} /$ acre to each of the plots on May 19, 1992. Bromide was not detected in core samples of the unsaturated zone prior to fertilizer and bromide application in February 1992.

Bromide analyses of core samples collected in February 1992 and April 1993 for the tracer experiments were conducted by the UNL Soil Testing Laboratory. Bromide was extracted from sediment cores using potassium chloride and analyzed using a cadmium-reduction method. An ion chromatograph using an ion-exchange resin in combination with a specific effluent was used to analyze for bromide.

Concentrations of nitrate- $\mathrm{N}$, ammonium- $\mathrm{N}$, and bromide were converted to pounds per acre using the following formula (Follett and others, 1991):

$$
\begin{gathered}
\mathrm{NO}_{3}-\mathrm{N}(\mathrm{lb} / \mathrm{acre})= \\
\mathrm{NO}_{3}(\mathrm{mg} / \mathrm{L}) \times 0.3 \times \text { interval thickness (inches) }
\end{gathered}
$$

(corresponding calculations can be done for ammonium and bromide), where 0.3 is a unit conversion factor, and the interval thickness is bounded by the midpoints between core sample depths in the core above and below the recorded sample depth.

\section{Statistical Data Analysis}

Descriptive statistical analysis, boxplots, and nonparametric statistical tests were used to summarize and evaluate data collected during 1991-93. Descriptive statistics such as the mean, median, maximum, minimum, standard deviation, and percentile aided in the interpretation of data. Percentiles show the percentage of analyses equal to or less than the indicated value. Boxplots present the median and the 10 th, 25 th, 75 th, and 90 th percentiles in graphical form.

The Mann-Whitney and Wilcoxon tests (Conover, 1989), nonparametric hypothesis tests involving rank-transformed data, were used when comparing two independent groups of data. Hypothesis tests are done to examine to what extent differences in data may be due to chance variability. The hypothesis tests involve a null hypothesis, which states that no real difference exists. The alpha value, or level or significance, that is used in hypothesis testing in this report is 0.05 . This value represents the maximum probability of rejecting the null hypothesis when it actually is true. For each test, the probability (given as a p-value) representing the attained significance level also is presented. If the p-value is smaller than or equal to the alpha value, the null hypothesis is 
rejected and the tested data groups are considered to be significantly different.

\section{DISTRIBUTION OF SELECTED NITROGEN COMPOUNDS}

The following analysis is based on the data collected from 20 wells and from two selected unsaturated-zone sampling sites during 1991-93. Precision of data for water-quality analysis was expressed as a standard deviation of $0.3 \mathrm{mg} / \mathrm{L}$. This indicates that multiple analysis of duplicate samples coincides.

\section{Nitrate in Ground Water}

Results of detailed chemical and physical analyses of ground-water samples collected during this study are listed in table 11 at the back of the report. Concentrations of nitrate in ground water collected during this study are statistically summarized in table 4. Average yearly nitrate concentrations were computed by averaging all samples collected during a growing season (April to September) and a nongrowing season (October to March).

Nitrate data collected during the growing and nongrowing seasons of 1991-92, were reported as year 1 data. Because these data were obtained just prior to implementation of the management plan, they are regarded as baseline data. These data provide a basis for comparison of nitrate concentrations in the study area over time. Baseline nitrate year 1 data (July 1991-March 1992) and year 2 nitrate data (April 1992-March 1993) are illustrated in figure 8.

Results indicate that ground-water samples from all fully penetrating monitoring wells in the aquifer contained detectable concentrations of nitrate, and that samples from 12 of 16 ( 75 percent) wells contained median concentrations greater than $5 \mathrm{mg} / \mathrm{L}$. Samples from 7 of 16 ( 44 percent) wells contained median concentrations that exceeded $10 \mathrm{mg} / \mathrm{L}$. Median nitrate concentrations of $5 \mathrm{mg} / \mathrm{L}$ or more also were found in ground-water samples from three upland sites (wells 1, 2, and 3) at depths as much as $100 \mathrm{ft}$ or more below the land surface.

Baseline data (year 1) (table 4) indicate that nitrate concentrations in ground water for the entire study area ranged from 0.08 to $30 \mathrm{mg} / \mathrm{L}$, with a median of $8.7 \mathrm{mg} / \mathrm{L}$. Nitrate concentrations for the same period in nonirrigated uplands ranged from 1.9 to $25 \mathrm{mg} / \mathrm{L}$, and had the smallest median value of $5.2 \mathrm{mg} / \mathrm{L}$. Within irrigated land, median concentrations of nitrate for upland and lowland areas were 9.0 and $9.5 \mathrm{mg} / \mathrm{L}$, respectively, whereas the extremes ranged from 5.0 to $15.0 \mathrm{mg} / \mathrm{L}$, and from 0.08 to $30 \mathrm{mg} / \mathrm{L}$, respectively.

\section{Areal Distribution}

Figure 9 indicates that the distribution of nitrate concentrations in ground water relates to ground-water flow direction (fig. 4) and land use (fig. 6). Median nitrate concentrations ranged from $5 \mathrm{mg} / \mathrm{L}$ in the northern part of the study area, where nonirrigated land use is dominant, to $15 \mathrm{mg} / \mathrm{L}$ in the Republican River Valley, where irrigated corn is the dominant land use. Most monitoring wells in which greater nitrate concentrations were detected were located within or near the areas of irrigated corn, which is generally associated with high-nitrogen fertilizer and water applications.

Relatively large concentrations of nitrate were present in water samples in year 1 from wells 4 and 15 , with median concentrations of $24 \mathrm{mg} / \mathrm{L}$ (table 4 ). Isolated large nitrate concentrations are a possible indication of a point source. Therefore, additional samples were collected and analyzed for isotopic nitrogen to help identify potential nitrate sources. Nitrate derived from human and animal wastes typically has a nitrogen isotopic ratio $\left(\delta^{15} \mathrm{~N}\right)$ in the range of 10 to 22 parts per thousand (\%); nitrate derived from natural organic material in soil has $\delta^{15} \mathrm{~N}$ from 4 to $9 \%$ (Aravena and others, 1993); and nitrate derived from commercial fertilizers has $\delta^{15} \mathrm{~N}$ from -4 to $4 \%$ (Gormly and Spalding, 1979; Komor and Anderson, 1993). The $\delta^{15} \mathrm{~N}$ of nitrate in samples collected from wells 4 and 15 was 8.9 and $12.2 \%$, respectively, which indicates that nitrate in water samples from these wells originated from soil-organic nitrogen and human and/or animal wastes rather than commercial fertilizer.

\section{Vertical Distribution}

The variability of nitrate concentrations in water samples from monitoring wells screened at different depths (table 3) was examined at well sites 9 and 13 
Table 4. Nitrate concentrations in samples from monitoring wells in the study area, Nuckolls County, Nebraska, 1991-93 [mg/L, milligrams per liter]



\footnotetext{
'Year 1: April 1991 to March 1992; Year 2: April 1992 to March 1993.
} 

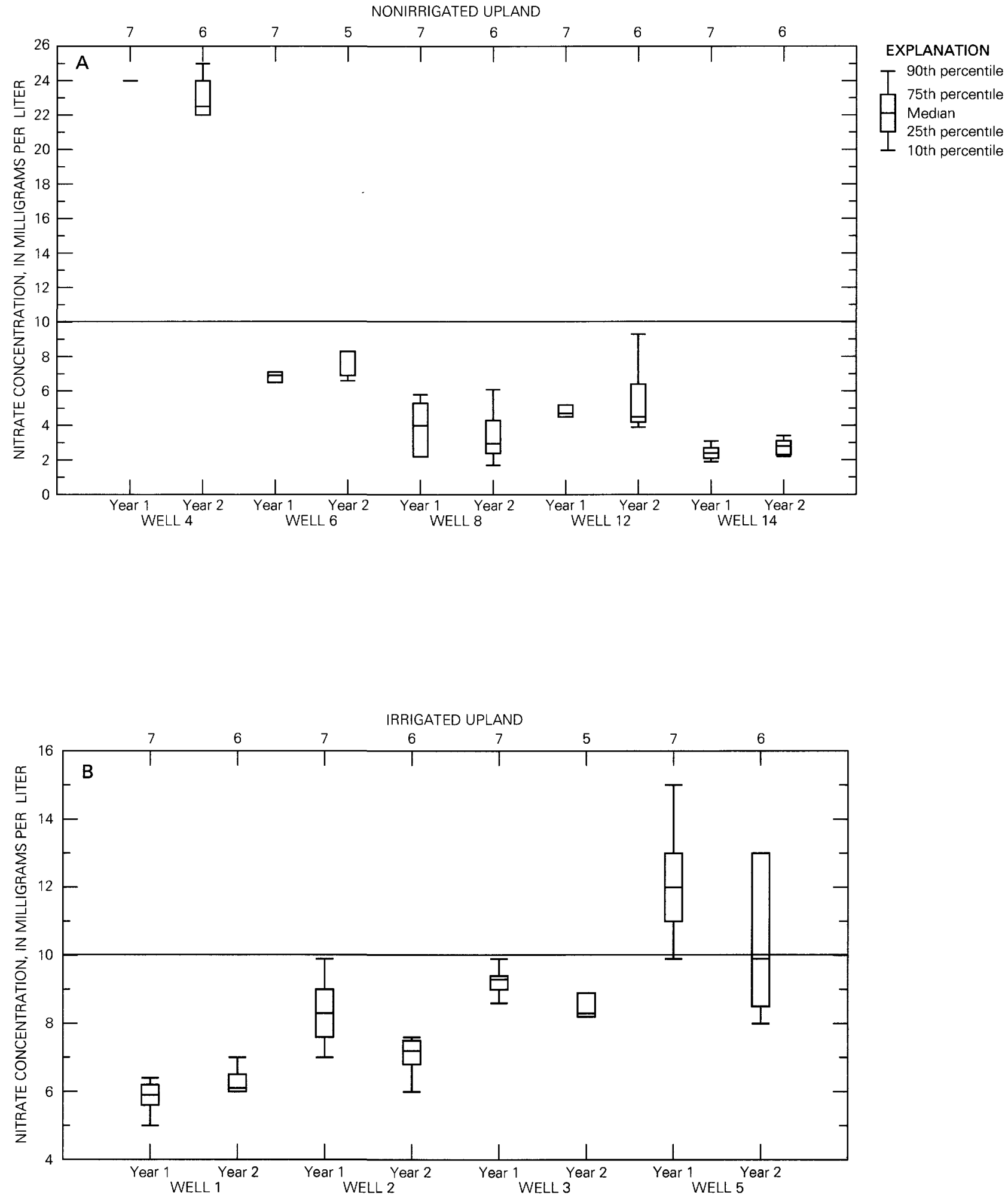

Figure 8. Nitrate concentrations from year 1 baseline data prior to the implementation of the management plan and year 2 data after implementation of the plan in the study area, Nuckolls County, Nebraska: (A) nonirrigated upland; (B) irrigated upland; (C) irrigated lowland. 


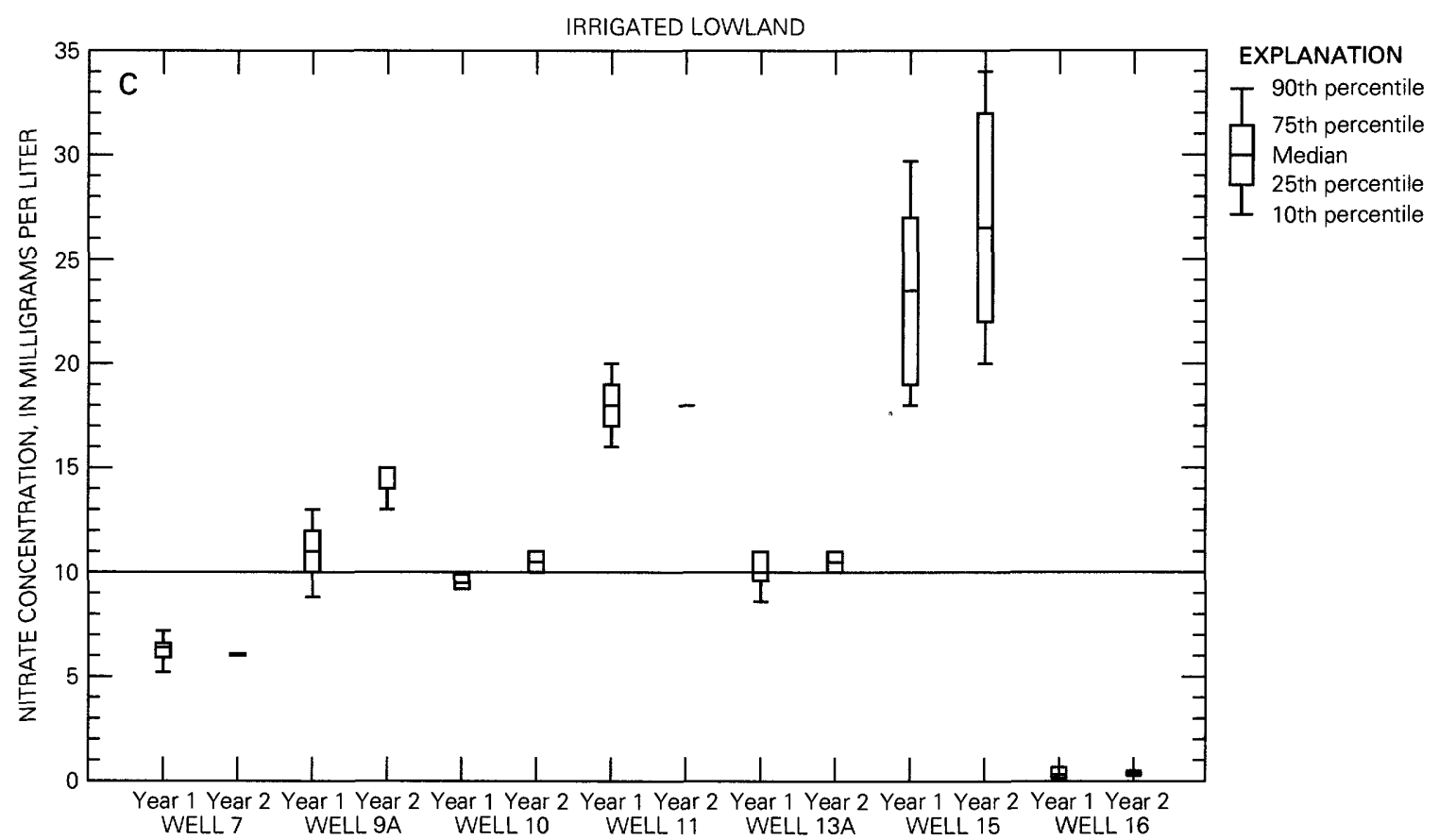

Figure 8. Nitrate concentrations from year 1 baseline data prior to the implementation of the management plan and year 2 data after implementation of the plan in the study area, Nuckolls County, Nebraska: (A) nonirrigated upland; (B) irrigated upland; and (C) irrigated lowland-Continued.

(fig. 10), which are located in the lowland area. At well 9, median nitrate concentration for year 1 was $26 \mathrm{mg} / \mathrm{L}$ in the water from the well screened at the top of the aquifer, $8.0 \mathrm{mg} / \mathrm{L}$ in water from the well screened at the bottom of the aquifer, and $11.1 \mathrm{mg} / \mathrm{L}$ in water from the well screened through the entire aquifer. Median nitrate concentrations for the three depths in year 2 were $26.2,11.3$, and $14.2 \mathrm{mg} / \mathrm{L}$, respectively. Similarly, for well 13 , the median nitrate concentrations at the three different depths were 11.7, 9.6, and $10.3 \mathrm{mg} / \mathrm{L}$ for year 1 , and $12.3,10.1$, and $10.8 \mathrm{mg} / \mathrm{L}$ for year 2 , respectively.

The observed stratification of nitrate concentration is likely the result of (1) a relatively short transit time for nitrate to leach through the shallow unsaturated zone to the water table, compared to the slower rate of ground-water flow and dispersion, and

(2) possible denitrification of nitrate at depth as conditions become more reducing.

The vertical distribution of nitrate concentrations at the nested wells demonstrates the stratification of nitrate concentrations within the aquifer. Therefore, the wells open to the entire aquifer are considered to yield samples most representative of the entire aquifer. In areas where wells are screened near the top section of the saturated zone, variations in nitrate concentrations most likely were related to short-term or seasonal differences in precipitation, irrigation recharge, and agricultural practices.

\section{Temporal Variation}

Because of slow ground-water movement and the resulting time lag between the adoption of the management plan and water-quality improvement, a comparison of nitrate concentrations at each monitoring well for years 1 and 2 shows little change (table 4, figs. 8 and 11). Examining upland and lowland areas separately, nitrate concentrations generally decreased slightly in the upland and increased slightly in the lowland (fig. 11). Changes in nitrate concentrations in the ground water are expected to be detected more quickly in the lowland area than the upland area because of the sandy-textured soils and shallow water table that are present in the lowland area. A Mann-Whitney test (Conover, 1989) indicated 

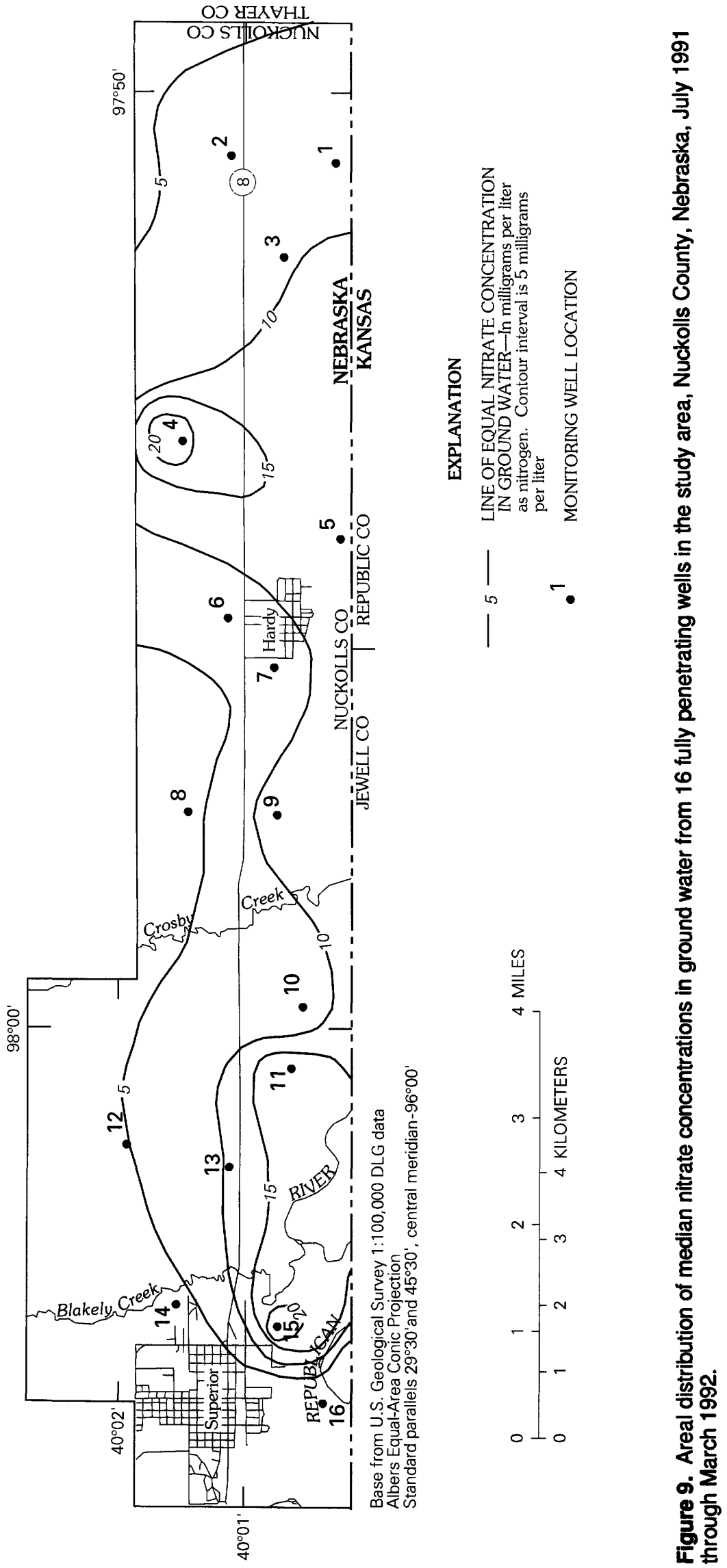


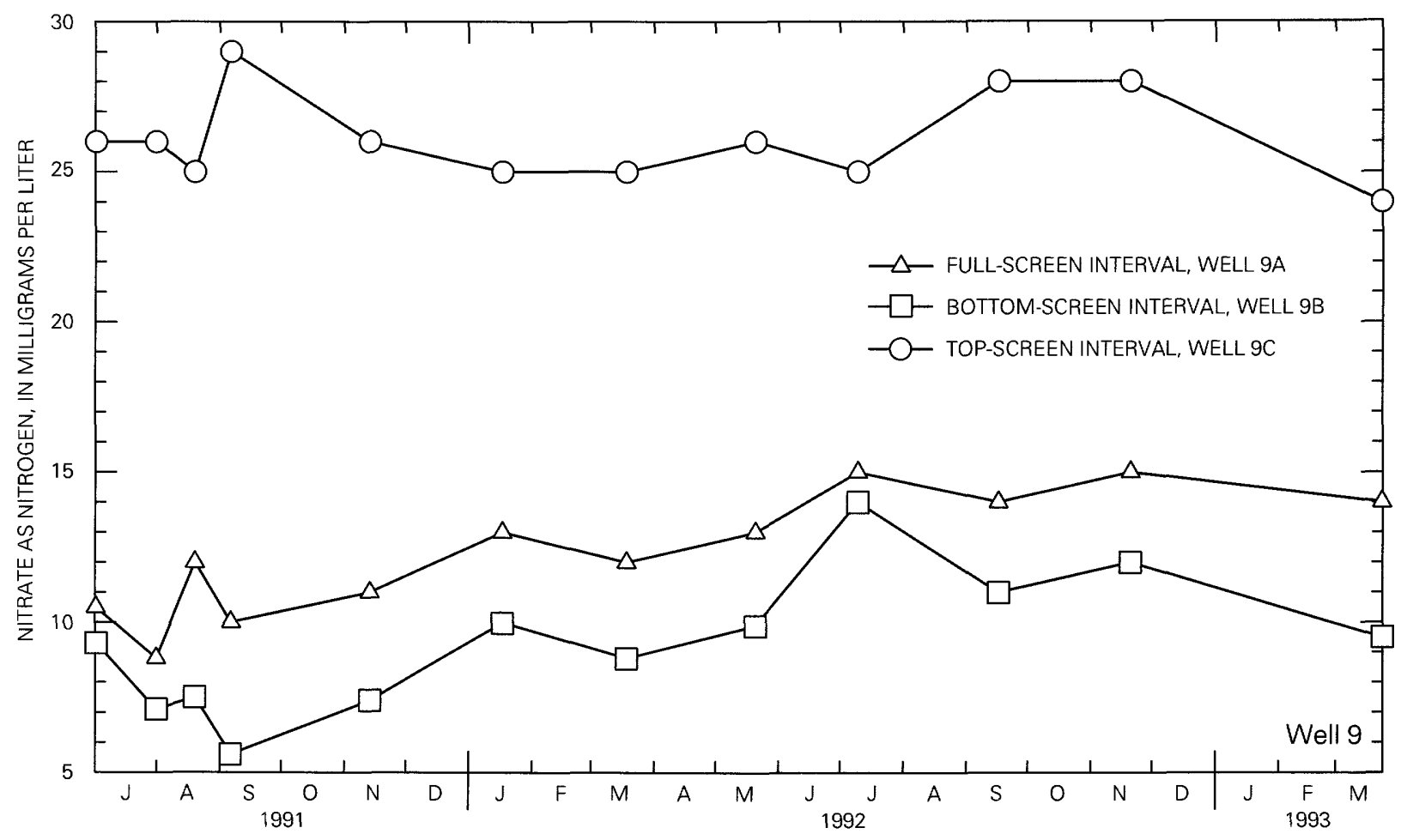

TIME, IN MONTHS

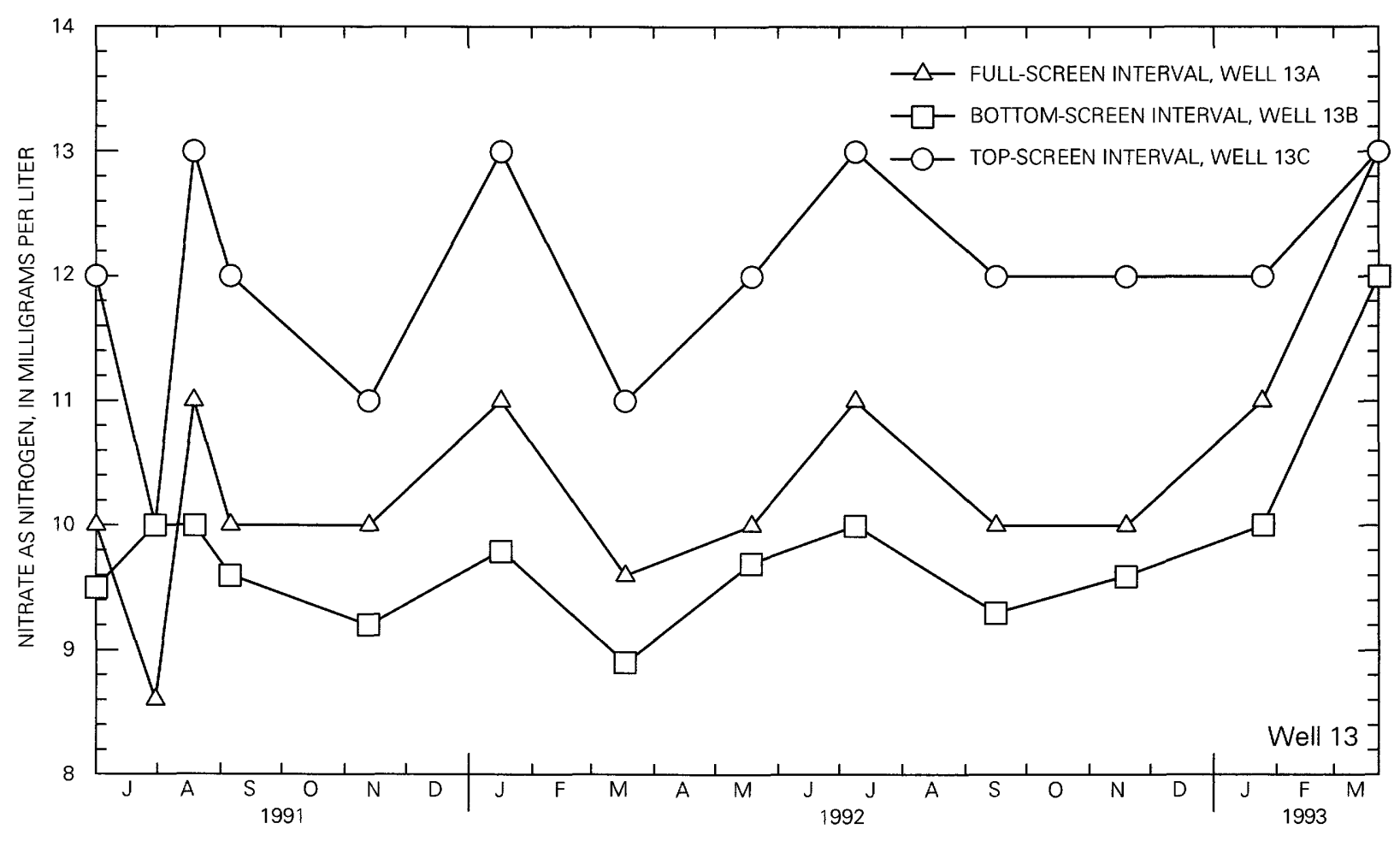

TIME, IN MONTHS

Figure 10. Stratification of nitrate concentrations in water samples from wells 9 and 13 in the study area, Nuckolls County, Nebraska, 1991-93. 


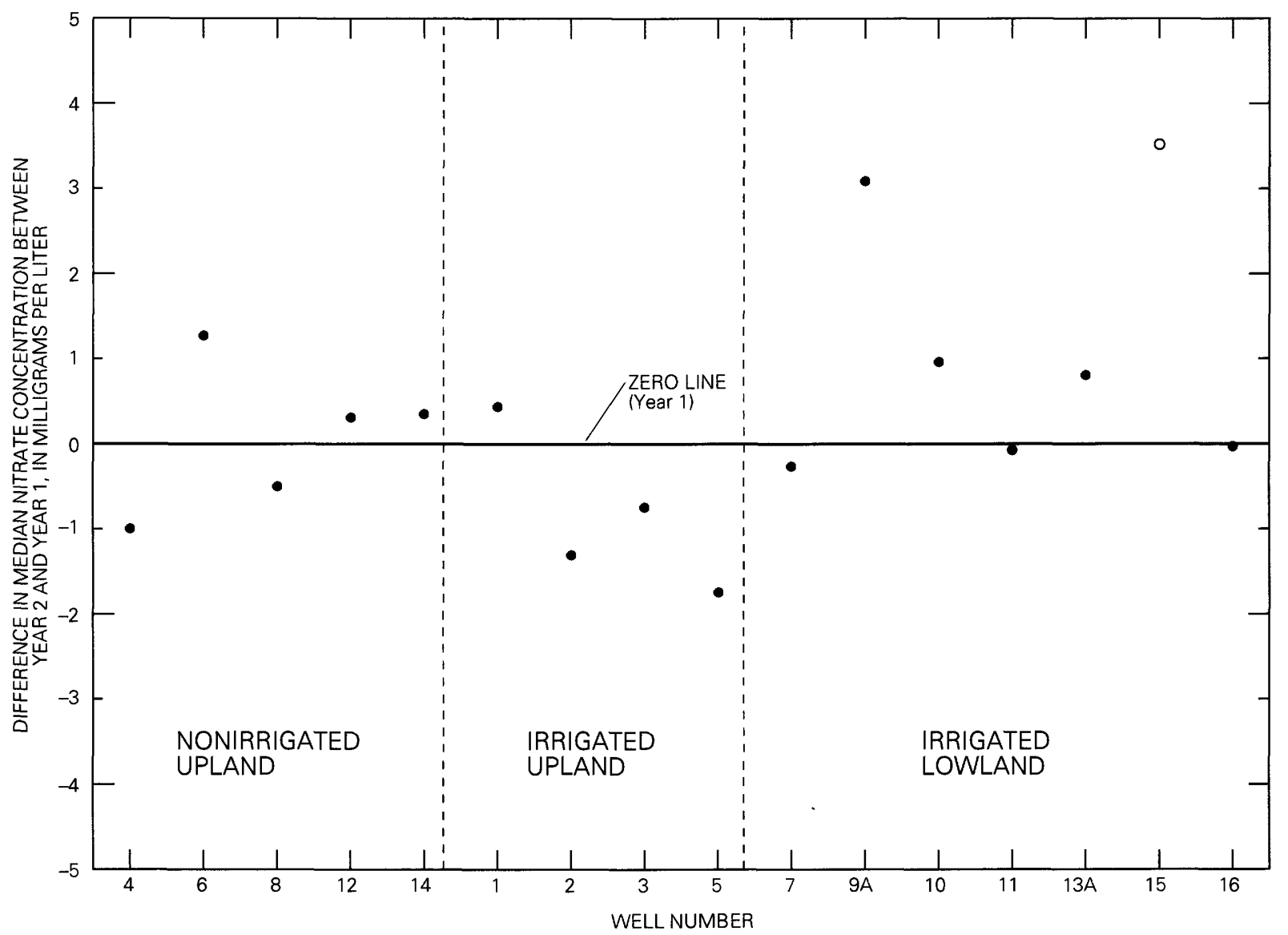

Figure 11. Difference in median nitrate concentrations between year 2 and year 1 in ground water from fully penetrating monitoring wells in the study area, Nuckolls County, Nebraska, 1991-93.

no significant difference in nitrate concentrations between the two years of data $(p=0.46)$.

The amount of variation in nitrate concentration for a 2-year period for all wells was also evaluated. This variation may be an appropriate consideration when selecting sampling times to effectively define long-term trends with fewer samples. Substantial variation in nitrate concentrations would make it more difficult to identify long-term trends. The amount of variation in nitrate concentration can be determined using: where:

$$
\begin{aligned}
& \text { SS }=\text { the sum of squares, } \\
& \mathrm{x}=\text { monthly nitrate data } \\
& \overline{\mathrm{x}}=\text { annual average concentration for a single well } \\
&\text { (table } 4) . \\
& \text { subscripts } 1 \text { and } 2 \text { indicate years } 1 \text { and } 2, \text { and } \\
& \mathrm{i}=\text { well number, } 1-16 .
\end{aligned}
$$

Based on limited (years 1 and 2) data, samples collected in January and August had the least amount of variation (table 5).

$$
\mathrm{SS}=\Sigma\left[\left(x_{1 i}-\bar{x}_{1}\right)^{2}+\left(x_{2 i}-\bar{x}_{2}\right)^{2}\right]
$$


Table 5. Summary of the sum of squares, the mean sum of squares, and its ranking for monthly nitrate concentrations in water samples from 16 wells in the study area, 1991-93

[SS, the 2-year combined sum of squares $\sum\left[\left(x_{1 i}-\bar{x}_{1}\right)^{2}+\left(x_{2 i}-\bar{x}_{2}\right)^{2}\right]$; $\mathrm{N}$, sample size; MSS, the mean sum of squares of $\mathrm{SS} / \mathrm{N}$ ]

\begin{tabular}{lrrrc}
\hline \multicolumn{1}{c}{ Month } & SS & N & MSS & Rank \\
\hline August & 9.3 & 15 & 0.6 & 1 \\
January & 51.6 & 30 & 1.7 & 2 \\
March & 66.7 & 31 & 2.2 & 3 \\
November & 71.4 & 32 & 2.2 & 4 \\
July & 92.6 & 32 & 2.9 & 5 \\
September & 96.9 & 32 & 3.0 & 6 \\
May & 53.8 & 16 & 3.4 & 7 \\
\hline
\end{tabular}

It may also be relevant to identify times during which maximum or minimum concentrations occurred. This information could indicate sampling times most likely to identify recurring seasonal extremes, which may also be useful in identifying longterm trends.

\section{Nltrate and Ammonlum in the Unsaturated Zone}

Important to the issue of monitoring programs is the nitrate content of the unsaturated zone. The amount of nitrogen present in the unsaturated zone and the rate at which it is transported to the water table determines the time required for a management plan to have an impact on nitrate concentrations in the ground water.

Most of the nitrogen applied to the field is in the form of anhydrous ammonia, which is ionized to ammonium and tends to sorb to organic matter and clay particles in the soil (Bohn and others, 1985). Nitrification within the soil zone converts most of the ammonia to nitrate that is highly mobile under aerobic conditions and is leached by recharge water downward toward the water table. Tables 11-20 at the back of the report contain the basic data of organic matter and silt-clay content and nitrate and ammonium concentrations derived from sediment cores.

\section{Vertical Distribution and Change In Nitrogen Content}

The mean organic matter, nitrate and ammonium concentrations as nitrogen, and mean silt-clay content from analyses of replicate sediment cores at two monitoring sites ( 1 and 9) for 3 consecutive years
(1991-93) are presented in tables 6 and 7. Distribution patterns of these constituents with depth in the sediment profile are depicted in figures 12 and 13 .

Small concentrations of nitrate and ammonium, with overall means of 1.6 and $2.5 \mathrm{mg} / \mathrm{kg}(\mathrm{mg} / \mathrm{L})$ for site 1 , and 2.4 and $2.0 \mathrm{mg} / \mathrm{kg}$ for site 9 , were found in the unsaturated zone (tables 6-7). Although nitrate concentrations in the unsaturated zone are small compared to those in ground water, leaching over time is apparently sufficient to increase the nitrate concentrations in ground water to relatively high levels. Maximum concentrations of nitrate were detected at or within $13 \mathrm{ft}$ of the land surface in both sites, suggesting that the major source of nitrogen at these sites is from the surface. When correlating nitrate, ammonium, organic matter, and silt-clay content with depth for all sediment samples at site 1 , the correlations ranging from 0.40 to 0.69 show that nitrate concentrations, organic matter, and silt-clay content decreased with depth, whereas, ammonium increased with depth. Likewise, at site 9, ammonium concentrations and organic matter decreased with depth, whereas the nitrate concentrations and silt-clay content seemed to be independent of depth. An estimation of nitrate and ammonium contents in the unsaturated zone for 3 consecutive years at sites 1 and 9 is summarized in table 8. Distribution patterns and changes with depth in the sediment profile at sites 1 and 9 are depicted in figures 14 and 15.

At site 1, total nitrate and ammonium content of the unsaturated zone was 25 percent less for spring 1992 compared to spring 1991 contents. The total nitrate and ammonium content in spring 1993 at site 1 showed no change compared to spring 1991. At site 9 , nitrate and ammonium content of the unsaturated zone at site 9 was $444 \mathrm{lb} /$ acre in spring 1991, $228 \mathrm{lb} / \mathrm{acre}$ (48 percent less compared to spring 1991) in spring 1992, and $271 \mathrm{lb} /$ acre (39 percent compared to 1991) in spring 1993.

\section{Estimation of Rate of Vertical Transport of Nitrate}

Tracer experiments were conducted to estimate the annual rate of movement of nitrate in the unsaturated zone and to estimate the retention rate of nitrate in the unsaturated zone. Bromide was applied on two irrigated corn-field plots (sites 1 and 9) prior to fertilizer application in the spring 1992. The background levels of bromide concentration at the two sites prior to bromide treatment (February 4, 1992) were less 
Table 6. Mean organic-matter content, silt-clay content, and ammonium and nitrate concentrations as nitrogen in multiple sediment cores for site 1 in the study area, Nuckolls County, Nebraska, spring 1991-93

[--, no data; $\mathrm{mg} / \mathrm{kg}$, milligrams per kilogram; silt-clay, grain size $<0.063$ millimeter]

\begin{tabular}{|c|c|c|c|c|c|c|c|c|c|}
\hline \multirow{2}{*}{$\begin{array}{l}\text { Sample } \\
\text { depth } \\
\text { (feet) }\end{array}$} & \multicolumn{2}{|c|}{$\begin{array}{l}\text { Organic matter } \\
\text { (percent) }\end{array}$} & \multirow{2}{*}{$\begin{array}{c}\begin{array}{c}\text { Silt-clay } \\
\text { content } \\
\text { (percent) }\end{array} \\
1991\end{array}$} & \multicolumn{3}{|c|}{$\begin{array}{l}\text { Nitrate as nltrogen } \\
(\mathbf{m g} / \mathbf{k g})\end{array}$} & \multicolumn{3}{|c|}{$\begin{array}{c}\text { Ammonlum as nltrogen } \\
(\mathbf{m g} / \mathbf{k g})\end{array}$} \\
\hline & 1992 & 1993 & & 1991 & 1992 & 1993 & 1991 & 1992 & 1993 \\
\hline 0.3 & 2.28 & 1.44 & 77.8 & -- & 2.36 & 2.28 & 2.29 & 1.65 & 1.93 \\
\hline 3.0 & .37 & .90 & 70.1 & 1.98 & 4.08 & 3.36 & 1.74 & 1.31 & 1.92 \\
\hline 6.0 & .20 & .21 & 75.2 & 1.73 & 1.37 & 4.14 & 1.80 & 1.40 & 1.86 \\
\hline 9.0 & .22 & .46 & 68.2 & 2.16 & 1.37 & 1.91 & 1.95 & .63 & 1.30 \\
\hline 11.4 & 1.11 & .58 & 68.7 & 2.55 & 2.01 & 2.31 & 1.86 & .56 & 3.78 \\
\hline 13.0 & .99 & .82 & 51.7 & 2.58 & 1.93 & 1.77 & 1.43 & .77 & 1.17 \\
\hline 16.0 & .39 & .36 & 50.5 & 2.42 & 1.52 & 1.27 & 1.61 & .87 & 1.45 \\
\hline 19.0 & .16 & .22 & 63.4 & 2.14 & 1.33 & 1.34 & 2.63 & 1.17 & 1.90 \\
\hline 22.0 & .14 & .16 & 64.6 & 2.19 & 1.25 & 1.25 & 2.57 & 1.52 & 2.20 \\
\hline 25.0 & .16 & .15 & 58.1 & 1.96 & 1.78 & 1.25 & 2.26 & 1.82 & 2.53 \\
\hline 28.0 & .18 & .16 & 52.9 & 1.37 & 1.68 & 1.40 & 2.97 & 1.51 & 1.66 \\
\hline 31.0 & .10 & .12 & 59.2 & 1.68 & 1.20 & 1.47 & 3.12 & 1.58 & 2.35 \\
\hline 34.0 & .12 & .10 & 62.7 & 1.94 & 1.30 & 1.63 & 3.56 & 2.32 & 2.26 \\
\hline 37.0 & .10 & .07 & 45.3 & 2.22 & 1.36 & 2.49 & 3.27 & 1.77 & 2.47 \\
\hline 41.0 & .07 & .09 & 63.5 & 1.75 & 1.09 & 1.52 & 2.54 & 1.70 & 2.90 \\
\hline 43.0 & .09 & .12 & 68.5 & 2.04 & 1.51 & 1.84 & 3.09 & 1.74 & 2.59 \\
\hline 46.0 & .14 & .12 & 60.3 & 2.09 & .83 & 1.49 & 2.67 & 2.02 & 3.43 \\
\hline 49.0 & .13 & .10 & 42.3 & 1.98 & 1.61 & 1.44 & 2.60 & 2.45 & 3.36 \\
\hline 51.3 & .09 & .12 & 54.8 & 1.49 & 1.15 & 1.76 & 2.69 & 2.60 & 3.33 \\
\hline 52.0 & .11 & .12 & 82.2 & 1.29 & .93 & 1.55 & 3.00 & 2.35 & 2.39 \\
\hline 55.0 & .11 & .16 & 81.9 & 1.70 & 1.16 & 1.59 & 2.75 & 3.12 & 3.54 \\
\hline 56.0 & .15 & .17 & 48.7 & 1.42 & 1.15 & 1.63 & 3.52 & 3.21 & 3.91 \\
\hline 58.0 & .13 & .12 & 68.6 & 1.42 & 1.31 & 1.47 & 1.80 & 3.00 & 3.14 \\
\hline 62.0 & .12 & .14 & 33.6 & 2.06 & .91 & 1.47 & 5.21 & 3.04 & 3.76 \\
\hline 64.0 & .09 & .09 & 35.1 & 1.93 & .70 & .92 & 4.45 & 3.71 & 3.29 \\
\hline 65.0 & .07 & .12 & 42.7 & 1.68 & .70 & 1.36 & 4.94 & 2.96 & 3.03 \\
\hline 68.0 & .23 & .13 & 46.6 & 1.24 & .53 & 1.50 & 2.32 & 3.53 & 3.83 \\
\hline 70.0 & .05 & .07 & 47.5 & 1.29 & .51 & 1.48 & 2.13 & 2.17 & 3.22 \\
\hline 73.0 & .04 & .11 & 40.1 & 1.34 & .53 & 1.58 & 2.63 & 1.53 & 4.44 \\
\hline
\end{tabular}


Table 7. Mean organic-matter content, silt-clay content, and ammonium and nitrate concentrations as nitrogen in multiple sediment cores for site 9 in the study area, Nuckolls County, Nebraska, spring 1991-93

[--, no data; $\mathrm{mg} / \mathrm{kg}$, milligrams per kilogram; silt-clay grain size $<0.063$ millimeter $]$

\begin{tabular}{|c|c|c|c|c|c|c|c|c|c|}
\hline \multirow{2}{*}{$\begin{array}{l}\text { Sample depth } \\
\text { (feet) }\end{array}$} & \multicolumn{2}{|c|}{$\begin{array}{c}\text { Organic matter } \\
\text { (percent) }\end{array}$} & \multirow{2}{*}{$\begin{array}{c}\begin{array}{c}\text { Silt-clay } \\
\text { content } \\
\text { (percent) }\end{array} \\
1991\end{array}$} & \multicolumn{3}{|c|}{$\begin{array}{l}\text { Nitrate as nitrogen } \\
(\mathbf{m g} / \mathrm{kg})\end{array}$} & \multicolumn{3}{|c|}{$\begin{array}{c}\text { Ammonium as nitrogen } \\
(\mathrm{mg} / \mathrm{kg})\end{array}$} \\
\hline & 1992 & 1993 & & 1991 & 1992 & 1993 & 1991 & 1992 & 1993 \\
\hline 0.3 & 1.94 & 1.67 & 57.8 & 5.50 & 2.28 & 1.86 & 2.17 & 1.73 & 2.34 \\
\hline 2.0 & 1.05 & 0.97 & 44.1 & 1.78 & 1.88 & 1.09 & 2.47 & 2.14 & 3.38 \\
\hline 3.0 & .48 & .48 & 53.1 & 1.26 & 1.24 & .93 & 2.53 & 2.24 & 3.97 \\
\hline 5.0 & .50 & .36 & 38.8 & 2.81 & 1.08 & 1.09 & 1.32 & 1.60 & 3.68 \\
\hline 7.0 & .54 & .45 & 45.0 & 6.65 & 1.22 & 1.17 & 1.23 & 1.40 & 2.19 \\
\hline 9.0 & .25 & .35 & 57.4 & 8.40 & 1.39 & 1.30 & 2.10 & 1.51 & 2.35 \\
\hline 11.0 & .21 & .22 & 78.7 & 9.78 & 1.91 & 1.14 & 1.75 & 1.53 & 1.76 \\
\hline 13.0 & .22 & .20 & 44.3 & 5.00 & 1.41 & 1.30 & 1.35 & 1.49 & 1.67 \\
\hline 15.0 & .18 & .19 & 58.4 & 2.64 & 1.53 & 1.40 & 2.28 & 1.25 & 1.90 \\
\hline 17.0 & .31 & .19 & 60.0 & 2.45 & 1.69 & 1.70 & 2.08 & 1.29 & 2.00 \\
\hline 18.6 & .41 & .35 & 31.3 & 2.32 & 2.19 & 1.45 & 1.61 & 1.53 & 2.51 \\
\hline 19.0 & .46 & .42 & 33.7 & 2.04 & 1.74 & 1.50 & 1.11 & .89 & 2.24 \\
\hline 20.0 & .42 & .44 & -- & -- & 1.71 & 1.47 & -- & 1.11 & 2.62 \\
\hline
\end{tabular}

than the analytical detection limit of $0.4 \mathrm{mg} / \mathrm{kg}$

(tables 9 and 10).

Bromide in sediment cores that were obtained 343 days (April 27, 1993) after bromide application indicate that the tracer had leached to $9 \mathrm{ft}$ (core 3) and $13 \mathrm{ft}$ (core 1) below the land surface at sites 1 and 9 , respectively (tables 9 and 10).

Assuming transport of the conservative bromide tracer in the unsaturated zone is similar to that of nitrate, and assuming an annual rate of downward movement of $11 \mathrm{ft}$, it would take about 2 years for nitrate to travel through a 22 -ft-thick unsaturated zone in the lowland and reach ground water. However, in parts of the upland where thickness of the unsaturated zone is greater than $100 \mathrm{ft}$, it would take more than 9 years for nitrate to reach ground water. Total bromide retained in the unsaturated zone was considerably less than the level of bromide applied. The bromide within the unsaturated zones was estimated to be about 28 percent of the amount applied at site 1 and 19 percent at site 9 . However, about 46 and 91 percent of those amounts were retained in 5- $\mathrm{ft}$ unsaturated zones at sites 1 and 9, respectively. A large portion of bromide probably was removed by runoff and uptake by the corn plants (P.L. Barnes, Kansas State University Agronomy Department, written commun., 1993). 
SILT AND CLAY CONTENT, IN PERCENT

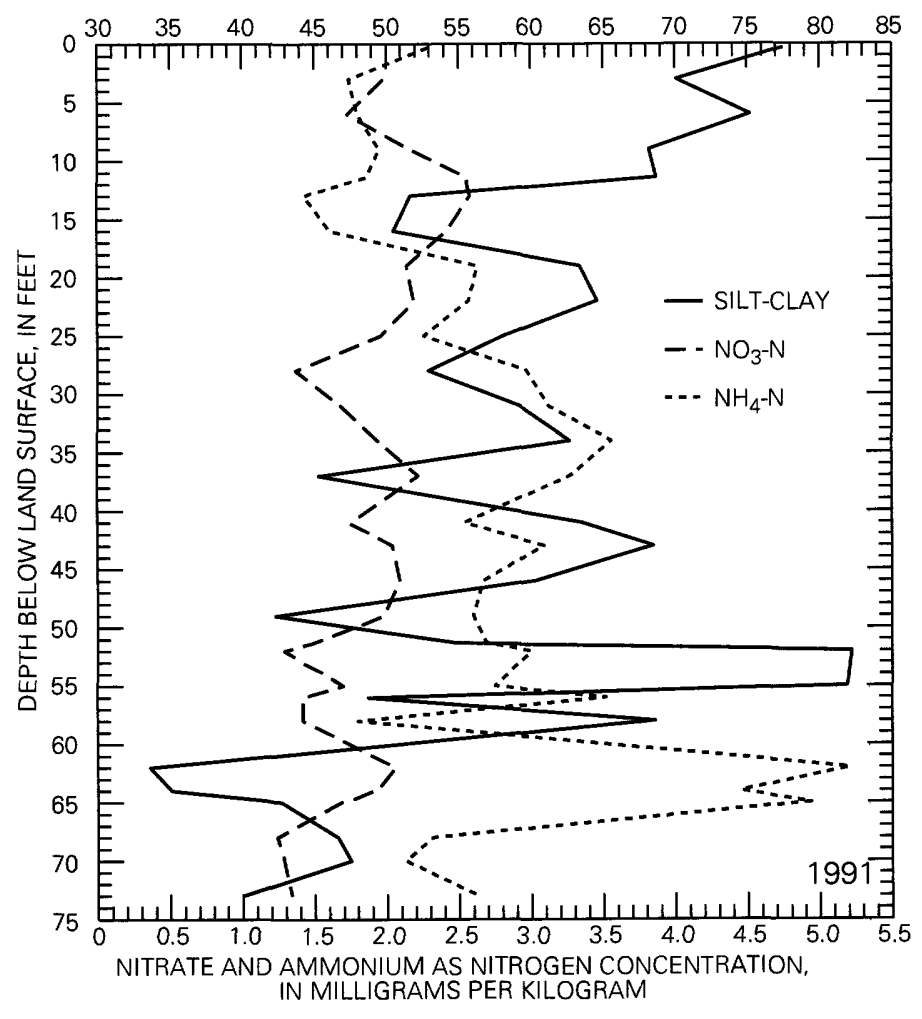

Figure 12A. Distribution of ammonium and nitrate concentrations and organic matter and silt-clay content with depth at site 1 of the study area, Nuckolls County, Nebraska, spring 1991.

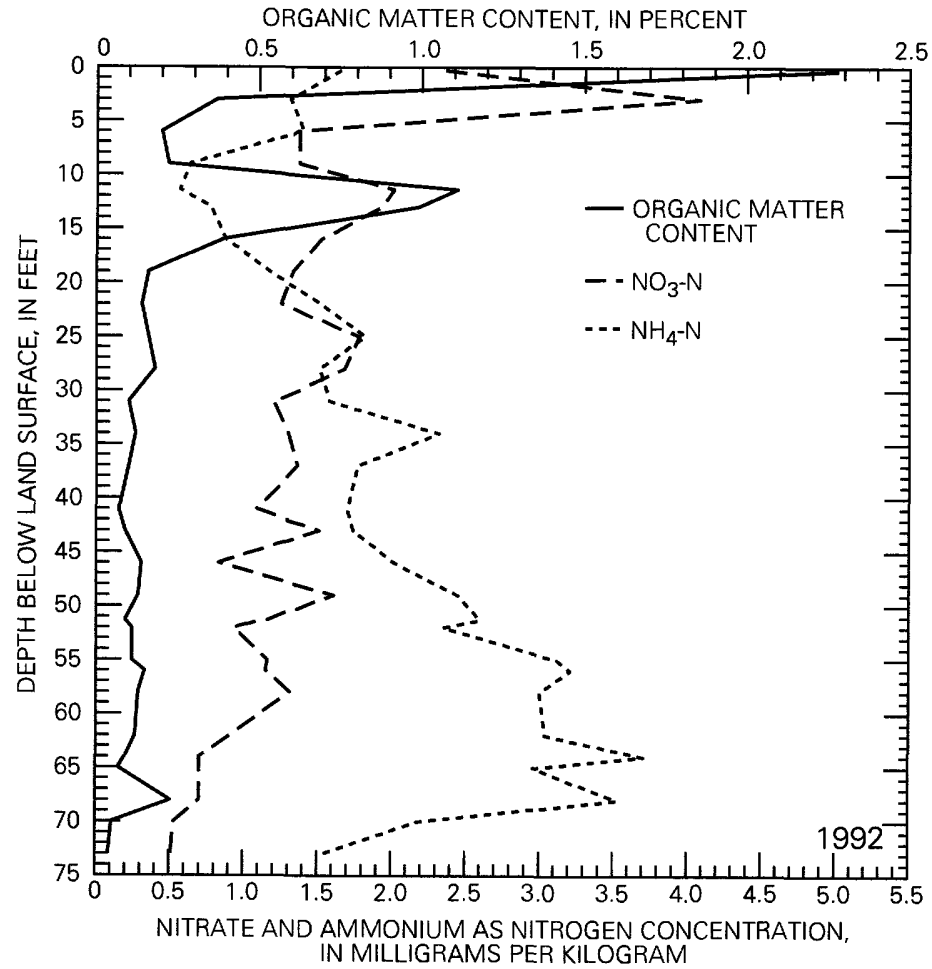

Figure 12B. Distribution of ammonium and nitrate concentrations and organic matter and silt-clay content with depth at site 1 of the study area, Nuckolls County, Nebraska, spring 1992. 


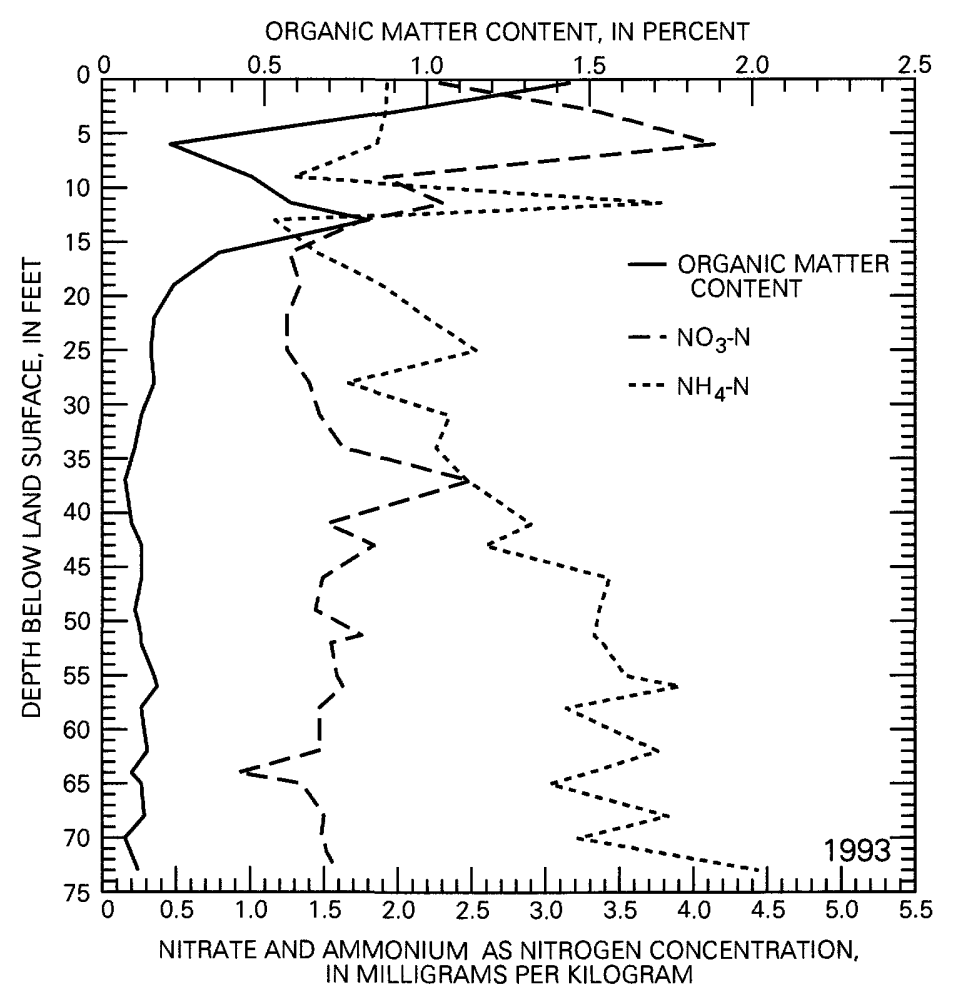

Figure 12C. Distribution of ammonium and nitrate concentrations and organic matter and silt-clay content with depth at site 1 of the study area, Nuckolls County, Nebraska, spring 1993. 


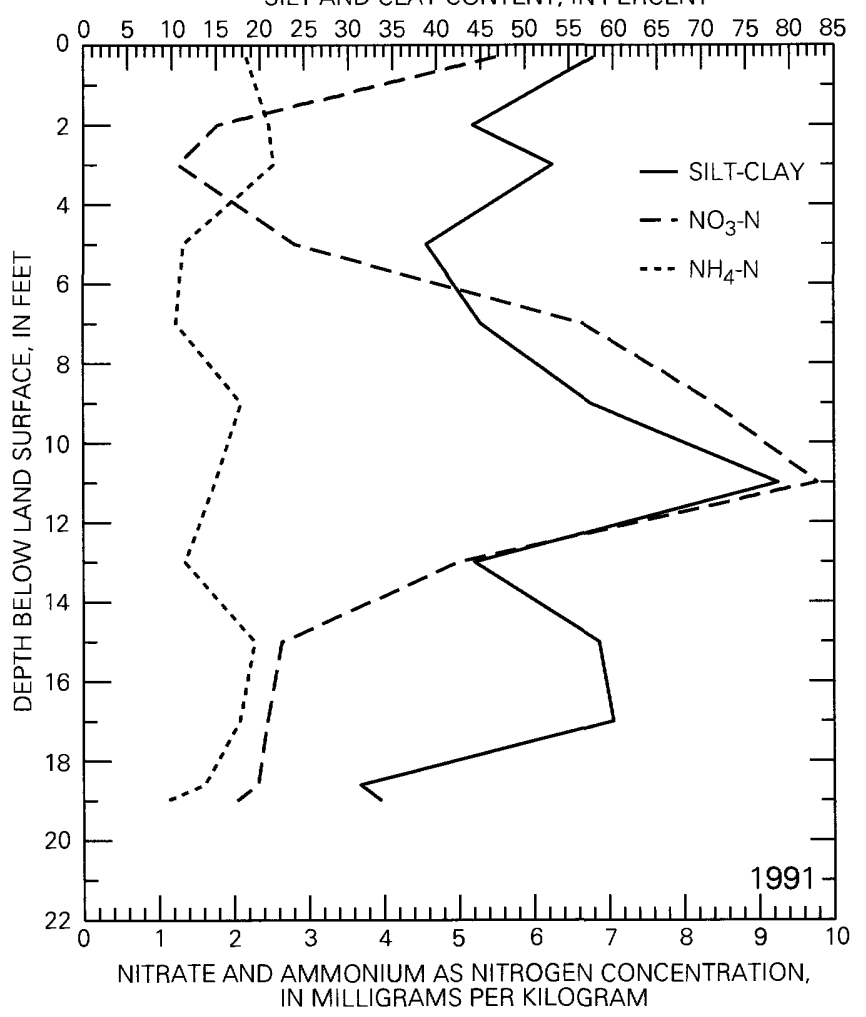

Figure 13A. Distribution of ammonium and nitrate concentrations and organic matter and silt-clay content with depth at site 9 of the study area, Nuckolls County, Nebraska, spring 1991.

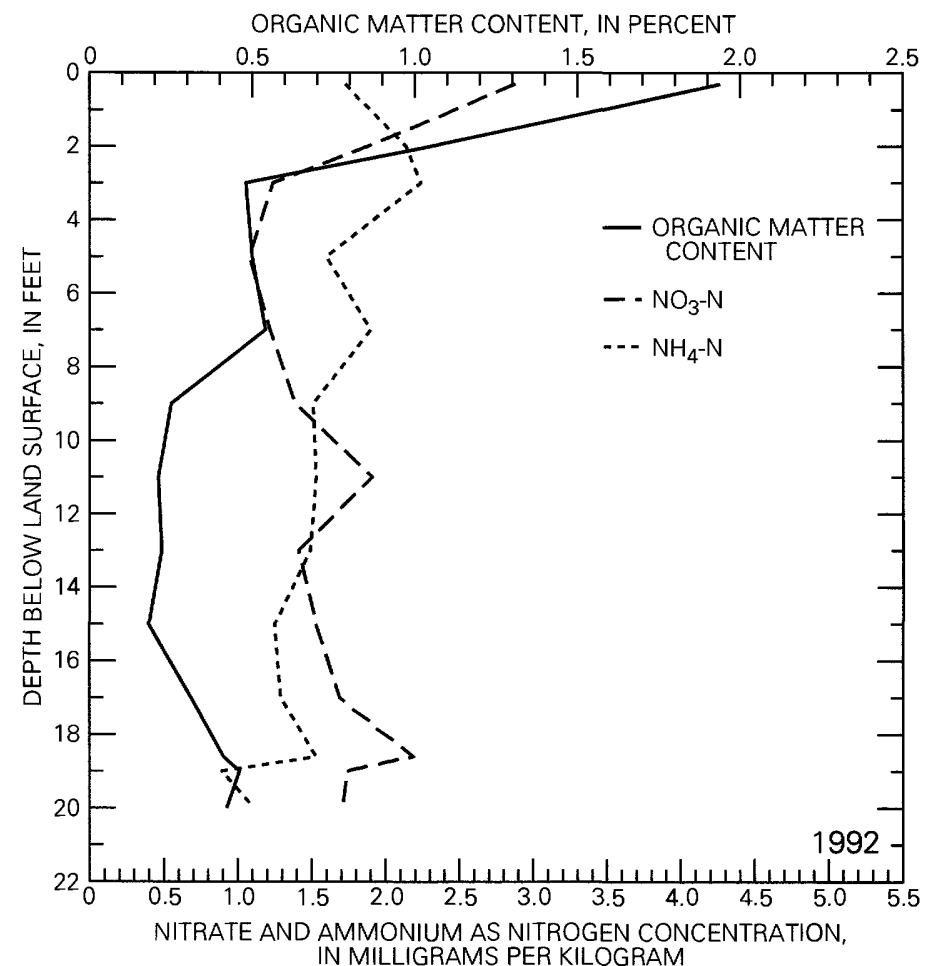

Figure 13B. Distribution of ammonium and nitrate concentrations and organic matter and silt-clay content with depth at site 9 of the study area, Nuckolls County, Nebraska, spring 1992. 




Figure 13C. Distribution of ammonium and nitrate concentrations and organic matter and silt-clay content with depth at site 9 of the study area, Nuckolls County, Nebraska, spring 1993.

Tabie 8. Summary of nitrate and ammonium contents in the unsaturated zone, sites 1 and 9 in the study area, Nuckolls County, Nebraska, spring 1991-93

[lb/acre, pounds per acre; total sample depths are 73 and 20 feet below land surface at sites 1 and 9, respectively]

\begin{tabular}{cccccccc}
\hline Nitrogen & \multicolumn{3}{c}{ Site 1 } & & \multicolumn{3}{c}{ Site 9 } \\
\cline { 2 - 5 } \cline { 6 - 7 } compound & 1991 & 1992 & 1993 & & 1991 & 1992 & 1993 \\
\hline $\begin{array}{c}\text { Nitrate as } \\
\text { nitrogen, } \\
\text { lb/acre }\end{array}$ & 484 & 370 & 467 & 314 & 113 & 92 \\
$\begin{array}{c}\text { Ammon- } \\
\text { ium as } \\
\text { nitrogen, } \\
\text { lb/acre }\end{array}$ & 682 & 507 & 699 & 130 & 115 & 179 \\
Total & 1,166 & 877 & 1,166 & 444 & 228 & 271 \\
\hline
\end{tabular}




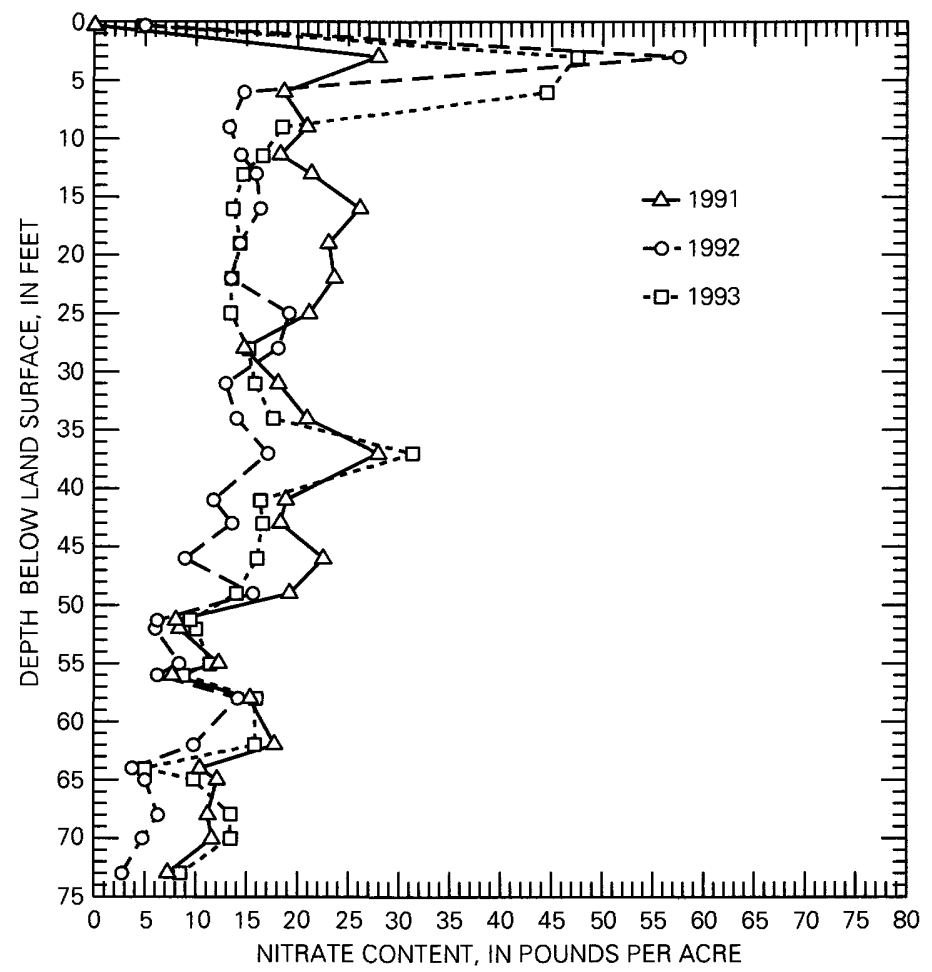

Figure 14A. Nitrate content and total nitrogen and ammonium content beneath a corn field at site 1 in the study area, Nuckolls County, Nebraska, spring 1991-93.

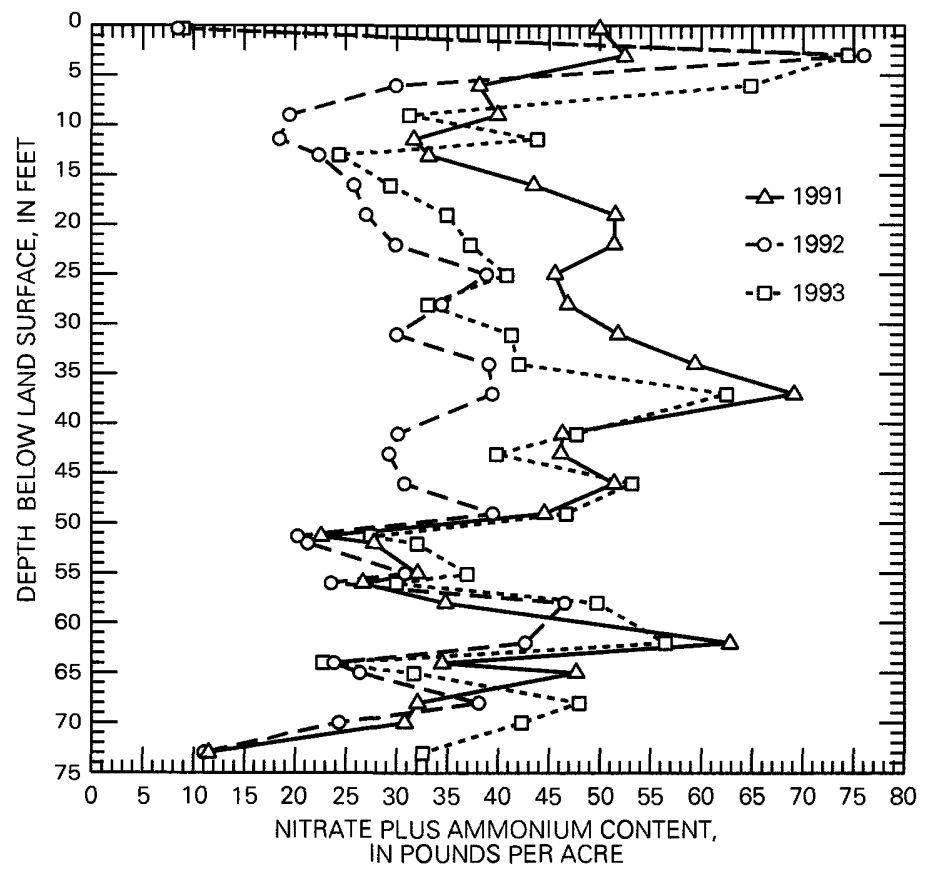

Figure 14B. Nitrate content and total nitrogen and ammonium content beneath a corn field at site 1 in the study area, Nuckolls County, Nebraska, spring 1991-93. 


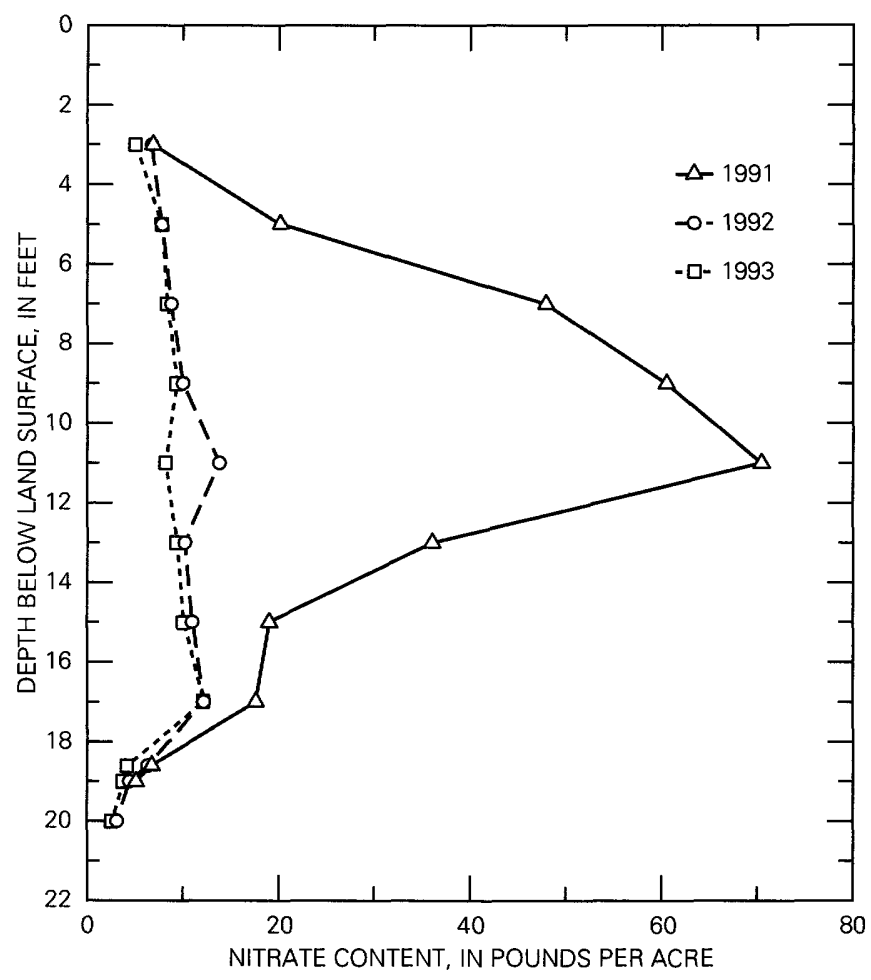

Figure 15A. Nitrate content and nitrate and ammonium content beneath a corn field at site 9 in the study area, Nuckolls County, Nebraska, spring 1991-93.



Figure 15B. Nitrate content and nitrate and ammonium content beneath a corn field at site 9 in the study area, Nuckolls County, Nebraska, spring 1991-93. 
Tabie 9. Concentrations of bromide in sediment cores and estimated content for site 1 in the study area, Nuckolls County, Nebraska, winter 1992 and spring 1993

[lb/acre, pounds per acre; $\mathrm{N}$, less than detection level of $0.4 \mathrm{mg} / \mathrm{kg} ; \mathrm{mg} / \mathrm{kg}$, milligrams per kilogram]

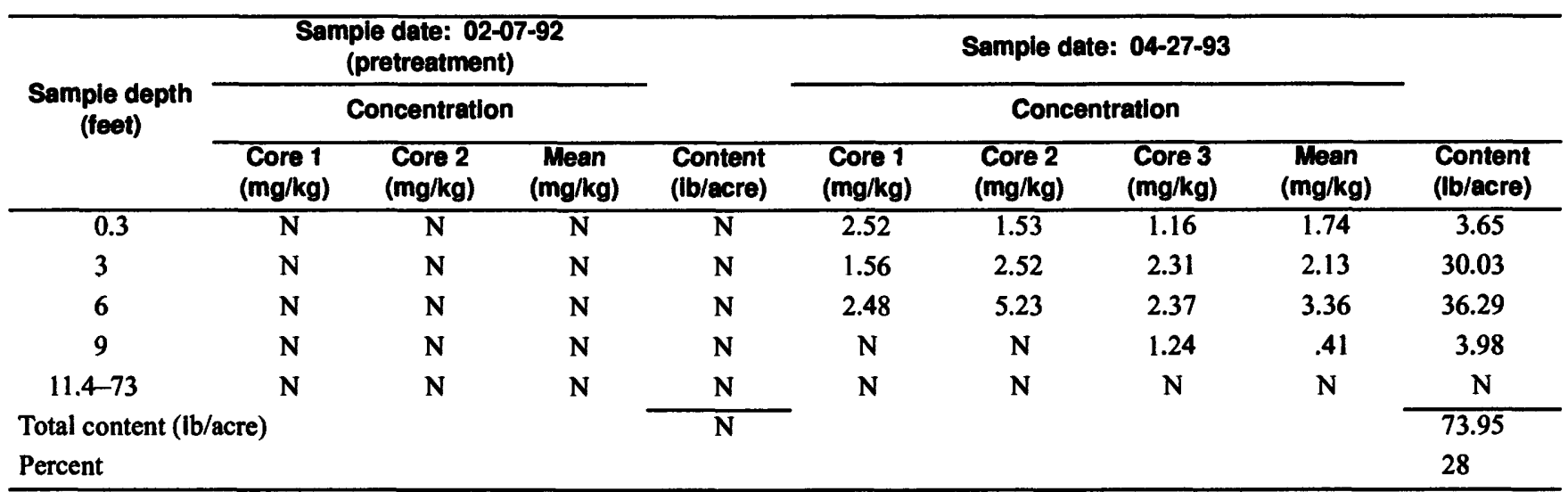

Table 10. Concentrations of bromide in sediment cores and estimated content for site 9 in the study area, Nuckolls County, Nebraska, winter 1992 and spring 1993

[lb/acre, pound per acre; $\mathrm{mg} / \mathrm{kg}$, milligrams per kilogram; $\mathrm{N}$, less than detection level of $0.4 \mathrm{mg} / \mathrm{kg}$ ]

\begin{tabular}{|c|c|c|c|c|c|c|c|c|c|}
\hline \multirow{3}{*}{$\begin{array}{l}\text { Sample } \\
\text { depth } \\
\text { (feet) }\end{array}$} & \multirow{2}{*}{\multicolumn{3}{|c|}{$\begin{array}{c}\begin{array}{c}\text { Sampie date: 02-04-92 } \\
\text { (pretreatment) }\end{array} \\
\text { Concentration }\end{array}$}} & \multicolumn{6}{|c|}{ Sample date: 04-27-93 } \\
\hline & & & & \multirow[b]{2}{*}{$\begin{array}{l}\text { Content } \\
\text { (ib/acre) }\end{array}$} & \multicolumn{4}{|c|}{ Concentration } & \multirow[b]{2}{*}{$\begin{array}{l}\text { Conten } \\
\text { (Ib/acre }\end{array}$} \\
\hline & $\begin{array}{c}\text { Core 1 } \\
\text { (mg/kg) }\end{array}$ & $\begin{array}{c}\text { Core 2 } \\
\text { (mg/kg) }\end{array}$ & $\begin{array}{c}\text { Mean } \\
\text { (mg/kg) }\end{array}$ & & $\begin{array}{c}\text { Core 1 } \\
\text { (mg/kg) }\end{array}$ & $\begin{array}{c}\text { Core 2 } \\
\text { (mg/kg) }\end{array}$ & $\begin{array}{c}\text { Core 3 } \\
\text { (mg/kg) }\end{array}$ & $\begin{array}{c}\text { Mean } \\
(\mathrm{mg} / \mathrm{kg})\end{array}$ & \\
\hline 0.3 & $\overline{\mathbf{N}}$ & $\bar{N}$ & $\mathbf{N}$ & $\overline{\mathbf{N}}$ & $\overline{\mathbf{N}}$ & 0.527 & 0.68 & $\overline{0.42}$ & 0.88 \\
\hline 2 & $\mathbf{N}$ & $\mathbf{N}$ & $\mathbf{N}$ & $\mathbf{N}$ & 4.71 & 8.27 & .60 & 4.53 & 31.26 \\
\hline 3 & $\mathbf{N}$ & $\mathbf{N}$ & $\mathbf{N}$ & $\mathbf{N}$ & 1.76 & 4.31 & .93 & 2.33 & 12.58 \\
\hline 5 & $\mathbf{N}$ & $\mathbf{N}$ & $\mathbf{N}$ & $\mathbf{N}$ & $\mathbf{N}$ & .43 & .43 & .29 & 2.09 \\
\hline 7 & $\mathbf{N}$ & $\mathrm{N}$ & $\mathbf{N}$ & $\mathbf{N}$ & $\mathbf{N}$ & $\mathrm{N}$ & .40 & .13 & .94 \\
\hline 9 & $\mathbf{N}$ & $\mathbf{N}$ & $\mathbf{N}$ & $\mathbf{N}$ & $\mathbf{N}$ & $\mathbf{N}$ & .42 & .14 & 1.01 \\
\hline 11 & $\mathbf{N}$ & $\mathbf{N}$ & $\mathbf{N}$ & $\mathbf{N}$ & $\mathbf{N}$ & $\mathrm{N}$ & $\mathbf{N}$ & $\mathbf{N}$ & $\mathbf{N}$ \\
\hline 13 & $\mathbf{N}$ & $\mathrm{N}$ & $\mathbf{N}$ & $\mathbf{N}$ & .63 & $\mathbf{N}$ & $\mathbf{N}$ & .21 & 1.51 \\
\hline $15-20$ & $\mathbf{N}$ & $\mathbf{N}$ & $\mathbf{N}$ & $\mathbf{N}$ & $\mathbf{N}$ & $\mathbf{N}$ & $\mathbf{N}$ & $\mathbf{N}$ & $\mathbf{N}$ \\
\hline \multicolumn{2}{|c|}{ Total content (lb/acre) } & & & $\overline{\mathbf{N}}$ & & & & & 50.27 \\
\hline Percent & & & & & & & & & 19 \\
\hline
\end{tabular}




\section{SUMMARY}

During the late 1980's, nitrate concentrations in ground water in excess of the U.S. Environmental Protection Agency's Maximum Contaminant Level for drinking water of 10 milligrams per liter occurred in the southern part of Nuckolls County, Nebraska. To help reduce this local ground-water contamination, the Nebraska Department of Environmental Quality designated the State's first Special Protection Area in 1989 - the Superior-Hardy Special Protection Area.

The Special Protection Area designation requires that a management plan be implemented and that concentrations of nitrate in the ground water be monitored during the 10-year period of designation as a Special Protection Area.

A ground-water-quality monitoring network of 20 wells located at 16 sites was established in 1991, in the 32-square-mile Superior-Hardy Special Protection Area. The purpose of this network was to monitor long-term trends in concentrations of nitrate in ground water after a management plan was implemented in 1991. The 16 sites were selected based on geologic, hydrogeologic, soil, land-use, and physiographic factors, cost considerations, and accessibility. Nested monitoring wells were installed at two sites (wells 9 and 13) to examine vertical distribution of nitrate concentrations in the area.

Nitrate concentrations greater than $5 \mathrm{mg} / \mathrm{L}$ were detected in 81 percent of the ground-water samples collected from the shallow aquifer during 1991-93. Approximately 44 percent of the samples exceeded $10 \mathrm{mg} / \mathrm{L}$, the U.S. Environmental Protection Agency Maximum Contaminant Level for nitrate as nitrogen in drinking water. The mobility of nitrate in the ground-water system was demonstrated by detection of high nitrate concentrations at three upland sites $(1,2$, and 3$)$ at depths as much as 100 feet below the land surface. The presence of nitrate in ground water is related to ground-water flow direction and land-use patterns in the area. Nitrate concentrations ranged from $5 \mathrm{mg} / \mathrm{L}$ in the northern part of the study area to $15 \mathrm{mg} / \mathrm{L}$ in the southern part. Most of the large nitrate concentrations were found in areas of irrigated farmland, particularly in lowland areas.

Difference in nitrate concentration with depth was measured at two sites in the irrigated lowland area. Data indicate that the aquifer is not well mixed vertically. Nitrate concentrations are largest at the top of the saturated zone and decrease with depth; therefore, the fully penetrating, fully screened wells yield samples most representative of the entire saturated thickness of the aquifer.

Because of very slow ground-water movement and the time lag between the implementation of the management plan and water-quality improvement, significant changes in concentrations of nitrate in ground water were not detected during the study period ( 3 years). To identify changes in concentrations of nitrate in the ground water, long-term repetitive sampling over the spatial network is necessary. Such changes will be detected most quickly in the shallow ground water beneath the lowland area.

Two sites were chosen for sediment coring during 3 consecutive years (1991-93) prior to fertilizer application in the spring to estimate the nitrate and ammonium, organic matter, and silt-clay content of the unsaturated zone. Both nitrate and ammonium forms of inorganic nitrogen were found throughout the entire sediment profile in the unsaturated zone. Maximum concentrations of nitrate were detected at or within 13 feet of the land surface at both sites, suggesting that the major source of nitrogen at these sites is from the land surface. Correlation analysis indicated that nitrate, organic matter, and silt-clay content decreased with depth, whereas ammonium increased with depth at site 1. At site 9, ammonium concentrations and organic matter decreased with depth, whereas the nitrate and silt-clay content appeared to be independent of sampling depth. Nitrate plus ammonium as nitrogen loads were estimated as $1,166,877$, and $1,166 \mathrm{lb} / \mathrm{acre}$ at site 1 and 444,228 , and $271 \mathrm{lb} / \mathrm{acre}$ at site 9, for the 3-year period.

Bromide tracer experiments were conducted to estimate the annual rate of movement of nitrate in the unsaturated zone. Bromide tracer had leached to 9 and 13 feet below the land surface at sites 1 and 9, respectively. Thus, an annual rate of downward movement of nitrate was estimated to be about 11 feet. It may take about 2 years and more than 9 years for nitrate to reach ground water in the lowland and the upland, respectively. 


\section{SELECTED REFERENCES}

Aller, Linda, 1991, Handbook of suggested practices for the design and installation of ground-water monitoring wells: Dublin, Ohio, National Water Well Association, $398 \mathrm{p}$.

Aravena, R., Evans, M.L., and Cherry, J.A., 1993, Stable isotopes of oxygen and nitrogen in source identification of nitrate from septic systems: Ground Water, v. 31 , no. 2 , p. $180-86$.

Bohn, H.L., McNeal, B.L., and O'Connor, G.A., 1985, Soil chemistry (2d ed.): New York, John Wiley and Sons, $341 \mathrm{p}$.

Burchett, R.R., Dreeszen, V.H., Reed, E.C., and Prichard, G.E., 1972, Bedrock geologic map showing thickness of overlying Quaternary deposits, Lincoln quadrangle and part of Nebraska City quadrangle, Nebraska and Kansas: U.S. Geological Survey Miscellaneous Investigations Series Map I-729, scale 1:250,000.

Chen, H.H., and Druliner, A.D., 1987, Nonpoint-source agricultural chemicals in ground water in Nebraska-Preliminary results for six areas of the High Plains aquifer: U.S. Geological Survey WaterResources Investigations Report 86-4338, 68 p.

Conover, W.J., 1989, Practical nonparametric statistics: New York, John Wiley and Sons, 493 p.

Conservation and Survey Division, 1953, Logs of test holes, Nuckolls County, Nebraska: Lincoln, University of Nebraska, Conservation and Survey Division, Test Hole Report THR-48, 13 p.

Conservation and Survey Division, 1980, Configuration of base of principal aquifer, Nebraska, 1979: Lincoln, Nebraska, Conservation and Survey Division, Institute of Agriculture and Natural Resources, University of Nebraska, Groundwater Map 52, scale 1:250,000.

Crawford, C.G., Slack, J.R., and Hirsch, R.M., 1983, Nonparametric tests for trends in water-quality data using the statistical analysis system: U.S. Geological Survey Open-File Report 83-550, 102 p.

Dreeszen, V.H., Reed, E.C., Burchett, R.R., and Prichard, G.E., 1973, Bedrock geologic map showing thickness of overlying Quaternary deposits, Grand Island quadrangle, Nebraska and Kansas: U.S. Geological Survey Miscellaneous Investigations Series Map I-819, scale 1:250,000.

Dugan, J.T., 1984, Hydrologic characteristics of Nebraska soils: U.S. Geological Survey Water-Supply Paper 2222, 19 p.

Ehrman, Richard, 1989, A study of nonpoint-source ground-water contamination in southern Nuckolls County, Nebraska-Special Protection Area Report: Nebraska Department of Environmental Control (Quality), 54 p.
Ellis, M.J., 1981, Hydrogeologic reconnaissance of the Republican River Basin in Nebraska: U.S. Geological Survey Open-File Report 81-531, scale 1:500,000, 1 sheet.

Engberg, R.A., 1984, Appraisal of data for ground-water quality in Nebraska: U.S. Geological Survey WaterSupply Paper 2245, 54 p.

Fenneman, N.M., 1946, Physical divisions of the United States: Washington, D.C., U.S. Geological Survey special map, scale 1:7,000,000.

Fishman, M.J., and Friedman, L.C., (eds.), 1989, Methods for determination of inorganic substances in water and fluvial sediments: U.S. Geological Survey Techniques of Water-Resources Investigations, book 5, chap. A1, $545 \mathrm{p}$.

Follett, R.F., Kenney, D.R., and Cruse, R.M., (eds.), 1991, Managing nitrogen for ground-water quality and farm profitability: Madison, Wisconsin, Soil Science Society of America, $357 \mathrm{p}$.

Gormly, J.R., and Spalding, R.F., 1979, Sources and concentrations of nitrate-nitrogen in ground water of Central Platte Region, Nebraska: Ground Water, v. 7, no. 3, p. 291-301.

Harris, J., Loftis, J.C., and Montgomery, R.H., 1987, Statistical methods for characterizing ground-water quality: Ground Water, v. 25, no. 2, p. 185-93.

Hirsch, R.M., Slack, J.R., and Smith, R.A., 1982, Techniques of trend analysis for monthly water-quality data: U.S. Geological Survey Open-File Report $81-488,30 \mathrm{p}$.

Kleiner, B., and Graedel, T.E., 1980, Exploratory data analysis in the geophysical sciences: Reviews of Geophysics and Space Physics, v. 18, no. 3, p. 699-717.

Kolpin, D.W., and Burkart, M.R., 1991, Work plan for regional reconnaissance for selected herbicides and nitrate in ground water of the mid-continent United States, 1991: U.S. Geological Survey Open-File Report 91-59, 18 p.

Komor, S.C., and Anderson, H.W., Jr., 1993, Nitrogen isotopes as indicators of nitrate sources in Minnesota sand-plain aquifers: Ground Water, v. 31, no. 2, p. 260-70.

Lower Republican Natural Resources District and Little Blue Natural Resources District, 1990, Superior-Hardy Special Protection Area Action Plan, 120 p.

McBean, E.A., and Rovers, F.A., 1984, Alternatives for assessing significance of changes in concentration levels: Groundwater monitoring review, summer 1994, p. 39-41.

Miller, R.D., Van Horn, R., Dobrovolny, E., and Buck, L.P., 1964, Geology of Franklin, Webster, and Nuckolls Counties, Nebraska: U.S. Geological Survey Bulletin $1165,91 \mathrm{p}$. 
Montgomery, R.H., Loftis, J.C., and Harris, J., 1987, Statistical characteristics of ground-water quality monitoring: Ground Water, v. 25, no. 2, p. 176-84.

SAS Institute, Inc., 1990, SAS/STAT user's guide: Version 6, (4th ed.), Cary, North Carolina, v. 2.

Soil Conservation Service and University of Nebraska Cooperative Extension, 1994, 1993 field demonstrations of best management practices to protect groundwater quality: SCREC94/2, 104 p.

Spruill, T.B., 1990, Monitoring regional ground-water quality-Statistical considerations and description of monitoring network in Kansas: U.S. Geological Survey Water-Resources Investigations Report 90-4159, $41 \mathrm{p}$.

Tukey, J.W., 1977, Exploratory data analysis: Reading, Massachusetts, Addison-Wesley, 688 p.

U.S. Department of Commerce, Bureau of the Census, 1993, 1990 Census of population and housing:
Summary population and housing characteristics, Nebraska, 303 p.

U.S. Environmental Protection Agency, 1994, Drinkingwater regulations and health advisories: U.S. Environmental Protection Agency, Office of Water, 11 p.

University of Nebraska, 1989, Adjusting nitrogen fertilizer for corn based on nitrate levels in soil and irrigation water: Cooperative Extension Service, NebGuide 89-913, 4 p.

Waite, H.A., Reed, E.C., and Jones, D.S., Jr., 1944, Ground water in the Republican River Basin, Nebraska, part 1, Nuckolls, Webster, Franklin, and Harlan Counties: Lincoln, Nebraska, Conservation and Survey Division, Institute of Agriculture and Natural Resources, University of Nebraska-Lincoln, Water Resources Survey Water-Supply Paper 1. 


\section{ADDITIONAL WATER-QUALITY AND SEDIMENT DATA}


Table 11. Water-quality data for samples from 20 monitoring wells in the study area, Nuckolls County, Nebraska, 1991-93

[--, no data; ${ }^{\circ} \mathrm{C}$, degrees Celsius; $\mathrm{mg} / \mathrm{L}$, milligrams per liter; $\mu \mathrm{S} / \mathrm{cm}$, microsiemens per centimeter $]$

\begin{tabular}{|c|c|c|c|c|c|c|c|c|}
\hline $\begin{array}{c}\text { Well } \\
\text { number }\end{array}$ & Date & Time & $\begin{array}{l}\text { Depth to } \\
\text { water } \\
\text { (feet) }\end{array}$ & $\begin{array}{c}\text { Tempers- } \\
\text { ture } \\
\left({ }^{\circ} \mathrm{C}\right)\end{array}$ & $\begin{array}{c}\text { pH } \\
\text { (standard } \\
\text { units) }\end{array}$ & $\begin{array}{c}\text { Specific } \\
\text { conductance } \\
(\mu \mathrm{S} / \mathrm{cm} \text { at } \\
\left.25^{\circ} \mathrm{C}\right)\end{array}$ & $\begin{array}{l}\text { Dissolved } \\
\text { oxygen } \\
\text { (mg/L) }\end{array}$ & $\begin{array}{c}\text { Nitrate } \\
\text { as } \\
\text { nitrogen } \\
\text { (mg/L) }\end{array}$ \\
\hline 1 & $7-02-91$ & $20: 18$ & 123.00 & 17.1 & 7.3 & 805 & 6.6 & 5.9 \\
\hline 1 & $8-02-91$ & $11: 30$ & 121.60 & 16.8 & 7.4 & 908 & 5.9 & 5.0 \\
\hline 1 & $8-21-91$ & $12: 22$ & 122.00 & 14.1 & 7.5 & 906 & 6.6 & 6.4 \\
\hline 1 & $9-04-91$ & $16: 30$ & 122.56 & 13.1 & 6.4 & 915 & 6.4 & 6.0 \\
\hline 1 & $11-12-91$ & $12: 05$ & 122.05 & 13.0 & 7.4 & 938 & 6.7 & 5.8 \\
\hline 1 & $1-17-92$ & 9:30 & -- & 12.5 & 7.1 & 939 & 6.8 & 6.2 \\
\hline 1 & $3-17-92$ & $14: 00$ & 124.16 & 13.0 & 7.4 & 951 & 6.1 & 5.6 \\
\hline 1 & $5-19-92$ & 11:20 & 126.15 & 15.5 & 7.2 & 928 & 7.6 & 6.0 \\
\hline 1 & $7-09-92$ & $14: 00$ & 126.05 & 12.4 & 7.3 & 952 & 6.6 & 6.0 \\
\hline 1 & $9-16-92$ & 8:00 & 126.00 & 13.2 & 7.3 & 940 & 7.2 & 6.1 \\
\hline 1 & $11-19-92$ & $10: 10$ & 124.28 & 11.8 & 7.4 & 926 & 6.8 & 6.5 \\
\hline 1 & $1-26-93$ & $13: 44$ & 125.45 & 12.4 & 7.1 & 894 & 8.0 & 6.1 \\
\hline 1 & $3-24-93$ & $14: 05$ & 125.49 & 12.8 & 7.2 & 875 & 6.3 & 7.0 \\
\hline 1 & $5-19-93$ & $15: 55$ & 125.56 & 12.6 & 7.1 & 863 & 6.5 & 5.9 \\
\hline 1 & $7-13-93$ & $14: 05$ & 124.49 & 14.3 & 7.2 & 849 & 6.2 & 6.1 \\
\hline 1 & $9-07-93$ & $15: 00$ & 122.50 & 13.3 & 6.9 & 864 & 8.2 & 6.0 \\
\hline 2 & $7-02-91$ & $18: 47$ & 130.40 & 13.7 & 7.2 & 630 & 6.8 & 7.0 \\
\hline 2 & $8-06-91$ & $17: 50$ & 137.00 & 13.3 & 7.2 & 732 & 7.7 & 8.1 \\
\hline 2 & $8-21-91$ & $11: 23$ & 136.55 & 13.3 & 7.2 & 740 & 7.1 & 8.3 \\
\hline 2 & $9-04-91$ & $18: 15$ & 136.25 & 13.2 & 6.1 & 722 & 7.1 & 8.6 \\
\hline 2 & $11-12-91$ & $13: 30$ & 135.61 & 13.1 & 7.2 & 758 & 7.4 & 9.0 \\
\hline 2 & $1-17-92$ & $10: 20$ & - & 12.8 & 7.0 & 747 & 6.9 & 9.9 \\
\hline 2 & $3-17-92$ & $15: 08$ & 134.98 & 13.1 & 6.9 & 732 & 7.0 & 7.6 \\
\hline 2 & $5-19-92$ & $13: 29$ & 135.40 & 14.0 & 7.2 & 716 & 9.2 & 7.5 \\
\hline 2 & $7-09-92$ & $14: 53$ & 134.13 & 13.3 & 7.12 & 695 & 9.2 & 7.6 \\
\hline 2 & $9-15-92$ & $18: 20$ & 126.80 & 13.4 & 7.1 & 673 & 10.9 & 7.5 \\
\hline 2 & $11-19-92$ & $11: 00$ & 134.72 & 12.9 & 7.3 & 677 & 9.0 & 6.8 \\
\hline 2 & $1-26-93$ & $15: 18$ & 134.70 & 12.6 & 7.2 & 664 & 9.3 & 6.0 \\
\hline 2 & $3-24-93$ & $13: 40$ & 134.34 & 13.3 & 7.1 & 652 & 9.6 & 6.9 \\
\hline 2 & $5-19-93$ & $16: 39$ & 134.01 & 13.0 & 7.2 & 640 & 9.0 & 5.7 \\
\hline 2 & $7-13-93$ & $14: 47$ & 133.31 & 13.6 & 7.2 & 640 & 9.6 & 5.6 \\
\hline 2 & $9-08-93$ & $14: 00$ & 133.47 & 13.4 & 7.1 & 638 & 10.4 & 5.4 \\
\hline 3 & $7-10-91$ & $14: 51$ & 118.40 & 14.2 & 7.2 & 964 & 11.1 & 9.9 \\
\hline 3 & $8-02-91$ & $15: 20$ & 121.50 & 13.3 & 7.0 & 658 & 6.8 & 9.3 \\
\hline 3 & $8-21-91$ & $13: 08$ & 123.70 & 13.3 & 7.2 & 658 & 6.9 & 9.4 \\
\hline 3 & $9-05-91$ & $9: 16$ & 122.70 & 13.2 & 7.1 & 666 & 6.4 & 9.0 \\
\hline 3 & $11-12-91$ & $14: 20$ & 122.40 & 13.3 & 7.0 & 664 & 6.7 & 9.1 \\
\hline 3 & $1-17-92$ & $8: 50$ & - & 12.8 & 7.0 & 657 & 6.1 & 9.4 \\
\hline 3 & $3-17-92$ & $13: 33$ & 122.27 & 13.8 & 6.9 & 655 & 5.4 & 8.6 \\
\hline 3 & $5-20-92$ & $9: 11$ & 122.28 & 13.8 & 6.8 & 663 & 8.9 & 8.8 \\
\hline 3 & $7-09-92$ & $13: 17$ & 122.78 & 13.3 & 7.0 & 656 & 8.7 & 8.2 \\
\hline 3 & $9-15-92$ & $17: 30$ & 115.30 & 13.6 & 7.1 & 652 & 9.8 & 8.2 \\
\hline 3 & $11-19-92$ & $9: 25$ & 122.22 & 13.0 & 7.2 & 649 & 8.5 & 8.3 \\
\hline
\end{tabular}


Table 11. Water-quality data for samples from 20 monitoring wells in the study area, Nuckolls County, Nebraska, 1991-93-Continued

[--, no data; ${ }^{\circ} \mathrm{C}$, degrees Celsius; $\mathrm{mg} / \mathrm{L}$, milligrams per liter; $\mu \mathrm{S} / \mathrm{cm}$, microsiemens per centimeter]

\begin{tabular}{|c|c|c|c|c|c|c|c|c|}
\hline $\begin{array}{c}\text { Well } \\
\text { number }\end{array}$ & Date & Time & $\begin{array}{l}\text { Depth to } \\
\text { water } \\
\text { (feet) }\end{array}$ & $\begin{array}{l}\text { Tempera- } \\
\text { ture } \\
\left({ }^{\circ} \mathrm{C}\right)\end{array}$ & $\begin{array}{c}\text { pH } \\
\text { (standard } \\
\text { units) }\end{array}$ & $\begin{array}{c}\text { Speciflc } \\
\text { conductance } \\
(\mu \mathrm{S} / \mathrm{cm} \text { at } \\
\left.25^{\circ} \mathrm{C}\right)\end{array}$ & $\begin{array}{l}\text { Dlssolved } \\
\text { oxygen } \\
\text { (mg/L) }\end{array}$ & $\begin{array}{l}\text { Nitrate } \\
\text { as } \\
\text { nitrogen } \\
\text { (mg/l) }\end{array}$ \\
\hline $3^{T}$ & $1-26-93$ & - & - & - & - & -- & - & -- \\
\hline 3 & $3-24-93$ & $13: 03$ & 122.07 & 13.3 & 7.0 & 654 & 9.4 & 8.9 \\
\hline 3 & $5-19-93$ & $15: 21$ & 123.27 & 13.1 & 7.1 & 651 & 8.4 & 7.6 \\
\hline 3 & $7-13-93$ & $15: 15$ & 121.20 & 13.5 & 7.0 & 656 & 9.2 & 7.2 \\
\hline 3 & $9-07-93$ & $15: 50$ & 121.26 & 13.3 & 7.0 & 648 & 9.8 & 7.6 \\
\hline 4 & $7-10-91$ & $15: 41$ & 58.70 & 15.0 & 6.8 & 959 & 8.4 & 24 \\
\hline 4 & $8-02-91$ & $20: 10$ & 58.50 & 13.3 & 6.7 & 1,040 & 5.4 & 24 \\
\hline 4 & $8-21-91$ & $14: 43$ & 58.70 & 13.3 & 6.9 & 1,050 & 5.4 & 24 \\
\hline 4 & $9-05-91$ & $10: 10$ & 59.65 & 13.2 & 6.7 & 1,050 & 5.3 & 25 \\
\hline 4 & $11-12-91$ & $15: 07$ & 58.80 & 13.3 & 6.7 & 1,070 & 5.6 & 24 \\
\hline 4 & $1-17-92$ & $11: 00$ & - & 13.1 & 6.7 & 1,060 & 5.1 & 23 \\
\hline 4 & $3-17-92$ & $15: 50$ & 58.80 & 13.7 & 6.6 & 1,060 & 4.8 & 24 \\
\hline 4 & $5-20-92$ & 9:53 & 59.08 & 13.7 & 6.5 & 1,070 & 7.5 & 22 \\
\hline 4 & $7-09-92$ & $15: 33$ & 59.03 & 13.2 & 6.8 & 1,060 & 7.3 & 22 \\
\hline 4 & $9-15-92$ & $16: 00$ & 58.60 & 13.5 & 6.8 & 1,060 & 8.4 & 22 \\
\hline 4 & $11-19-92$ & $11: 43$ & 58.30 & 13.0 & 6.8 & 1,050 & 7.0 & 25 \\
\hline 4 & $1-26-93$ & $16: 43$ & 59.40 & 13.0 & 6.7 & 1,030 & 7.3 & 23 \\
\hline 4 & $3-24-93$ & $12: 23$ & 58.26 & 13.3 & 6.7 & 980 & 7.1 & 24 \\
\hline 4 & $5-19-93$ & $14: 40$ & 57.64 & 13.1 & 6.8 & 880 & 7.2 & 23 \\
\hline 4 & $7-14-93$ & $10: 37$ & 56.90 & 13.3 & 6.8 & 723 & 8.6 & 17 \\
\hline 4 & $9-08-93$ & $14: 30$ & 55.58 & 13.3 & 7.0 & 648 & 9.8 & -- \\
\hline 5 & $7-01-91$ & $15: 30$ & 14.00 & 13.7 & 6.9 & 950 & 3.1 & 13 \\
\hline 5 & $8-01-91$ & $10: 35$ & 19.20 & 12.2 & 7.3 & 1,010 & .1 & 12 \\
\hline 5 & $8-19-91$ & $14: 00$ & 18.70 & 12.5 & 7.0 & 984 & .3 & 11 \\
\hline 5 & $9-05-91$ & $11: 10$ & 18.60 & 12.3 & 7.0 & 966 & .3 & 9.9 \\
\hline 5 & $11-12-91$ & $16: 00$ & 17.00 & 12.8 & 7.0 & 991 & .3 & 11 \\
\hline 5 & $1-16-92$ & $14: 22$ & - & 12.9 & 6.9 & 1,020 & .1 & 13 \\
\hline 5 & $3-18-92$ & $15: 00$ & 14.39 & 13.2 & 6.9 & 1,060 & .04 & 15 \\
\hline 5 & $5-20-92$ & $11: 24$ & 13.98 & 13.2 & 6.8 & 1,050 & .1 & 13 \\
\hline 5 & $7-10-92$ & $8: 57$ & 13.82 & 12.6 & 6.6 & 1,040 & .1 & 13 \\
\hline 5 & $9-15-92$ & $14: 48$ & 13.00 & 12.8 & 7.0 & 929 & 0.2 & 8.0 \\
\hline 5 & $11-19-92$ & $12: 27$ & 11.59 & 12.6 & 7.0 & 918 & .2 & 8.5 \\
\hline 5 & $1-26-93$ & $11: 54$ & 11.50 & 12.7 & 6.9 & 947 & .1 & 9.8 \\
\hline 5 & $3-23-93$ & $11: 35$ & 8.03 & 12.8 & 7.0 & 936 & .2 & 10 \\
\hline 5 & $5-19-93$ & $15: 25$ & 10.63 & 12.4 & 7.0 & 996 & .1 & 12 \\
\hline 5 & $7-13-93$ & $13: 30$ & 7.76 & 12.3 & 7.0 & 1,010 & .2 & 13 \\
\hline 5 & $9-08-93$ & $13: 15$ & 8.45 & 12.2 & 7.0 & 956 & .4 & 11 \\
\hline 6 & $7-10-91$ & $16: 50$ & 35.35 & 14.1 & 7.2 & 592 & 13.0 & 10 \\
\hline 6 & $8-06-91$ & $16: 10$ & 35.30 & 15.2 & 7.2 & 582 & 6.1 & 6.9 \\
\hline 6 & $8-21-91$ & $15: 15$ & 35.29 & 14.4 & 7.3 & 1,070 & 5.3 & 7.1 \\
\hline 6 & $9-05-91$ & $12: 10$ & 35.47 & 12.9 & 7.2 & 1,090 & 4.9 & 6.9 \\
\hline 6 & $11-12-91$ & $16: 33$ & 35.43 & 12.9 & 7.1 & 1,140 & 5.2 & 6.5 \\
\hline 6 & $1-16-92$ & $14: 40$ & - & 12.5 & 7.3 & 1,150 & 5.2 & 7.0 \\
\hline
\end{tabular}


Table 11. Water-quality data for samples from 20 monitoring wells in the study area, Nuckolls County, Nebraska, 1991-93-Continued

$\left[-\right.$, no data; ${ }^{\circ} \mathrm{C}$, degrees Celsius; $\mathrm{mg} / \mathrm{L}$, milligrams per liter; $\mu \mathrm{S} / \mathrm{cm}$, microsiemens per centimeter $]$

\begin{tabular}{|c|c|c|c|c|c|c|c|c|}
\hline $\begin{array}{c}\text { Well } \\
\text { number }\end{array}$ & Date & Time & $\begin{array}{l}\text { Depth to } \\
\text { water } \\
\text { (feet) }\end{array}$ & $\begin{array}{l}\text { Tempera- } \\
\text { ture } \\
\left({ }^{\circ} \mathrm{C}\right)\end{array}$ & $\begin{array}{c}\mathrm{pH} \\
\text { (standard } \\
\text { unlts) }\end{array}$ & $\begin{array}{c}\text { Specific } \\
\text { conductance } \\
\text { ( } \mu \text { S/cm at } \\
25^{\circ} \mathrm{C} \text { ) }\end{array}$ & $\begin{array}{l}\text { Dissolved } \\
\text { oxygen } \\
\text { (mg/L) }\end{array}$ & $\begin{array}{c}\text { Nitrate } \\
\text { as } \\
\text { nitrogen } \\
\text { (mg/L) }\end{array}$ \\
\hline 6 & $3-17-92$ & $16: 30$ & 35.88 & 12.4 & 7.2 & 1,150 & 3.8 & 6.5 \\
\hline 6 & $5-20-92$ & $14: 12$ & 35.36 & 13.5 & 7.2 & 1,170 & 7.1 & 6.6 \\
\hline 6 & $7-10-92$ & $9: 30$ & 33.19 & 13.4 & 7.1 & 1,170 & 6.2 & 6.9 \\
\hline 6 & $9-15-92$ & $15: 26$ & 35.10 & 15.5 & 7.4 & 1,050 & 7.1 & 6.9 \\
\hline 6 & $11-19-92$ & $14: 55$ & 36.80 & 11.8 & 7.3 & 1,020 & 6.2 & 8.3 \\
\hline 6 & $1-26-93$ & $12: 25$ & 34.40 & 12.5 & 7.0 & 1,130 & 7.9 & 14 \\
\hline 6 & $3-23-93$ & $12: 35$ & 33.94 & 13.4 & 7.1 & 1,130 & 7.5 & -- \\
\hline 6 & $5-19-93$ & $13: 55$ & 34.61 & 12.8 & 7.0 & 1,060 & 7.1 & 18 \\
\hline 6 & $7-14-93$ & 11:08 & 32.50 & 14.0 & 7.0 & 498 & 8.1 & 17 \\
\hline 6 & $9-07-93$ & $13: 50$ & 31.52 & 12.9 & 6.9 & 1,180 & - & -- \\
\hline 7 & $7-01-91$ & $17: 50$ & 26.45 & 12.9 & 6.7 & 800 & 2.4 & 7.2 \\
\hline 7 & $8-02-91$ & $18: 50$ & 26.65 & 12.7 & 6.8 & 832 & 2.8 & 6.5 \\
\hline 7 & $8-21-91$ & $15: 45$ & 25.25 & 12.6 & 7.0 & 823 & 3.0 & 6.6 \\
\hline 7 & $9-05-91$ & $13: 00$ & 25.02 & 12.5 & 6.8 & 832 & 2.6 & 6.3 \\
\hline 7 & $11-12-91$ & $17: 18$ & 25.68 & 12.6 & 6.8 & 844 & 2.3 & 5.2 \\
\hline 7 & $1-16-92$ & $15: 25$ & -- & 12.5 & 6.7 & 827 & 2.3 & 6.4 \\
\hline 7 & $3-18-92$ & $14: 15$ & 25.04 & 13.1 & 6.7 & 828 & 3.2 & 5.9 \\
\hline 7 & $5-19-92$ & $17: 27$ & 25.06 & 13.4 & 6.6 & 834 & 3.2 & 6.0 \\
\hline 7 & $7-10-92$ & $8: 15$ & 25.44 & 12.7 & 6.5 & 814 & 3.5 & 6.1 \\
\hline 7 & $9-15-92$ & $13: 39$ & 22.90 & 12.8 & 6.9 & 799 & 4.1 & 6.1 \\
\hline 7 & $11-19-92$ & $15: 55$ & 23.02 & 12.5 & 6.9 & 812 & 2.8 & 6.0 \\
\hline 7 & $1-27-93$ & $10: 15$ & 22.70 & 12.5 & 6.7 & 820 & 2.6 & 6.0 \\
\hline 7 & $3-24-93$ & $11: 19$ & 20.87 & 12.9 & 6.8 & 829 & 2.4 & 6.0 \\
\hline 7 & $5-19-93$ & $12: 45$ & 21.62 & 12.7 & 6.8 & 853 & 2.4 & 6.2 \\
\hline 7 & $7-14-93$ & $11: 50$ & 18.22 & 12.7 & 6.8 & 892 & 2.8 & 7.4 \\
\hline 7 & $9-08-93$ & $12: 05$ & 18.72 & 12.4 & 6.8 & 914 & 3.3 & 8.5 \\
\hline 8 & $7-10-91$ & $21: 35$ & 8.15 & 13.3 & 7.1 & 709 & 10 & 4.6 \\
\hline 8 & $8-02-91$ & $13: 10$ & 9.55 & 13.3 & 6.9 & 1,300 & 4.9 & 4.0 \\
\hline 8 & $8-21-91$ & $16: 18$ & 9.83 & 13.8 & 6.8 & 1,340 & 4.4 & 5.8 \\
\hline 8 & $9-05-91$ & $14: 30$ & 9.90 & 13.3 & 6.8 & 1,320 & 3.4 & 5.3 \\
\hline 8 & $11-13-91$ & $9: 20$ & 11.10 & 13.4 & 6.2 & 1,260 & 2.6 & 3.2 \\
\hline 8 & $1-16-92$ & $11: 30$ & - & 12.6 & 6.7 & 1,160 & 3.1 & 2.2 \\
\hline 8 & $3-17-92$ & $12: 30$ & 12.09 & 11.6 & 7.1 & 1,150 & 2.2 & 2.2 \\
\hline 8 & $5-20-92$ & $16: 58$ & 12.70 & 13.8 & 7.0 & 1,140 & 5.1 & 2.4 \\
\hline 8 & $7-09-92$ & $12: 00$ & 10.94 & 12.3 & 6.91 & 595 & 5.0 & 3.4 \\
\hline 8 & $9-15-92$ & $12: 30$ & 7.90 & 14.6 & 7.0 & 1,300 & 5.0 & 6.1 \\
\hline 8 & $11-18-92$ & $16: 57$ & 6.87 & 12.9 & 6.9 & 1,350 & 5.0 & 4.3 \\
\hline 8 & $1-26-93$ & $10: 30$ & 6.80 & 10.0 & 7.2 & 1,330 & - & 2.5 \\
\hline 8 & $3-24-93$ & $14: 58$ & 2.38 & 8.0 & 7.1 & 1,300 & 5.8 & 1.7 \\
\hline 8 & $5-19-93$ & $11: 45$ & 3.86 & 9.3 & 6.8 & 1,280 & 3.5 & 1.0 \\
\hline 8 & $7-12-93$ & $18: 28$ & 3.33 & 13.0 & 7.2 & 1,190 & 4.2 & 1.1 \\
\hline 8 & $9-07-93$ & $14: 20$ & 2.66 & 13.8 & 7.0 & 1,140 & 3.3 & 1.3 \\
\hline
\end{tabular}


Table 11. Water-quality data for samples from 20 monitoring wells in the study area, Nuckolls County, Nebraska, 1991-93-Continued

$\left[-\right.$, no data; ${ }^{\circ} \mathrm{C}$, degrees Celsius; $\mathrm{mg} / \mathrm{L}$, milligrams per liter; $\mu \mathrm{S} / \mathrm{cm}$, microsiemens per centimeter $]$

\begin{tabular}{|c|c|c|c|c|c|c|c|c|}
\hline $\begin{array}{c}\text { Well } \\
\text { number }\end{array}$ & Date & Time & $\begin{array}{l}\text { Depth to } \\
\text { water } \\
\text { (feet) }\end{array}$ & $\begin{array}{c}\text { Tempera- } \\
\text { fure } \\
\left({ }^{\circ} \mathrm{C}\right)\end{array}$ & $\begin{array}{c}\text { pH } \\
\text { (standard } \\
\text { units) }\end{array}$ & $\begin{array}{c}\text { Speclific } \\
\text { conductance } \\
(\mu \mathrm{S} / \mathrm{cm} \text { at } \\
\left.25^{\circ} \mathrm{C}\right)\end{array}$ & $\begin{array}{l}\text { Dissoived } \\
\text { oxygen } \\
\text { (mg/L) }\end{array}$ & $\begin{array}{l}\text { Nitrate } \\
\text { as } \\
\text { nitrogen } \\
\text { (mg/L) }\end{array}$ \\
\hline $9 A$ & $7-10-91$ & $20: 46$ & 13.50 & 13.9 & 7.3 & 811 & 9.4 & 11 \\
\hline $9 \mathrm{~A}$ & 8-01-91 & $12: 00$ & 12.90 & 13.0 & 7.3 & 795 & .8 & 8.8 \\
\hline $9 A$ & $8-20-91$ & $20: 32$ & 13.00 & 13.0 & 7.1 & 850 & 1.3 & 12 \\
\hline $9 A$ & $9-05-91$ & $15: 30$ & 13.60 & 13.5 & 7.0 & 807 & 1.1 & 10 \\
\hline $9 \mathrm{~A}$ & $11-13-91$ & $8: 14$ & 15.18 & 13.3 & 6.8 & 842 & 1.4 & 11 \\
\hline $9 A$ & $1-16-92$ & $12: 35$ & -- & 13.4 & 7.0 & 846 & 1.4 & 13 \\
\hline $9 A$ & $3-17-92$ & $11: 23$ & 15.63 & 13.8 & 6.8 & 861 & 2.2 & 12 \\
\hline $9 \mathrm{~A}$ & $5-19-92$ & $15: 55$ & 15.79 & 13.7 & 6.7 & 901 & 2.3 & 13 \\
\hline $9 \mathrm{~A}$ & $7-09-92$ & $10: 45$ & 15.83 & 13.1 & 6.8 & 953 & 2.3 & 15 \\
\hline $9 A$ & $9-15-92$ & $11: 20$ & 12.70 & 13.1 & 7.1 & 905 & 2.3 & 14 \\
\hline $9 A$ & $11-18-92$ & $15: 57$ & 13.78 & 12.9 & 6.8 & 913 & 2.5 & 15 \\
\hline $9 A^{\prime}$ & $1-26-93$ & - & - & -- & -- & -- & -- & -- \\
\hline $9 A$ & $3-24-93$ & 9:58 & 13.13 & 12.8 & 6.9 & 913 & 2.4 & 14 \\
\hline $9 A$ & $5-18-93$ & $14: 47$ & 12.27 & 12.8 & 7.1 & 891 & 2.2 & 13 \\
\hline $9 A$ & $7-12-93$ & $17: 15$ & 10.93 & 12.9 & 7.2 & 841 & 1.8 & 12 \\
\hline 9B & $7-10-91$ & $20: 27$ & - & 14.0 & 7.0 & 486 & 2.5 & 9.3 \\
\hline 9B & $8-01-91$ & $12: 20$ & - & 13.1 & 7.3 & 748 & .5 & 7.1 \\
\hline 9B & $8-20-91$ & $20: 07$ & -- & 13.1 & 7.1 & 737 & .7 & 7.5 \\
\hline 9B & 9-05-91 & $15: 50$ & -- & 13.2 & 7.0 & 715 & 1.9 & 5.6 \\
\hline $9 B$ & $11-13-91$ & $8: 30$ & -- & 13.3 & 6. & 762 & 2.2 & 7.4 \\
\hline 9B & $1-16-92$ & $12: 50$ & - & 13.2 & 6.8 & 813 & 2.5 & 10 \\
\hline $9 B$ & $3-17-92$ & $11: 45$ & - & 13.8 & 6.9 & 807 & 3.2 & 8.8 \\
\hline 9B & $5-19-92$ & $16: 19$ & - & 14.2 & 6.7 & 856 & 3.8 & 9.9 \\
\hline 9B & $7-09-92$ & $11: 05$ & -- & 13.4 & 6.9 & 947 & 4.5 & 14 \\
\hline 9B & $9-15-92$ & $11: 42$ & -- & 13.4 & 7.1 & 842 & 5.8 & 11 \\
\hline 9B & $11-18-92$ & $16: 13$ & -- & 13.0 & 6.8 & 859 & 3.6 & 12 \\
\hline $9 B^{1}$ & $1-26-93$ & - & -- & -- & -- & -- & -- & -- \\
\hline 9B & $3-24-93$ & $10: 16$ & -- & 13.0 & 6.9 & 846 & 2.3 & 9.5 \\
\hline 9B & $5-18-93$ & $15: 05$ & -- & 13.0 & 7.1 & 821 & 2.5 & 9.6 \\
\hline 9B & $7-12-93$ & $17: 35$ & - & 13.2 & 7.1 & 730 & .7 & 6.3 \\
\hline $9 B$ & $9-08-93$ & $12: 25$ & -- & 12.8 & 6.9 & 808 & 2.9 & 12 \\
\hline $9 \mathrm{C}$ & $7-10-91$ & $20: 29$ & -- & 13.6 & 7.0 & 505 & 3.6 & 26 \\
\hline $9 \mathrm{C}$ & $8-01-91$ & $12: 40$ & -- & 12.9 & 7.3 & 1,120 & 2.4 & 26 \\
\hline $9 \mathrm{C}$ & $8-20-91$ & $19: 51$ & - & 13.1 & 7.3 & 1,130 & 2.3 & 25 \\
\hline $9 \mathrm{C}$ & $9-05-91$ & $16: 10$ & -- & 13.2 & 7.1 & 1,160 & 2.5 & 29 \\
\hline $9 \mathrm{C}$ & $11-13-91$ & $8: 44$ & -- & 13.9 & 6.7 & 1,210 & 2.2 & 26 \\
\hline $9 \mathrm{C}$ & $1-16-92$ & $13: 15$ & -- & 13.9 & 7.1 & 1,140 & 1.8 & 25 \\
\hline $9 \mathrm{C}$ & $3-17-92$ & $12: 05$ & - & 13.8 & 7.1 & 1,110 & 2.2 & 25 \\
\hline $9 \mathrm{C}$ & $5-19-92$ & $16: 40$ & -- & 13.3 & 6.9 & 1,170 & 3.0 & 26 \\
\hline $9 \mathrm{C}$ & $7-09-92$ & $11: 25$ & -- & 12.7 & 7.2 & 1,120 & 2.9 & 25 \\
\hline $9 \mathrm{C}$ & $9-15-92$ & $12: 01$ & -- & 13.2 & 7.1 & 1,150 & 3.2 & 28 \\
\hline $9 \mathrm{C}$ & $11-18-92$ & $16: 30$ & -- & 13.3 & 7.0 & 1,120 & 2.6 & 28 \\
\hline $9 C^{1}$ & $1-26-93$ & -- & -- & -- & - & - & - & - \\
\hline
\end{tabular}


Table 11. Water-quality data for samples from 20 monitoring wells in the study area, Nuckolls County, Nebraska, 1991-93-Continued

[--, no data; ${ }^{\circ} \mathrm{C}$, degrees Celsius; $\mathrm{mg} / \mathrm{L}$, milligrams per liter; $\mu \mathrm{S} / \mathrm{cm}$, microsiemens per centimeter $]$

\begin{tabular}{|c|c|c|c|c|c|c|c|c|}
\hline $\begin{array}{c}\text { Well } \\
\text { number }\end{array}$ & Date & Time & $\begin{array}{l}\text { Depth to } \\
\text { water } \\
\text { (feet) }\end{array}$ & $\begin{array}{l}\text { Tempera- } \\
\text { ture } \\
\left({ }^{\circ} \mathrm{C}\right)\end{array}$ & $\begin{array}{c}\text { pH } \\
\text { (standard } \\
\text { units) }\end{array}$ & $\begin{array}{c}\text { Specific } \\
\text { conductance } \\
(\mu \mathrm{S} / \mathrm{cm} \text { at } \\
\left.25^{\circ} \mathrm{C}\right)\end{array}$ & $\begin{array}{l}\text { Dlssolved } \\
\text { oxygen } \\
\text { (mg/L) }\end{array}$ & $\begin{array}{c}\text { Nitrate } \\
\text { as } \\
\text { nitrogen } \\
\text { (mg/L) }\end{array}$ \\
\hline $9 \mathrm{C}$ & $3-24-93$ & $10: 35$ & -- & 12.7 & 7.0 & 1,120 & 3.1 & 24 \\
\hline $9 \mathrm{C}$ & $5-18-93$ & $15: 23$ & - & 12.3 & 7.3 & 1,180 & 3.8 & 28 \\
\hline $9 \mathrm{C}$ & $7-12-93$ & $17: 55$ & - & 12.4 & 7.2 & 1,180 & 3.8 & 28 \\
\hline $9 \mathrm{C}$ & $9-07-93$ & $12: 45$ & -- & 12.5 & 7.1 & 1,200 & 3.9 & 31 \\
\hline 10 & $7-01-91$ & $19: 27$ & 16.00 & 12.5 & 7.0 & 800 & 3.6 & 11 \\
\hline 10 & $8-01-91$ & $9: 20$ & 16.20 & 12.4 & 7.3 & 872 & 3.2 & 9.5 \\
\hline 10 & $8-20-91$ & $16: 20$ & 16.30 & 12.4 & 7.1 & 850 & 2.8 & 9.9 \\
\hline 10 & $9-05-91$ & $17: 50$ & 16.30 & 12.5 & 7.1 & 828 & 2.6 & 9.2 \\
\hline 10 & $11-13-91$ & $10: 35$ & 16.23 & 12.9 & 7.0 & 824 & 1.9 & 8.1 \\
\hline 10 & $1-16-92$ & $16: 30$ & -- & 13.0 & 6.9 & 803 & 1.6 & 9.4 \\
\hline 10 & $3-17-92$ & $17: 15$ & 15.55 & 13.6 & 6.6 & 797 & .9 & 9.7 \\
\hline 10 & $5-20-92$ & $12: 08$ & 16.04 & 13.4 & 6.7 & 798 & 1.2 & 10 \\
\hline 10 & $7-10-92$ & $14: 49$ & 16.47 & 12.7 & 6.8 & 776 & .8 & 10 \\
\hline 10 & $9-16-92$ & $12: 10$ & 14.60 & 12.7 & 6.8 & 754 & .7 & 10 \\
\hline 10 & $11-20-92$ & $13: 30$ & 13.25 & 12.8 & 6.7 & 751 & 1.8 & 11 \\
\hline 10 & $1-27-93$ & $12: 15$ & 15.00 & 13.1 & 6.7 & 770 & 1.2 & 11 \\
\hline 10 & $3-24-93$ & $9: 15$ & 14.73 & 13.0 & 6.8 & 769 & 2.7 & 11 \\
\hline 10 & $5-19-93$ & $11: 15$ & 15.73 & 12.6 & 6.8 & 751 & 2.4 & 10 \\
\hline 10 & $7-13-93$ & $17: 07$ & 13.41 & 12.4 & 6.8 & 684 & 2.6 & 10 \\
\hline 10 & 9-07-93 & $16: 35$ & 11.81 & 12.2 & 6.8 & 740 & 2.4 & 10 \\
\hline 11 & $7-10-91$ & $12: 23$ & 12.00 & 13.9 & 7.1 & 878 & 8.3 & 18 \\
\hline 11 & $8-01-91$ & $8: 15$ & 12.00 & 13.0 & 7.3 & 914 & 5.4 & 19 \\
\hline 11 & $8-20-91$ & $14: 30$ & 12.00 & 13.5 & 7.0 & 911 & 5.3 & 20 \\
\hline 11 & $9-05-91$ & $19: 00$ & 12.10 & 13.7 & 7.2 & 913 & 5.2 & 19 \\
\hline 11 & $11-13-91$ & $11: 10$ & 12.04 & 14.0 & 7.0 & 904 & 4.8 & 17 \\
\hline 11 & $1-16-92$ & $17: 10$ & - & 12.8 & 6.9 & 880 & 4.8 & 18 \\
\hline 11 & $3-17-92$ & $18: 00$ & 11.88 & 12.4 & 6.8 & 880 & 2.8 & 16 \\
\hline 11 & $5-20-92$ & $12: 51$ & 12.08 & 12.8 & 6.9 & 896 & 6.5 & 18 \\
\hline 11 & $7-10-92$ & $13: 07$ & 12.08 & 12.9 & 6.9 & 886 & 6.7 & 18 \\
\hline 11 & $9-16-92$ & $12: 49$ & 11.40 & 14.0 & 6.9 & 877 & 6.6 & 18 \\
\hline 11 & $11-20-92$ & $12: 45$ & 11.20 & 13.6 & 6.9 & 875 & 6.8 & 19 \\
\hline 11 & $1-26-93$ & $9: 23$ & 12.00 & 12.4 & 6.9 & 866 & 7.2 & 17 \\
\hline 11 & $3-24-93$ & $8: 28$ & 11.66 & 11.7 & 7.0 & 853 & 7.2 & 18 \\
\hline 11 & $5-19-93$ & $10: 33$ & 13.30 & 11.8 & 7.0 & 856 & 6.5 & 15 \\
\hline 11 & $7-13-93$ & $14: 22$ & 7.92 & 13.2 & 7.0 & 858 & 6.6 & 16 \\
\hline 11 & $9-07-93$ & $17: 10$ & 9.51 & 12.8 & 6.9 & 853 & 6.5 & 16 \\
\hline 12 & $7-09-91$ & $15: 25$ & 42.50 & 13.6 & 6.6 & 308 & 7.5 & 4.5 \\
\hline 12 & $8-02-91$ & $18: 05$ & 43.40 & 12.7 & 6.8 & 749 & 4.7 & 4.5 \\
\hline 12 & $8-21-91$ & $17: 48$ & 43.75 & 12.9 & 7.1 & 763 & 4.3 & 5.1 \\
\hline 12 & $9-06-91$ & $10: 30$ & 44.55 & 12.7 & 7.0 & 797 & 4.4 & 4.7 \\
\hline 12 & $11-13-91$ & $12: 40$ & 45.15 & 12.7 & 6.8 & 822 & 4.1 & 4.7 \\
\hline 12 & $1-17-92$ & $12: 30$ & -- & 12.5 & 6.7 & 750 & 4.3 & 5.2 \\
\hline
\end{tabular}


Tabie 11. Water-quality data for samples from 20 monitoring wells in the study area, Nuckolls County, Nebraska, 1991-93 - Continued

$\left[-\right.$, no data; ${ }^{\circ} \mathrm{C}$, degrees Celsius; $\mathrm{mg} / \mathrm{L}$, milligrams per liter; $\mu \mathrm{S} / \mathrm{cm}$, microsiemens per centimeter $]$

\begin{tabular}{|c|c|c|c|c|c|c|c|c|}
\hline $\begin{array}{c}\text { Well } \\
\text { number }\end{array}$ & Date & Time & $\begin{array}{l}\text { Depth to } \\
\text { water } \\
\text { (feet) }\end{array}$ & $\begin{array}{c}\text { Tempera- } \\
\text { ture } \\
\left({ }^{\circ} \mathrm{C}\right)\end{array}$ & $\begin{array}{c}\text { pH } \\
\text { (standard } \\
\text { unlts) }\end{array}$ & $\begin{array}{c}\text { Speciflc } \\
\text { conductance } \\
(\mu \mathrm{S} / \mathrm{cm} \text { at } \\
\left.25^{\circ} \mathrm{C}\right)\end{array}$ & $\begin{array}{l}\text { Dissolved } \\
\text { oxygen } \\
\text { (mg/L) }\end{array}$ & $\begin{array}{c}\text { Nitrate } \\
\text { as } \\
\text { nitrogen } \\
\text { (mg/L) }\end{array}$ \\
\hline 12 & $3-18-92$ & $10: 10$ & 45.27 & 13.2 & 6.8 & 684 & 7.6 & 7.4 \\
\hline 12 & $5-20-92$ & $16: 22$ & 45.80 & 13.3 & 6.6 & 656 & 7.2 & 9.3 \\
\hline 12 & $7-09-92$ & $17: 50$ & 46.65 & 12.9 & 6.8 & 698 & 6.7 & 6.4 \\
\hline 12 & $9-16-92$ & $15: 15$ & 46.10 & 13.0 & 6.7 & 769 & 6.1 & 4.7 \\
\hline 12 & $11-20-92$ & $9: 45$ & 45.75 & 12.5 & 6.7 & 813 & 5.2 & 4.3 \\
\hline 12 & $1-25-93$ & $15: 05$ & 46.30 & 12.6 & 6.8 & 834 & 4.7 & 3.9 \\
\hline 12 & $3-23-93$ & $15: 48$ & 43.90 & 12.7 & 6.8 & 838 & 5.0 & 4.2 \\
\hline 12 & $5-18-93$ & $18: 13$ & 44.28 & 12.7 & 6.9 & 861 & 5.8 & 6.2 \\
\hline 12 & $7-14-93$ & $9: 40$ & 42.02 & 12.9 & 6.9 & 888 & 8.1 & 8.9 \\
\hline 12 & $9-08-93$ & $8: 10$ & 41.07 & 12.5 & 6.7 & 883 & 6.5 & 9.1 \\
\hline $13 \mathrm{~A}$ & $7-02-91$ & 08:10 & 24.00 & 12.6 & 7.1 & 710 & 5.3 & 10 \\
\hline $13 \mathrm{~A}$ & $7-31-91$ & $17: 56$ & 22.80 & 12.3 & 7.4 & 791 & 5.4 & 8.6 \\
\hline $13 \mathrm{~A}$ & $8-19-91$ & $18: 23$ & 22.42 & 12.5 & 7.1 & 790 & 5.5 & 11 \\
\hline $13 \mathrm{~A}$ & $9-06-91$ & 09:10 & 22.50 & 12.3 & 7.3 & 795 & 5.2 & 10 \\
\hline $13 \mathrm{~A}$ & $11-13-91$ & $11: 40$ & 23.58 & 12.6 & 7.1 & 776 & 4.6 & 10 \\
\hline $13 \mathrm{~A}$ & $1-17-92$ & $11: 35$ & -- & 12.5 & 7.1 & 791 & 4.6 & 11 \\
\hline $13 \mathrm{~A}$ & $3-18-92$ & $12: 50$ & 24.29 & 13.2 & 7.0 & 787 & 6.3 & 9.6 \\
\hline $13 \mathrm{~A}$ & $5-19-92$ & $19: 05$ & 24.50 & 13.2 & 6.8 & 801 & 6.4 & 10 \\
\hline $13 \mathrm{~A}$ & $7-09-92$ & $16: 35$ & 25.75 & 12.7 & 7.2 & 807 & 6.7 & 11 \\
\hline $13 \mathrm{~A}$ & $9-16-92$ & $13: 27$ & 21.90 & 12.7 & 7.1 & 784 & 6.5 & 10 \\
\hline $13 \mathrm{~A}$ & $11-19-92$ & $16: 35$ & 22.55 & 12.5 & 7.1 & 764 & 6.1 & 10 \\
\hline $13 \mathrm{~A}$ & $1-25-93$ & $13: 51$ & 23.30 & 12.6 & 6.9 & 795 & 6.3 & 11 \\
\hline $13 \mathrm{~A}$ & $3-23-93$ & $13: 37$ & 22.26 & 12.8 & 7.1 & 809 & 6.7 & 13 \\
\hline $13 \mathrm{~A}$ & $5-18-93$ & $16: 05$ & 21.39 & 12.7 & 7.2 & 801 & 6.7 & 11 \\
\hline $13 \mathrm{~A}$ & $7-13-93$ & $11: 10$ & 20.97 & 12.7 & 7.2 & 799 & 6.4 & 11 \\
\hline $13 \mathrm{~A}$ & $9-08-93$ & $10: 45$ & 16.35 & 12.4 & 7.1 & 767 & 6.5 & 9.4 \\
\hline $13 B$ & $7-02-91$ & $12: 08$ & -- & 12.8 & 7.1 & 700 & 5.0 & 9.5 \\
\hline $13 B$ & $7-31-91$ & $18: 20$ & -- & 12.3 & 7.4 & 775 & 5.1 & 10 \\
\hline $13 B$ & $8-19-91$ & $18: 35$ & -- & 12.5 & 7.1 & 769 & 5.1 & 10 \\
\hline $13 \mathrm{~B}$ & $9-06-91$ & 09:26 & - & 12.4 & 7.3 & 770 & 4.8 & 9.6 \\
\hline $13 B$ & $11-13-91$ & 11:55 & -- & 12.6 & 7.1 & 782 & 4.2 & 9.2 \\
\hline $13 B$ & $1-17-92$ & $11: 55$ & -- & 12.5 & 7.1 & 773 & 4.3 & 9.8 \\
\hline $13 B$ & $3-18-92$ & $13: 08$ & - & 13.1 & 7.1 & 774 & 6.0 & 8.9 \\
\hline $13 B$ & 5-19-92 & $19: 23$ & -- & 13.2 & 6.9 & 790 & 5.8 & 9.7 \\
\hline $13 B$ & $7-09-92$ & $16: 53$ & -- & 12.8 & 7.2 & 785 & 6.2 & 10 \\
\hline $13 B$ & $9-16-92$ & $13: 43$ & - & 12.9 & 7.1 & 766 & 6.0 & 9.3 \\
\hline $13 B$ & $11-19-92$ & $16: 52$ & -- & 12.4 & 7.2 & 760 & 5.8 & 9.6 \\
\hline $13 B$ & $1-25-93$ & $14: 09$ & - & 12.5 & 7.0 & 773 & 5.7 & 10 \\
\hline $13 B$ & $3-23-93$ & $14: 00$ & -- & 12.8 & 7.1 & 790 & 6.3 & 12 \\
\hline $13 B$ & $5-18-93$ & $16: 23$ & - & 12.8 & 7.3 & 787 & 6.3 & 10 \\
\hline $13 B$ & $7-13-93$ & $11: 27$ & - & 13.0 & 7.8 & 782 & 5.9 & 10 \\
\hline $13 B$ & $9-08-93$ & 11:05 & -- & 12.5 & 7.1 & 746 & 6.0 & 8.9 \\
\hline
\end{tabular}


Table 11. Water-quality data for samples from 20 monitoring wells in the study area, Nuckolls County, Nebraska, 1991-93-Continued

$\left[--\right.$, no data; ${ }^{\circ} \mathrm{C}$, degrees Celsius; $\mathrm{mg} / \mathrm{L}$, milligrams per liter; $\mu \mathrm{S} / \mathrm{cm}$, microsiemens per centimeter $]$

\begin{tabular}{|c|c|c|c|c|c|c|c|c|}
\hline $\begin{array}{c}\text { Well } \\
\text { number }\end{array}$ & Date & Time & $\begin{array}{l}\text { Depth to } \\
\text { water } \\
\text { (feet) }\end{array}$ & $\begin{array}{l}\text { Tempera- } \\
\text { ture } \\
\left({ }^{\circ} \mathrm{C}\right)\end{array}$ & $\begin{array}{c}\text { pH } \\
\text { (standard } \\
\text { unlts) }\end{array}$ & $\begin{array}{c}\text { Specific } \\
\text { conductance } \\
(\mu \mathrm{S} / \mathrm{cm} \text { at } \\
\left.25^{\circ} \mathrm{C}\right)\end{array}$ & $\begin{array}{c}\text { Dissolved } \\
\text { oxygen } \\
\text { (mg/L) }\end{array}$ & $\begin{array}{l}\text { Nitrate } \\
\text { as } \\
\text { nltrogen } \\
\text { (mg/L) }\end{array}$ \\
\hline $13 \mathrm{C}$ & $7-02-91$ & $12: 37$ & - & 12.6 & 7.2 & 740 & 5.6 & 12 \\
\hline $13 \mathrm{C}$ & $7-31-91$ & $18: 45$ & - & 12.4 & 7.3 & 808 & 5.6 & 10 \\
\hline $13 C$ & $8-19-91$ & $18: 51$ & - & 12.3 & 7.2 & 836 & 5.8 & 13 \\
\hline $13 C$ & $9-06-91$ & $09: 48$ & - & 12.3 & 7.3 & 833 & 5.4 & 12 \\
\hline $13 C$ & $11-13-91$ & $12: 09$ & - & 12.6 & 7.1 & 826 & 4.9 & 11 \\
\hline $13 C$ & $1-17-92$ & $12: 05$ & - & 12.6 & 7.1 & 822 & 4.9 & 13 \\
\hline $13 C$ & $3-18-92$ & $13: 29$ & -- & 13.1 & 7.1 & 818 & 6.8 & 11 \\
\hline $13 \mathrm{C}$ & $5-19-92$ & $19: 51$ & -- & 13.1 & 6.8 & 843 & 6.8 & 12 \\
\hline $13 C$ & $7-09-92$ & $17: 11$ & -- & 12.6 & 7.2 & 840 & 7.1 & 13 \\
\hline $13 \mathrm{C}$ & $9-16-92$ & $14: 00$ & -- & 13.0 & 7.1 & 812 & 6.7 & 12 \\
\hline $13 C$ & $11-19-92$ & $17: 09$ & - & 12.5 & 7.2 & 805 & 6.5 & 12 \\
\hline $13 C$ & $1-25-93$ & $14: 25$ & - & 12.6 & 7.1 & 815 & 6.9 & 12 \\
\hline $13 \mathrm{C}$ & $3-23-93$ & $14: 19$ & -- & 12.8 & 7.2 & 818 & 7.2 & 13 \\
\hline $13 \mathrm{C}$ & $5-18-93$ & $16: 41$ & - & 12.6 & 7.3 & 818 & 7.4 & 12 \\
\hline $13 \mathrm{C}$ & $7-13-93$ & $11: 44$ & - & 13.1 & 7.1 & 790 & 6.6 & 11 \\
\hline $13 C$ & $9-08-93$ & $11: 25$ & - & 12.3 & 7.1 & 780 & 6.8 & 10 \\
\hline 14 & $7-09-91$ & $11: 20$ & 45.15 & 14.6 & 7.3 & 643 & 10.2 & 2.4 \\
\hline 14 & $8-02-91$ & $17: 20$ & 45.90 & 13.9 & 7.1 & 653 & 6.2 & 1.9 \\
\hline 14 & $8-21-91$ & $17: 00$ & 45.95 & 13.9 & 7.0 & 652 & 6.1 & 2.1 \\
\hline 14 & $9-06-91$ & $11: 30$ & 47.95 & 13.9 & 7.2 & 654 & 6.0 & 2.3 \\
\hline 14 & $11-13-91$ & $13: 22$ & 51.27 & 13.8 & 7.1 & 663 & 6.0 & 2.4 \\
\hline 14 & $1-16-92$ & $17: 45$ & - & 13.5 & 7.0 & 655 & 5.4 & 3.1 \\
\hline 14 & $3-18-92$ & $9: 20$ & 51.50 & 13.9 & 7.0 & 706 & 7.1 & 2.7 \\
\hline 14 & $5-20-92$ & $15: 45$ & 51.58 & 14.2 & 7.0 & 837 & 7.1 & 2.2 \\
\hline 14 & $7-10-92$ & $12: 22$ & 51.73 & 14.0 & 6.9 & 653 & 7.5 & 2.8 \\
\hline 14 & $9-16-92$ & $14: 35$ & 46.00 & 14.1 & 7.0 & 643 & 7.7 & 2.3 \\
\hline 14 & $11-20-92$ & $10: 25$ & 47.32 & 13.6 & 7.0 & 642 & 7.4 & 2.8 \\
\hline 14 & $1-25-93$ & $15: 45$ & 49.60 & 13.4 & 7.1 & 645 & 7.5 & 3.1 \\
\hline 14 & $3-23-93$ & $15: 05$ & 48.83 & 13.7 & 7.2 & 649 & 7.7 & 3.4 \\
\hline 14 & $5-18-93$ & $17: 35$ & 46.32 & 13.8 & 7.2 & 652 & 8.0 & 3.0 \\
\hline 14 & $7-13-93$ & $10: 05$ & 42.85 & 14.3 & 7.1 & 673 & 7.8 & 2.9 \\
\hline 14 & $9-08-93$ & $08: 50$ & 42.92 & 14.3 & 7.0 & 669 & 7.3 & 1.8 \\
\hline 10 & $7-10-91$ & $11: 40$ & 15.15 & 15.0 & 7.1 & 1,120 & 2.2 & 19 \\
\hline 15 & $7-31-91$ & $16: 30$ & 14.80 & 14.3 & 8.4 & 1,180 & .1 & 24 \\
\hline 15 & $8-20-91$ & $11: 52$ & 14.40 & 14.1 & 7.1 & 1,180 & .4 & 27 \\
\hline 15 & $9-06-91$ & $12: 50$ & 16.30 & 14.2 & 7.2 & 1,180 & .4 & 30 \\
\hline 15 & $11-13-91$ & $14: 08$ & 17.22 & 14.6 & 7.0 & 1,170 & .4 & 24 \\
\hline 15 & $1-17-92$ & $14: 45$ & -- & 14.6 & 7.0 & 1,110 & 0.5 & 22 \\
\hline 15 & $3-18-92$ & $12: 05$ & 15.62 & 14.6 & 7.0 & 1,090 & .4 & 18 \\
\hline 15 & $5-20-92$ & $14: 53$ & 16.96 & 14.8 & 7.0 & 1,140 & .3 & 22 \\
\hline 15 & $7-10-92$ & $10: 20$ & 16.61 & 14.2 & 6.8 & 1,100 & .4 & 20 \\
\hline
\end{tabular}


Tabie 11. Water-quality data for samples from 20 monitoring wells in the study area, Nuckolls County, Nebraska, 1991-93 - Continued

[--, no data; ${ }^{\circ} \mathrm{C}$, degrees Celsius; $\mathrm{mg} / \mathrm{L}$, milligrams per liter; $\mu \mathrm{S} / \mathrm{cm}$, microsiemens per centimeter]

\begin{tabular}{|c|c|c|c|c|c|c|c|c|}
\hline $\begin{array}{c}\text { Well } \\
\text { number }\end{array}$ & Date & Time & $\begin{array}{l}\text { Depth to } \\
\text { water } \\
\text { (feet) }\end{array}$ & $\begin{array}{c}\text { Tempera- } \\
\text { ture } \\
\left({ }^{\circ} \mathrm{C}\right)\end{array}$ & $\begin{array}{c}\text { pH } \\
\text { (standard } \\
\text { units) }\end{array}$ & $\begin{array}{c}\text { Speciflc } \\
\text { conductance } \\
(\mu \mathrm{S} / \mathrm{cm} \text { at } \\
\left.25^{\circ} \mathrm{C}\right)\end{array}$ & $\begin{array}{l}\text { Dissolved } \\
\text { oxygen } \\
\text { (mg/L) }\end{array}$ & $\begin{array}{c}\text { Nitrate } \\
\text { as } \\
\text { nitrogen } \\
\text { (mg/L) }\end{array}$ \\
\hline 15 & $9-16-92$ & $11: 05$ & 16.70 & 14.7 & 7.0 & 1,250 & .2 & 32 \\
\hline 15 & $11-20-92$ & $12: 03$ & 16.39 & 14.6 & 6.9 & 1,240 & .4 & 34 \\
\hline 15 & $1-27-93$ & $14: 15$ & 16.50 & 14.7 & 6.9 & 1,230 & .3 & 28 \\
\hline 15 & $3-24-93$ & $15: 53$ & 15.95 & 14.6 & 7.0 & 1,210 & .2 & 25 \\
\hline 15 & $5-19-93$ & $9: 45$ & 17.29 & 13.8 & 7.0 & 1,200 & .6 & 25 \\
\hline 15 & $7-13-93$ & $9: 25$ & 11.50 & 13.7 & 7.1 & 1,270 & .3 & 31 \\
\hline 15 & $9-08-93$ & $10: 05$ & 14.21 & 13.3 & 7.0 & 1,330 & 1.0 & 37 \\
\hline 16 & $7-10-91$ & $10: 35$ & 7.60 & 13.2 & 7.3 & 941 & 1.2 & .70 \\
\hline 16 & $7-31-91$ & $15: 05$ & 7.40 & 12.7 & 7.8 & 980 & .1 & .70 \\
\hline 16 & $8-20-91$ & 9:04 & 8.07 & 13.0 & 7.3 & 946 & .2 & .10 \\
\hline 16 & $9-06-91$ & $14: 35$ & 8.70 & 13.2 & 7.2 & 953 & .3 & .30 \\
\hline 16 & $11-13-91$ & $14: 43$ & 9.40 & 13.8 & 7.2 & 975 & .2 & .20 \\
\hline 16 & $1-17-92$ & $14: 15$ & - & 13.5 & 7.2 & 949 & .2 & .40 \\
\hline 16 & $3-18-92$ & $11: 00$ & 8.52 & 13.5 & 7.1 & 984 & .5 & .30 \\
\hline 16 & $5-20-92$ & $14: 12$ & 8.54 & 13.5 & 7.0 & 1,000 & .2 & .50 \\
\hline 16 & $7-10-92$ & $11: 10$ & 8.69 & 13.3 & 7.1 & 989 & .4 & .40 \\
\hline 16 & $9-16-92$ & $15: 53$ & 7.80 & 13.5 & 7.0 & 978 & .2 & .30 \\
\hline 16 & $11-20-92$ & $11: 21$ & 7.82 & 13.5 & 7.0 & 968 & .5 & .30 \\
\hline 16 & $1-25-93$ & $16: 29$ & 7.70 & 13.0 & 7.1 & 978 & .5 & .30 \\
\hline 16 & $3-24-93$ & $16: 29$ & 5.51 & 12.6 & 7.1 & 974 & .3 & .30 \\
\hline 16 & $5-19-93$ & $9: 00$ & 5.93 & 12.2 & 7.2 & 970 & .2 & .20 \\
\hline 16 & $7-14-93$ & $8: 53$ & 4.31 & 12.5 & 7.23 & 969 & .2 & .10 \\
\hline 16 & $9-08-93$ & $9: 30$ & 6.28 & 13.0 & 7.1 & 990 & .5 & .50 \\
\hline
\end{tabular}

${ }^{1}$ Well inaccessible. 
Table 12. Nitrate and ammonium concentrations as nitrogen in sediment cores for site 1 in the study area, Nuckolls County, Nebraska, spring 1991

$[-$, no data; mg/kg, milligrams per kilogram $]$

\begin{tabular}{|c|c|c|c|c|c|c|}
\hline \multirow{2}{*}{$\begin{array}{l}\text { Sample depth } \\
\text { (foet) }\end{array}$} & \multicolumn{3}{|c|}{$\begin{array}{l}\text { Nitrate as niltrogen } \\
(\mathrm{mg} / \mathrm{kg})\end{array}$} & \multicolumn{3}{|c|}{$\begin{array}{c}\text { Ammonlum as nitrogen } \\
(\mathrm{mg} / \mathrm{kg})\end{array}$} \\
\hline & Core 1 & Core 2 & Mean & Core 1 & Core 2 & Mean \\
\hline 0.3 & - & -- & -- & 2.19 & 2.38 & 2.29 \\
\hline 3.0 & 1.85 & 2.11 & 1.98 & 1.83 & 1.64 & 1.74 \\
\hline 6.4 & 1.39 & 2.06 & 1.73 & 1.33 & 2.26 & 1.80 \\
\hline 9.4 & - & 2.16 & 2.16 & -- & 1.95 & 1.95 \\
\hline 11.4 & 2.47 & 2.63 & 2.55 & 2.44 & 1.27 & 1.86 \\
\hline 13 & 2.83 & 2.32 & 2.58 & 1.33 & 1.52 & 1.43 \\
\hline 16 & 2.16 & 2.68 & 2.42 & 1.58 & 1.64 & 1.61 \\
\hline 19 & 2.01 & 2.27 & 2.14 & 1.70 & 3.55 & 2.63 \\
\hline 22 & 2.01 & 2.37 & 2.19 & 3.12 & 2.01 & 2.57 \\
\hline 25 & 1.75 & 2.16 & 1.96 & 2.38 & 2.13 & 2.26 \\
\hline 28 & 1.24 & 1.49 & 1.37 & 2.75 & 3.18 & 2.97 \\
\hline 31 & 1.65 & 1.70 & 1.68 & 3.92 & 2.32 & 3.12 \\
\hline 34 & 1.96 & 1.91 & 1.94 & 4.11 & 3.00 & 3.56 \\
\hline 37 & 2.22 & 2.22 & 2.22 & 3.61 & 2.93 & 3.27 \\
\hline 40.6 & 2.37 & 1.13 & 1.75 & 3.12 & 1.95 & 2.54 \\
\hline 43.8 & 2.47 & 1.60 & 2.04 & 3.43 & 2.75 & 3.09 \\
\hline 46 & 2.63 & 1.55 & 2.09 & 3.18 & 2.19 & 2.67 \\
\hline 49 & 2.47 & 1.49 & 1.98 & 2.75 & 2.44 & 2.60 \\
\hline 51.3 & 1.49 & 1.49 & 1.49 & 2.93 & 2.44 & 2.69 \\
\hline 52 & - & 1.29 & 1.29 & -- & 3.00 & 3.00 \\
\hline 55 & 2.27 & 1.13 & 1.70 & 2.44 & 3.06 & 2.75 \\
\hline 56 & 1.80 & 1.03 & 1.42 & 3.06 & 3.98 & 3.52 \\
\hline 58 & 1.85 & 0.98 & 1.42 & 1.64 & 1.95 & 1.80 \\
\hline 61.5 & - & 1.24 & 1.24 & -- & 4.17 & 4.17 \\
\hline 62 & -- & 2.06 & 2.06 & -- & 5.21 & 5.21 \\
\hline 64 & 2.37 & 1.49 & 1.93 & 5.03 & 3.86 & 4.45 \\
\hline 65 & 2.11 & 1.24 & 1.68 & 5.34 & 4.54 & 4.94 \\
\hline 67 & 1.75 & - & 1.75 & 3.00 & -- & 3.00 \\
\hline 68 & - & 1.24 & 1.24 & -- & 2.32 & 2.32 \\
\hline 70 & 1.24 & 1.34 & 1.29 & 2.07 & 2.19 & 2.13 \\
\hline 73 & 1.34 & -- & 1.34 & 2.63 & - & 2.63 \\
\hline
\end{tabular}


Table 13. Nitrate and ammonium concentrations as nitrogen and organic-matter content in sediment cores for site 1 in the study area, Nuckolls County, Nebraska, spring 1992

[mg/kg, milligrams per kilogram; --, no data]

\begin{tabular}{|c|c|c|c|c|c|c|c|c|c|c|c|c|}
\hline \multirow{2}{*}{$\begin{array}{l}\text { Samplo } \\
\text { depth } \\
\text { (feet) }\end{array}$} & \multicolumn{4}{|c|}{$\begin{array}{c}\text { Nitrate as nitrogen } \\
(\mathbf{m g} / \mathrm{kg})\end{array}$} & \multicolumn{4}{|c|}{$\begin{array}{c}\text { Ammonium as nitrogen } \\
(\mathrm{mg} / \mathrm{kg})\end{array}$} & \multicolumn{4}{|c|}{$\begin{array}{l}\text { Organic matter } \\
\text { (percent) }\end{array}$} \\
\hline & Core 1 & Core 2 & Core 3 & Wean & Core 1 & Core 2 & Core 3 & Mean & Core 1 & Core 2 & Core 3 & Mean \\
\hline$\overline{0.3}$ & 3.08 & 2.03 & 1.96 & 2.36 & 2.30 & 1.36 & 1.28 & 1.65 & 2.13 & 2.37 & 2.34 & 2.28 \\
\hline 3.0 & 3.81 & 4.02 & 4.42 & 4.08 & 1.00 & 1.00 & 1.94 & 1.31 & .42 & .31 & .39 & .37 \\
\hline 6.0 & 2.24 & 1.03 & .83 & 1.37 & .83 & 2.19 & 1.18 & 1.40 & .20 & .17 & .22 & .20 \\
\hline 9.0 & 2.19 & 1.03 & .88 & 1.37 & .41 & .62 & .87 & .63 & .22 & .22 & .22 & .22 \\
\hline 11.4 & 3.03 & 1.50 & 1.50 & 2.01 & .77 & .59 & .32 & .56 & 1.12 & 1.09 & 1.12 & 1.11 \\
\hline 13.0 & 2.45 & 1.64 & 1.70 & 1.93 & 1.00 & .74 & 5.7 & .77 & 1.05 & 1.05 & .88 & .99 \\
\hline 16.0 & 2.13 & 1.14 & 1.29 & 1.52 & .41 & 1.24 & 9.7 & .87 & .37 & .37 & .42 & .39 \\
\hline 19.0 & 2.19 & .61 & 1.19 & 1.33 & 1.12 & 1.30 & 1.08 & 1.17 & .17 & .15 & .16 & .16 \\
\hline 22.0 & 1.61 & .74 & 1.40 & 1.25 & 1.54 & 1.45 & 1.58 & 1.52 & .15 & .15 & .13 & .14 \\
\hline 25.0 & 2.24 & 1.24 & 1.86 & 1.78 & 1.48 & 1.65 & 2.34 & 1.82 & .15 & .15 & .17 & .16 \\
\hline 28.0 & 1.45 & 1.27 & 2.32 & 1.68 & 1.89 & 1.21 & 1.43 & 1.51 & .18 & .19 & .17 & .18 \\
\hline 31.0 & 1.08 & .98 & 1.55 & 1.20 & 2.01 & 1.36 & 1.38 & 1.58 & .12 & .07 & .13 & .10 \\
\hline 34.0 & 1.45 & 1.27 & 1.19 & 1.30 & 1.65 & 1.86 & 3.46 & 2.32 & .09 & .11 & .15 & .12 \\
\hline 37.0 & 1.29 & 1.29 & 1.50 & 1.36 & 1.00 & 1.77 & 2.55 & 1.77 & .02 & .12 & .15 & .10 \\
\hline 41.0 & 1.19 & 1.35 & .73 & 1.09 & 1.83 & 1.42 & 1.84 & 1.70 & .07 & .07 & .07 & .07 \\
\hline 43.0 & 1.77 & 1.27 & 1.50 & 1.51 & 1.65 & 1.54 & 2.04 & 1.74 & .11 & .07 & .09 & .09 \\
\hline 46.0 & - & 1.61 & .88 & .83 & 2.01 & 1.77 & 2.29 & 2.02 & .20 & .11 & .12 & .14 \\
\hline 49.0 & 2.34 & 1.56 & .94 & 1.61 & 2.60 & 2.30 & 2.44 & 2.45 & .13 & .15 & .10 & .13 \\
\hline 51.3 & 1.45 & 1.03 & .99 & 1.15 & 2.30 & 2.30 & 3.20 & 2.60 & .09 & .11 & .07 & .09 \\
\hline 52.0 & 1.29 & .93 & .58 & .93 & 1.77 & 2.83 & 2.44 & 2.35 & .13 & .12 & .09 & .11 \\
\hline 55.0 & 1.35 & .93 & 1.19 & 1.16 & 2.95 & 3.72 & 2.70 & 3.12 & .12 & .11 & .12 & .11 \\
\hline 56.0 & 1.08 & 1.19 & 1.19 & 1.15 & 2.48 & 3.75 & 3.41 & 3.21 & .15 & .16 & .15 & .15 \\
\hline 58.0 & 1.40 & 1.08 & 1.45 & 1.31 & 3.01 & 2.83 & 3.15 & 3.00 & .13 & .15 & .11 & .13 \\
\hline 62.0 & 1.29 & .77 & .68 & .91 & 3.48 & 3.66 & 1.99 & 3.04 & .15 & .17 & .04 & .12 \\
\hline 64.0 & .51 & .61 & .99 & .70 & 3.07 & 4.61 & 3.46 & 3.71 & .07 & .13 & .07 & .09 \\
\hline 65.0 & .40 & .56 & 1.14 & .70 & 2.13 & 3.49 & 3.26 & 2.96 & .07 & .08 & .07 & .07 \\
\hline 68.0 & .61 & .56 & .42 & .53 & 3.54 & 3.19 & 3.87 & 3.53 & .18 & .29 & .22 & .23 \\
\hline 70.0 & .51 & .14 & .88 & .51 & 2.42 & 1.48 & 2.60 & 2.17 & .04 & .06 & .06 & .05 \\
\hline 73.0 & .14 & .40 & 1.04 & .53 & 1.30 & 1.24 & 2.04 & 1.53 & .02 & .04 & .05 & .04 \\
\hline
\end{tabular}


Table 14. Nitrate and ammonium concentrations as nitrogen and organic-matter content in sediment cores for site 1 in the study area, Nuckolls County, Nebraska, spring 1993

[-, no data; $\mathrm{mg} / \mathbf{k g}$, milligrams per kilogram $]$

\begin{tabular}{|c|c|c|c|c|c|c|c|c|c|c|c|c|}
\hline \multirow{2}{*}{$\begin{array}{l}\text { Sam- } \\
\text { ple } \\
\text { depth } \\
\text { (feet) }\end{array}$} & \multicolumn{4}{|c|}{$\begin{array}{c}\text { Nitrate as niftrogen } \\
(\mathrm{mg} / \mathrm{kg})\end{array}$} & \multicolumn{4}{|c|}{$\begin{array}{c}\text { Ammonium as nitrogen } \\
(\mathrm{mg} / \mathrm{kg})\end{array}$} & \multicolumn{4}{|c|}{$\begin{array}{l}\text { Organlc matter } \\
\text { (percent) }\end{array}$} \\
\hline & Core 1 & Core 2 & Core 3 & Mean & Core 1 & Core 2 & Core 3 & Mean & Core 1 & Core 2 & Core 3 & Mean \\
\hline 0.3 & 1.91 & 2.87 & 2.06 & 2.28 & 2.41 & 1.66 & 1.72 & 1.93 & 0.29 & 1.93 & 2.09 & 1.44 \\
\hline 3.0 & 2.32 & 2.06 & 5.70 & 3.36 & 1.92 & 2.30 & 1.54 & 1.92 & 1.77 & .47 & .47 & .90 \\
\hline 6.0 & 3.11 & 3.45 & 5.87 & 4.14 & 1.54 & 2.06 & 1.98 & 1.86 & .20 & .20 & .23 & .21 \\
\hline 9.0 & 1.91 & 2.01 & 1.82 & 1.91 & 1.08 & 1.58 & 1.25 & 1.30 & .97 & .19 & .22 & .46 \\
\hline 11.4 & 2.68 & 2.01 & 2.25 & 2.31 & 8.50 & 1.83 & 1.02 & 3.78 & .39 & .76 & .59 & .58 \\
\hline 13.0 & 1.68 & 1.96 & 1.68 & 1.77 & 1.14 & 1.19 & 1.19 & 1.17 & .22 & 1.20 & 1.05 & .82 \\
\hline 16.0 & 1.37 & 1.24 & 1.20 & 1.27 & 1.31 & 1.31 & 1.72 & 1.45 & .28 & .42 & .39 & .36 \\
\hline 19.0 & 1.77 & 1.25 & 1.01 & 1.34 & 2.06 & 1.57 & 2.06 & 1.90 & .28 & .19 & .20 & .22 \\
\hline 22.0 & 1.77 & 1.10 & .88 & 1.25 & 2.06 & 1.83 & 2.71 & 2.20 & .15 & .17 & .16 & .16 \\
\hline 25.0 & 1.77 & 1.01 & .96 & 1.25 & 1.66 & 2.76 & 3.17 & 2.53 & .15 & .15 & .15 & .15 \\
\hline 28.0 & 2.01 & 1.10 & 1.10 & 1.40 & .91 & 1.31 & 2.76 & 1.66 & .17 & .15 & .15 & .16 \\
\hline 31.0 & 1.91 & 1.25 & 1.24 & 1.47 & 2.24 & 2.07 & 2.73 & 2.35 & .12 & .13 & .12 & .12 \\
\hline 34.0 & 1.82 & 1.48 & 1.58 & 1.63 & 1.83 & 1.60 & 3.34 & 2.26 & .09 & .07 & .13 & .10 \\
\hline 37.0 & -- & -. & 2.49 & 2.49 & -- & -- & 2.47 & 2.47 & -- & -- & .07 & .07 \\
\hline 41.0 & 1.68 & .77 & 2.12 & 1.52 & 3.17 & 2.01 & 3.53 & 2.90 & .07 & .11 & .09 & .09 \\
\hline 43.0 & 2.01 & .81 & 2.71 & 1.84 & 2.01 & 2.41 & 3.36 & 2.59 & .09 & .11 & .15 & .12 \\
\hline 46.0 & 1.87 & .43 & 2.17 & 1.49 & 2.12 & 2.30 & 5.86 & 3.43 & .07 & .15 & .15 & .12 \\
\hline 49.0 & 2.01 & .29 & 2.02 & 1.44 & 3.28 & 3.17 & 3.64 & 3.36 & .07 & .13 & .09 & .10 \\
\hline 51.3 & 1.48 & 1.48 & 2.31 & 1.76 & 2.53 & 2.35 & 5.12 & 3.33 & .11 & .09 & .15 & .12 \\
\hline 52.0 & 1.58 & 1.05 & 2.02 & 1.55 & 1.54 & 2.93 & 5.69 & 3.39 & .07 & .412 & .16 & .12 \\
\hline 55.0 & 1.82 & .67 & 2.27 & 1.59 & 1.78 & 2.64 & 6.20 & 3.54 & .15 & .15 & .17 & .16 \\
\hline 56.0 & 1.72 & .81 & 2.36 & 1.63 & 2.47 & 4.09 & 5.18 & 3.91 & .15 & .20 & .16 & .17 \\
\hline 58.0 & 1.77 & .67 & 1.97 & 1.47 & 2.76 & 4.27 & 2.40 & 3.14 & .15 & .17 & .04 & .12 \\
\hline 62.0 & 1.63 & .62 & 2.17 & 1.47 & 2.91 & 4.73 & 3.64 & 3.76 & .16 & .18 & .09 & .14 \\
\hline 64.0 & 1.58 & .10 & 1.09 & .92 & 2.41 & 3.75 & 3.70 & 3.29 & .12 & .07 & .09 & .09 \\
\hline 65.0 & 1.68 & -- & 1.04 & 1.36 & 2.70 & -- & 3.36 & 3.03 & .09 & -- & .14 & .12 \\
\hline 68.0 & 2.01 & - & .99 & 1.50 & 3.05 & -. & 4.61 & 3.83 & .15 & -- & .10 & .13 \\
\hline 70.0 & 1.48 & -- & -- & 1.48 & 3.22 & -- & - & 3.22 & .07 & -- & -- & .07 \\
\hline 73.0 & 1.58 & -- & -- & 1.58 & 4.44 & -- & -- & 4.44 & .11 & -- & -- & .11 \\
\hline
\end{tabular}




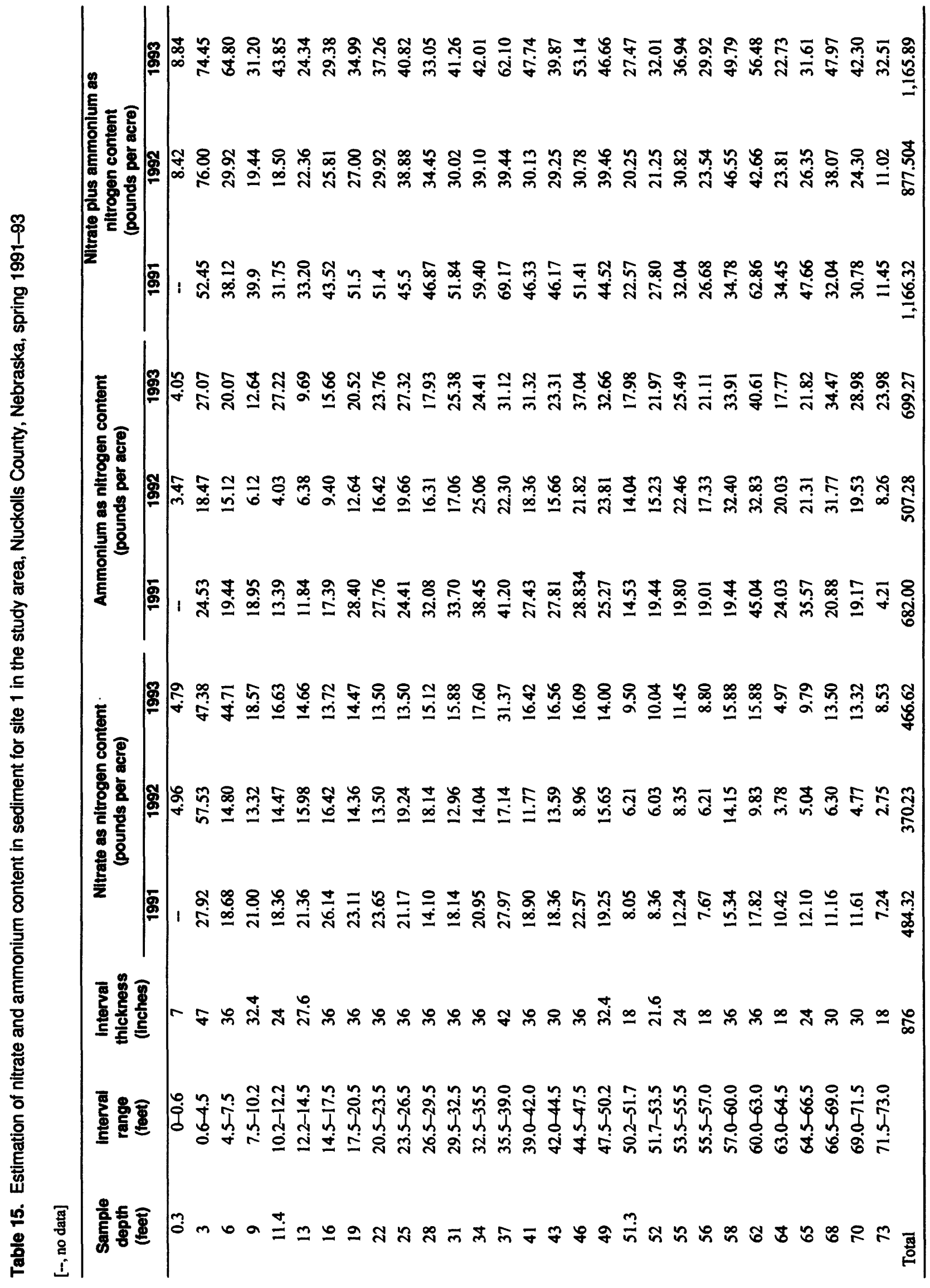


Table 16. Nitrate and ammonium concentrations as nitrogen in sediment cores for site 9 in the study area, Nuckolls County, Nebraska, spring 1991

\begin{tabular}{|c|c|c|c|c|c|c|}
\hline \multirow{2}{*}{$\begin{array}{l}\text { Sample depth } \\
\text { (feet) }\end{array}$} & \multicolumn{3}{|c|}{$\begin{array}{c}\text { Nitrate as nitrogen } \\
\text { (milligrams per kllogram) }\end{array}$} & \multicolumn{3}{|c|}{$\begin{array}{l}\text { Ammonium as nlitrogen } \\
\text { (milligrams per kllogram) }\end{array}$} \\
\hline & Core 1 & Core 2 & Mean & Core 1 & Core 2 & Mean \\
\hline$\overline{0.3}$ & 3.92 & 7.07 & 5.50 & 2.26 & 2.08 & 2.17 \\
\hline 2.0 & 1.65 & 1.91 & 1.78 & 2.13 & 2.81 & 2.47 \\
\hline 3.0 & 1.13 & 1.39 & 1.26 & 2.19 & 2.87 & 2.53 \\
\hline 5.0 & 4.23 & 1.39 & 2.81 & 1.61 & 1.02 & 1.32 \\
\hline 7.0 & 11.50 & 1.60 & 6.65 & 1.21 & 1.24 & 1.23 \\
\hline 9.0 & 13.90 & 2.89 & 8.40 & 2.93 & 1.27 & 2.10 \\
\hline 11.0 & 11.80 & 8.56 & 9.78 & 2.04 & 1.46 & 1.75 \\
\hline 13.0 & 4.74 & 5.26 & 5.00 & 1.21 & 1.49 & 1.35 \\
\hline 15.0 & 3.23 & 2.04 & 2.64 & 2.01 & 2.54 & 2.28 \\
\hline 17.0 & 3.09 & 1.81 & 2.45 & 2.32 & 1.83 & 2.08 \\
\hline 18.6 & 2.73 & 1.91 & 2.32 & 1.58 & 1.64 & 1.61 \\
\hline 19.0 & 2.58 & 1.49 & 2.04 & 1.31 & 0.90 & 1.11 \\
\hline
\end{tabular}

Table 17. Nitrate and ammonium concentrations as nitrogen and organic-matter content in sediment cores for site 9 in the study area, Nuckolls County, Nebraska, spring 1992

\begin{tabular}{|c|c|c|c|c|c|c|c|c|c|c|c|c|}
\hline \multirow{2}{*}{$\begin{array}{l}\text { Sample } \\
\text { depth } \\
\text { (feet) }\end{array}$} & \multicolumn{4}{|c|}{$\begin{array}{c}\text { Nitrate as niltrogen } \\
\text { (milligrams per kilogram) }\end{array}$} & \multicolumn{4}{|c|}{$\begin{array}{l}\text { Ammonlum as nitrogen } \\
\text { (milligrams per kllogram) }\end{array}$} & \multicolumn{4}{|c|}{$\begin{array}{l}\text { Organlc-matter content } \\
\text { (percent) }\end{array}$} \\
\hline & Core 1 & Core 2 & Core 3 & Mean & Core 1 & Core 2 & Core 3 & Mean & Core 1 & Core 2 & Core 3 & Thean \\
\hline 0.3 & 2.93 & 2.01 & 3.70 & 2.88 & 2.29 & .97 & 1.94 & 1.73 & 1.76 & 1.76 & 2.30 & 1.94 \\
\hline 2.0 & 1.65 & 1.88 & 2.11 & 1.88 & 2.70 & 1.99 & 1.73 & 2.14 & 1.05 & .98 & 1.11 & 1.05 \\
\hline 3.0 & 1.19 & .94 & 1.60 & 1.24 & 2.60 & 1.33 & 2.80 & 2.24 & .57 & .44 & .44 & .48 \\
\hline 5.0 & .63 & 1.32 & 1.29 & 1.08 & 1.33 & 1.63 & 1.84 & 1.60 & .57 & .44 & .50 & .50 \\
\hline 7.0 & .88 & .88 & 1.91 & 1.22 & 2.19 & 1.89 & 1.63 & 1.40 & .55 & .57 & .51 & .54 \\
\hline 9.0 & 1.14 & 1.12 & 1.91 & 1.39 & .62 & 1.71 & 2.19 & 1.51 & .22 & .29 & .25 & .25 \\
\hline 11.0 & 1.29 & 1.96 & 2.47 & 1.91 & .57 & 1.48 & 2.55 & 1.53 & .22 & .22 & .18 & .21 \\
\hline 13.0 & .73 & 1.58 & 1.91 & 1.41 & 1.38 & 1.36 & 1.73 & 1.49 & .18 & .22 & .25 & .22 \\
\hline 15.0 & .73 & 1.81 & 2.06 & 1.53 & .32 & 1.20 & 2.24 & 1.25 & .22 & .14 & .17 & .18 \\
\hline 17.0 & 1.45 & 2.42 & 1.19 & 1.69 & .42 & 1.36 & 2.09 & 1.29 & .42 & .22 & .29 & .31 \\
\hline 18.6 & 1.35 & 2.57 & 1.29 & 2.19 & .92 & 1.94 & 1.73 & 1.53 & .44 & .44 & .35 & .41 \\
\hline 19.0 & 1.70 & 2.32 & 1.19 & 1.74 & .92 & 1.43 & .32 & .89 & .44 & .44 & .51 & .46 \\
\hline 20.0 & 1.70 & 2.47 & .97 & 1.71 & .97 & 1.23 & 1.13 & 1.11 & .44 & .37 & .44 & .42 \\
\hline
\end{tabular}



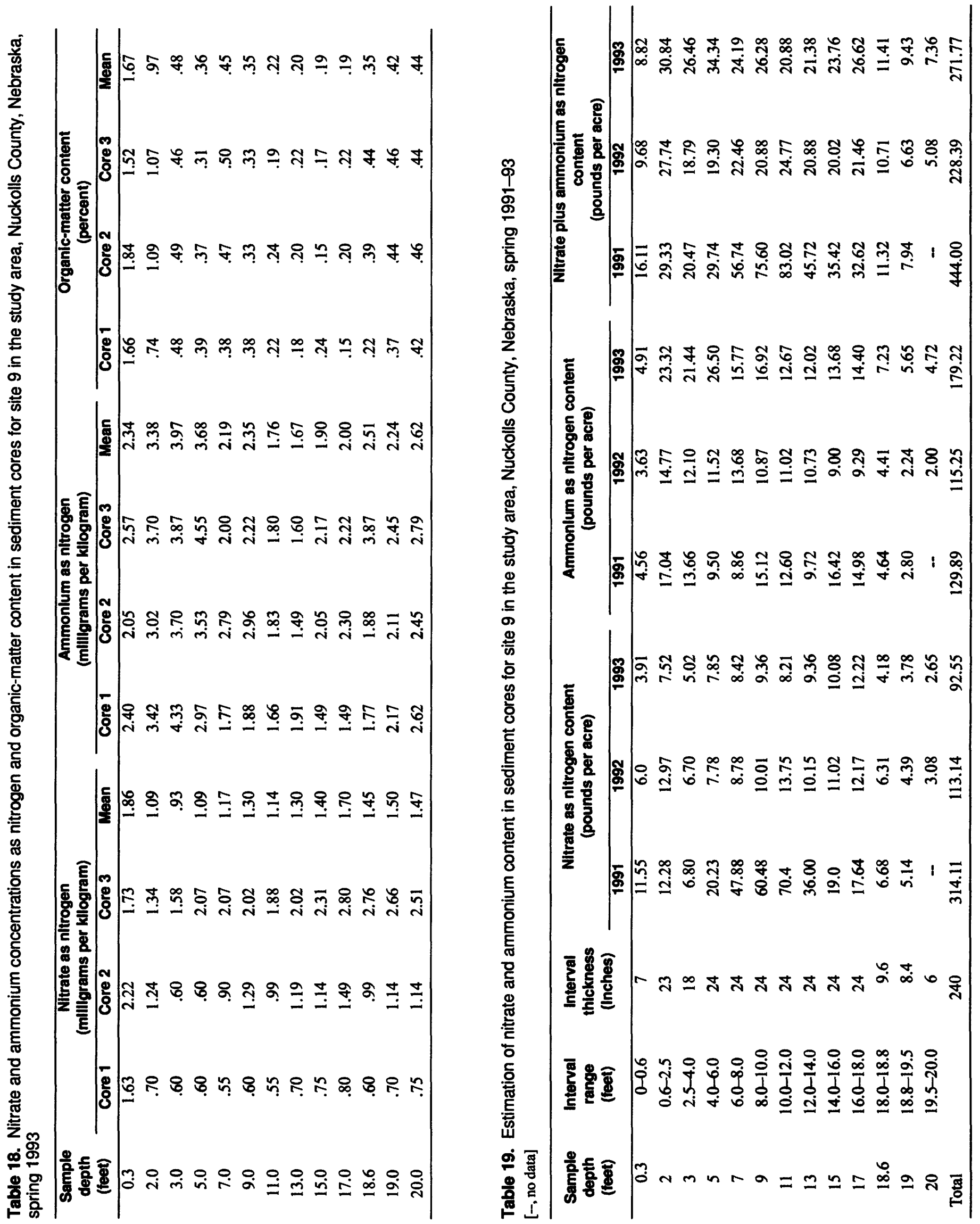


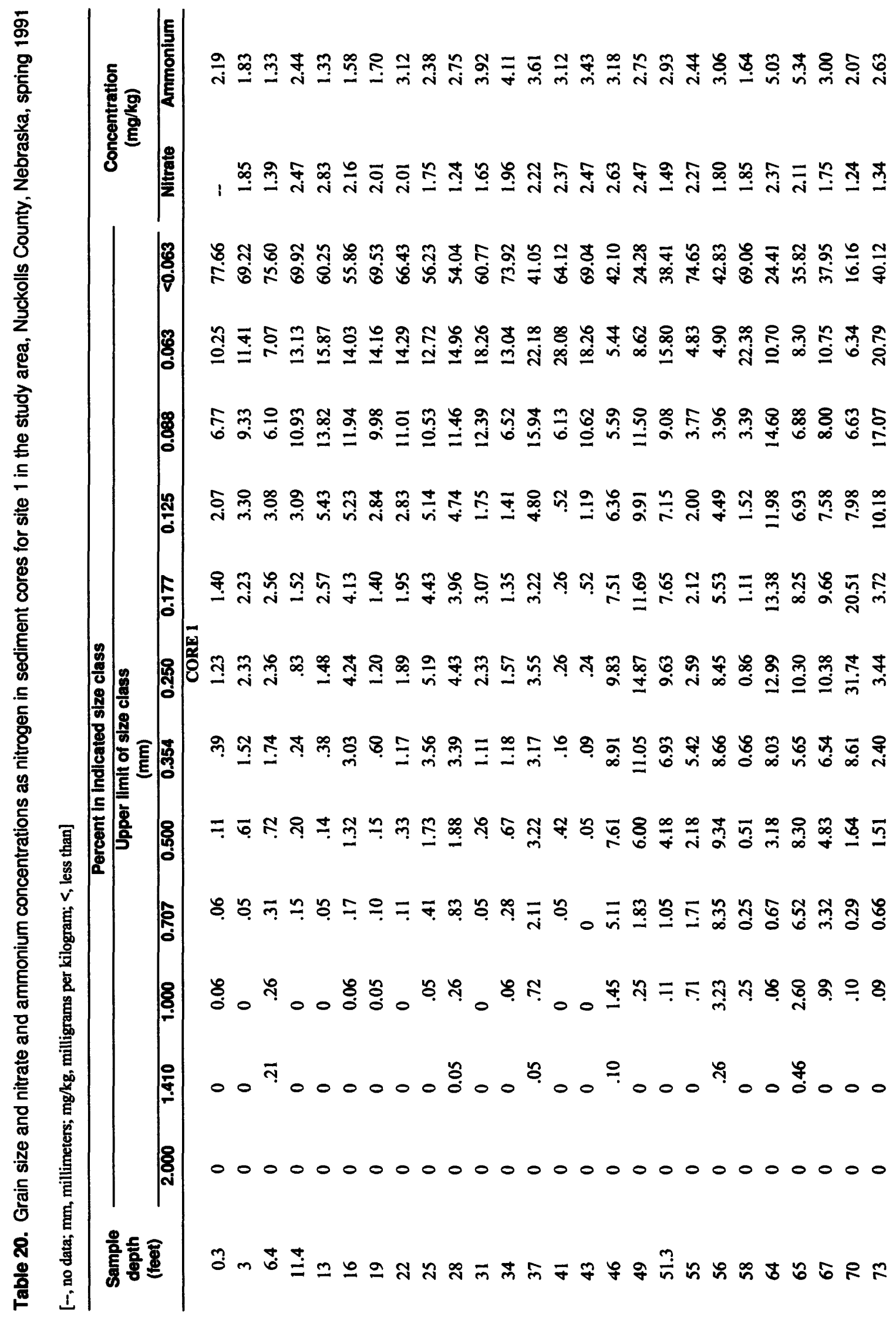

52 Distribution of Selected Nitrogen Compounds In Ground Water and the Unsaturated Zone, Superlor-Hardy Special Protection Area, Nuckolls County, Nobraska, 1991-93 







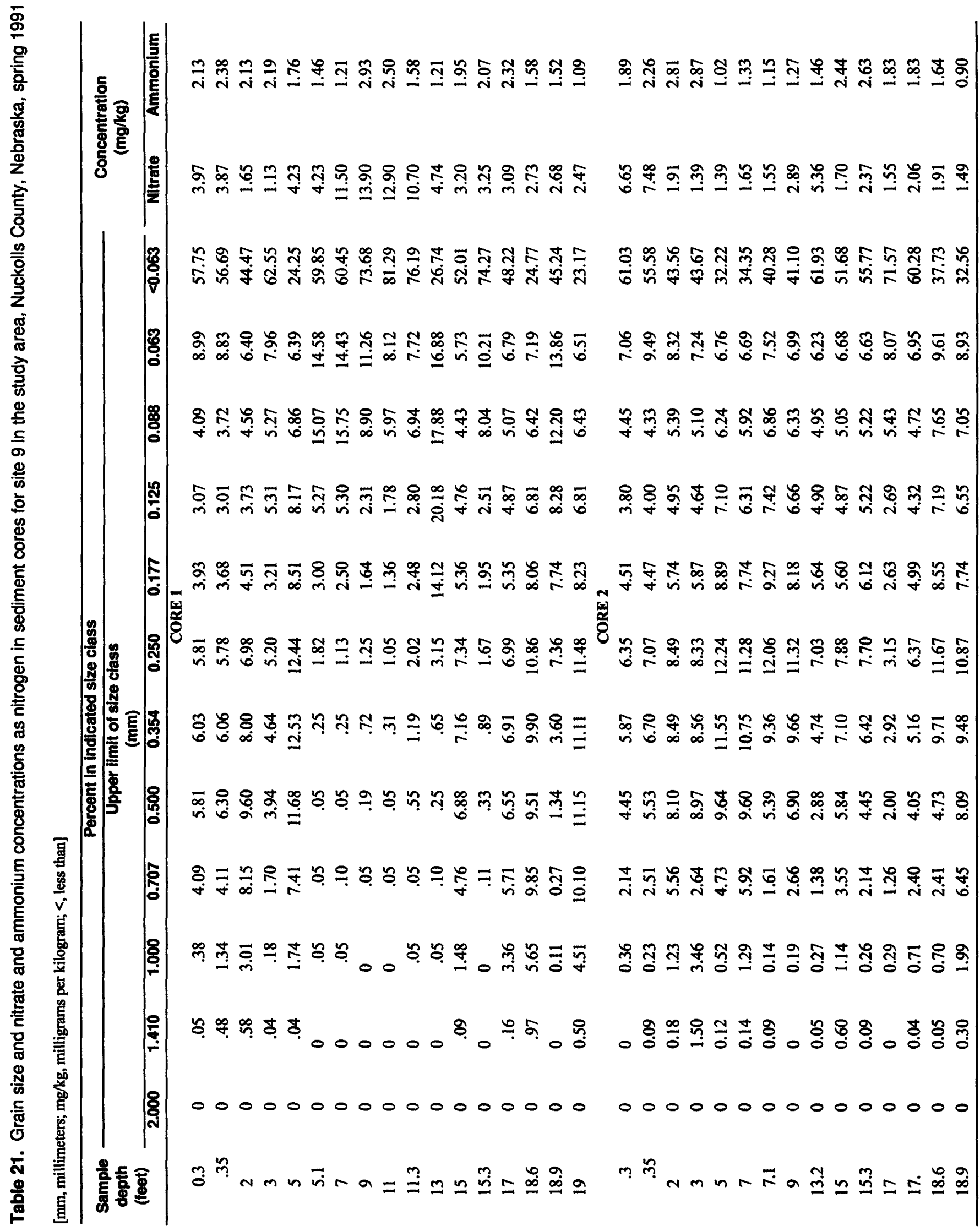

54 Distribution of Selected Nitrogen Compounds in Ground Water and the Unsaturated Zone, Superlor-Hardy Special Protection Area, Nuckoils County, Nebraska, 1991-93 